
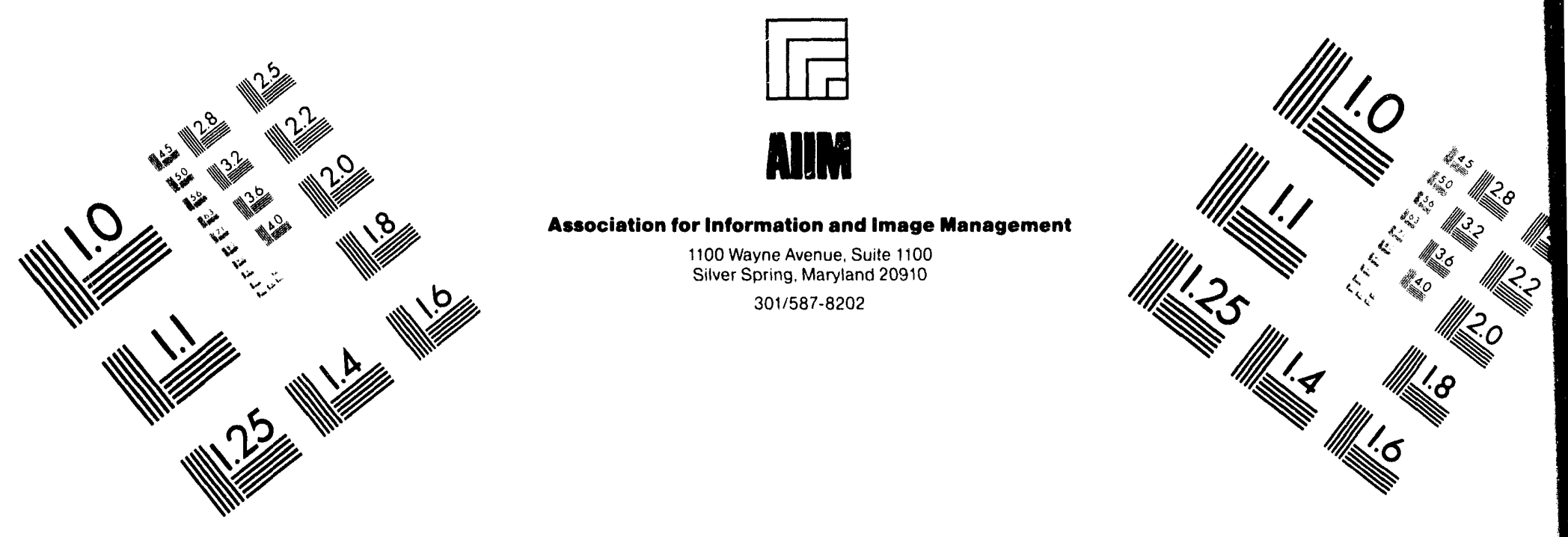

\title{
Centimeter
}

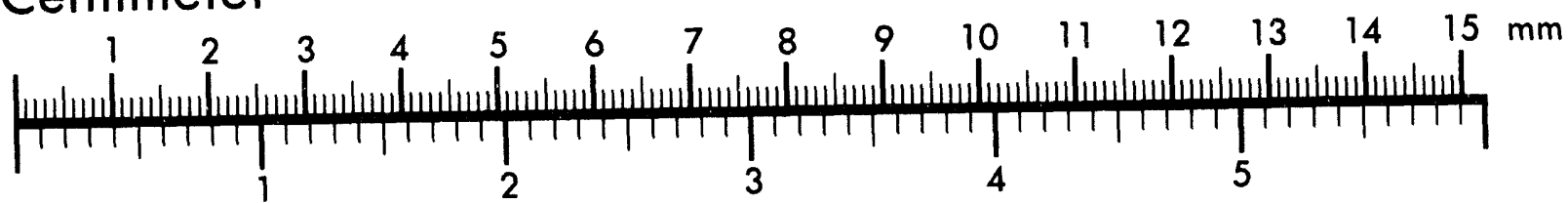

Inches
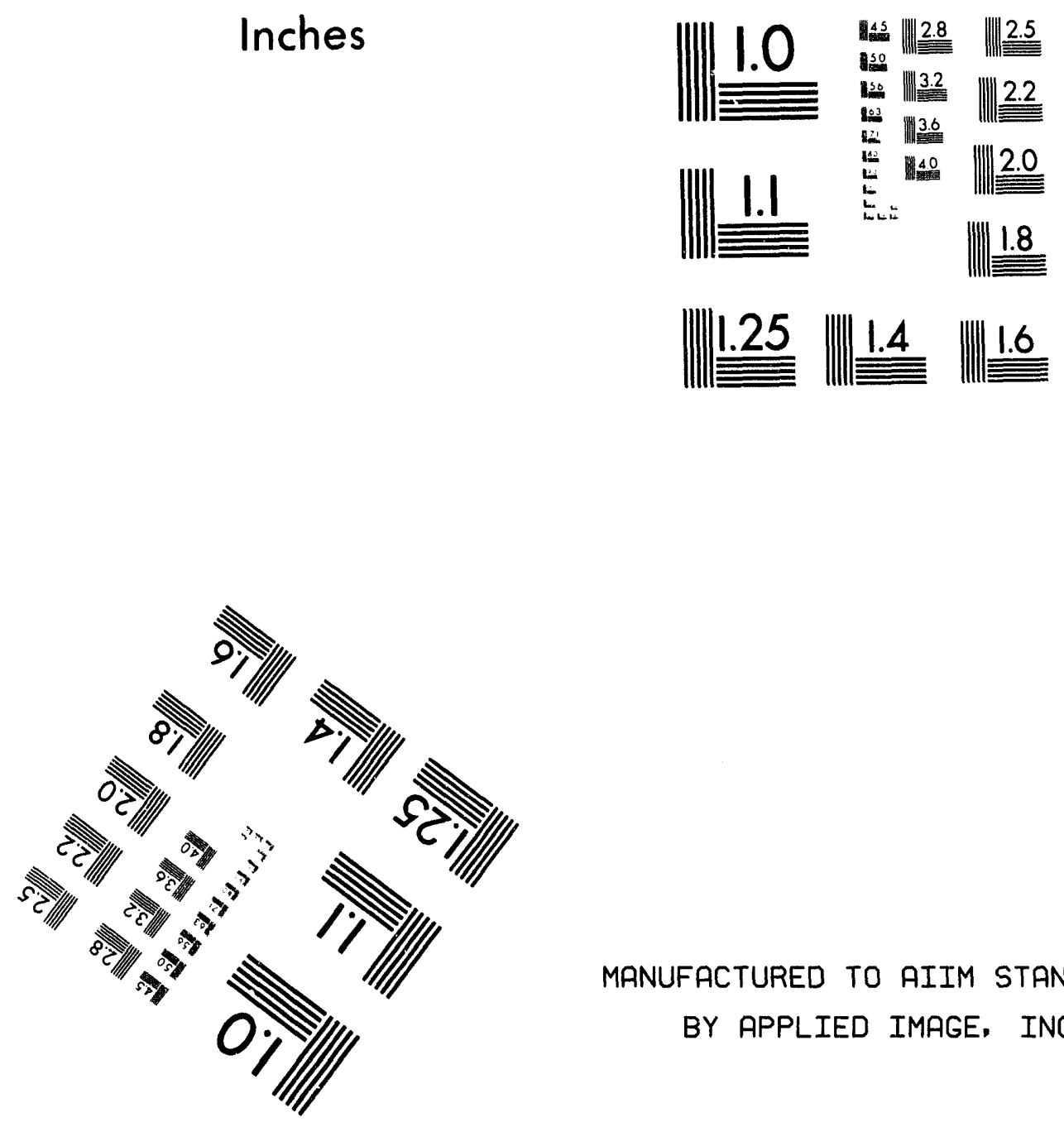

MANUFACTURED TO AIIM STANDARDS

BY APPLIED IMAGE, INC.

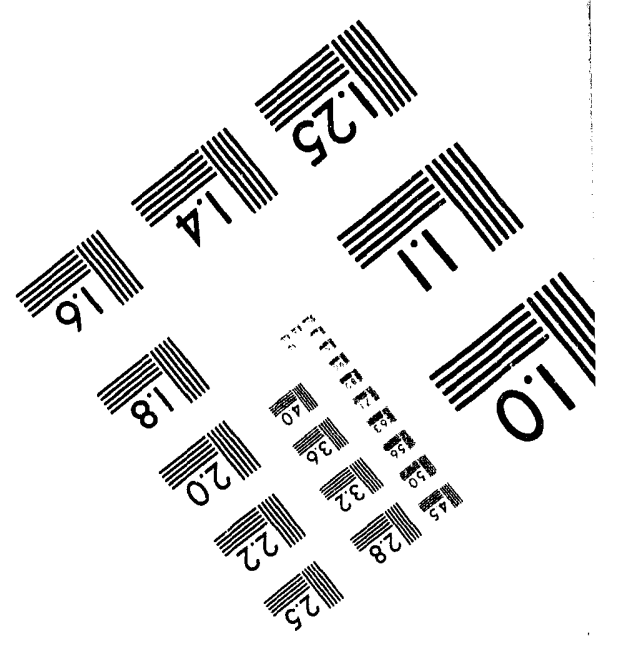



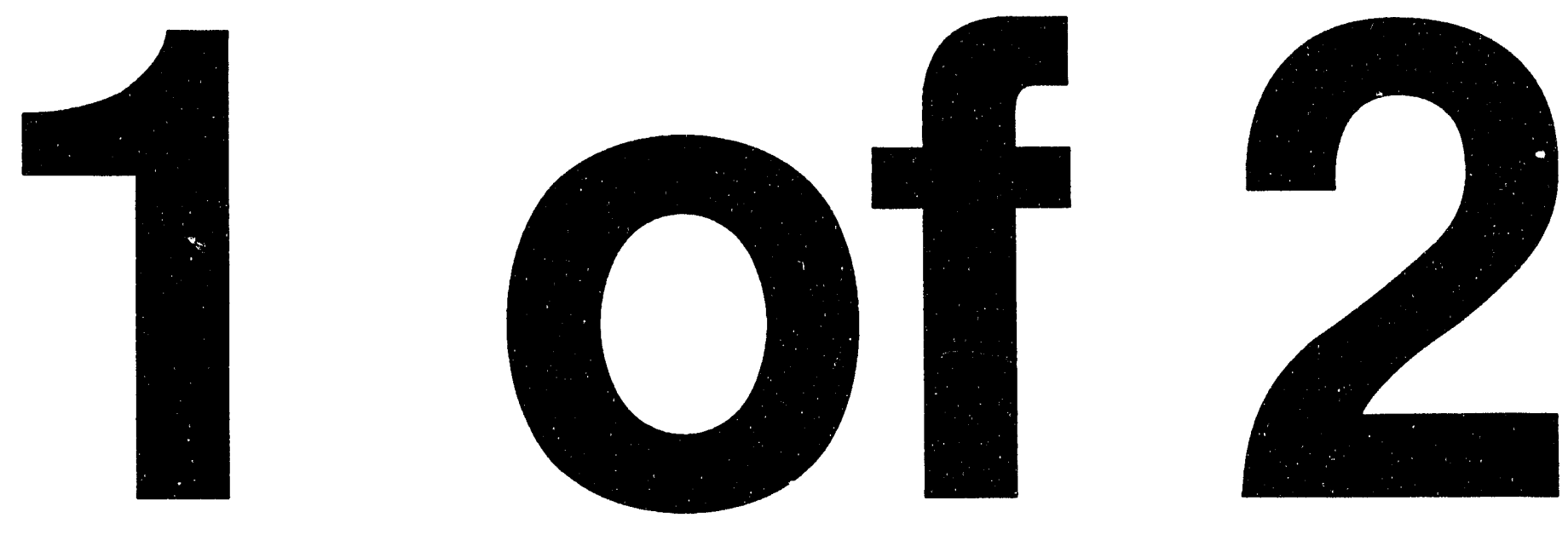


\section{Long-Term Surveillance Plan FOR THE GREEN RIVER, UTAH, DISPOSAL SITE}

August 1994

$$
\begin{gathered}
\text { RECEIVED } \\
\text { SEP } 121994 \\
\text { OSTI }
\end{gathered}
$$

\section{DISCLAIMER}

This report was prepared as an account of work sponsored by an agency of the United States Government. Neither the United States Government nor any agency thereof, nor any of their employees, makes any warranty, express or implied, or assumes any legal liability or responsibility for the accuracy, completeness, or usefulness of any information, apparatus, product, or process disclosed, or represents that its use would not infringe privately owned rights. Reference herein to any specific commercial product, process, or service by trade name, trademark, manufacturer, or otherwise does not necessarily constitute or imply its endorsement, recommendation, or favoring by the United States Government or any agency thereof. The views and opinions of authors expressed herein do not necessarily state or reflect those of the United States Government or any agency thereof. 


\section{INTENDED FOR PUBLIC RELEASE}

This report has been reproduced from the best available copy. Available in paper copy and microfiche.

Number of pages in this report: 121

DOE and DOE contractors can obtain copies of this report from:

Office of Scientific and Technical Information

P.O. Box 62

Oak Ridge, TN 37831

(615) 576-8401

This report is publicly available from:

National Technical Information Service

Department of Commerce

5285 Port Royal Road

Springfield, VA 22161

(703) 487-4650 


\section{LONG-TERM SURVEILLANCE PLAN \\ FOR THE \\ GREEN RIVER, UTAH, \\ DISPOSAL SITE}

August 1994

This Report Supersedes Report No. UMTRA-DOE/AL-350206.0000

Prepared for

U.S. Department of Energy

UMTRA Project Office

Albuquerque, New Mexico

Prepared by

Jacobs Engineering Group Inc.

Albuquerque, New Mexico 
This is a controlled document. The holder of the document will be notified of page/content changes and will be responsible for inserting all changes to keep the document current. 
TABLE OF CONTENTS

Section

Page

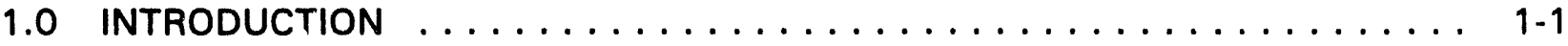

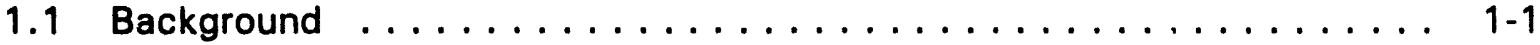

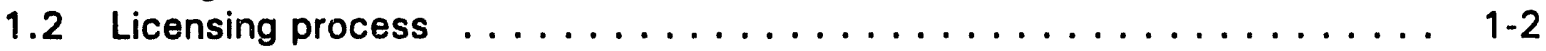

1.3 Acquisition ........................... 1-2

1.4 Long-term surveillance plan $\ldots \ldots \ldots \ldots \ldots \ldots \ldots \ldots \ldots \ldots \ldots$

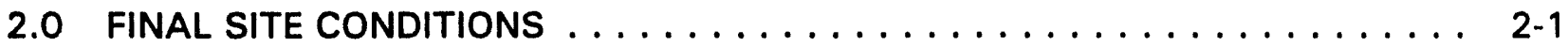

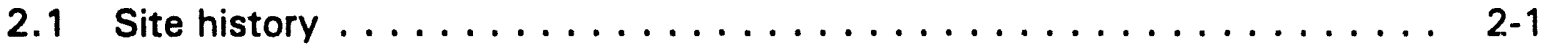

2.2 Final site conditions . . . . . . . . . . . . . . . . . 2-1

2.2.1 Description and location of the disposal site area . . . . . . . 2-1

2.2.2 Disposal site access and security ............... 2-1

2.2.3 Disposal cell design ................... 2-3

3.0 SITE DRAWINGS AND PHOTOGRAPHS $\ldots \ldots \ldots \ldots \ldots \ldots \ldots \ldots \ldots \ldots$

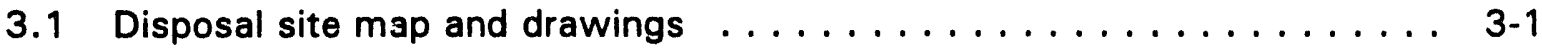

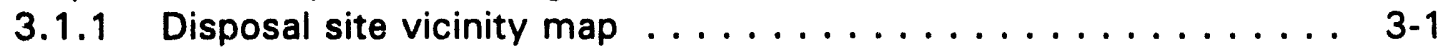

3.1 .2 Disposal site map . . . . . . . . . . . . . . . 3-1

3.1.3 Disposal site as-built drawings . . . . . . . . . . . . . 3-2

3.2 Site baseline photographs ..................... 3-2

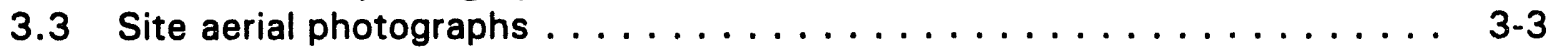

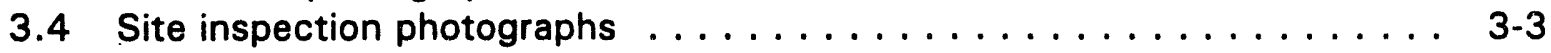

4.0 PERMANENT SITE SURVEILLANCE FEATURES $\ldots \ldots \ldots \ldots \ldots \ldots \ldots$

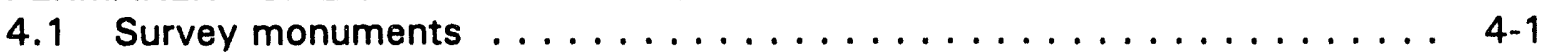

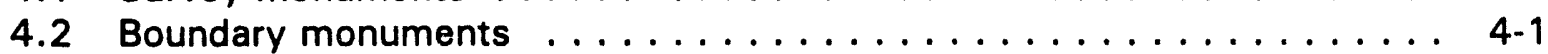

4.3 Site markers . . . . . . . . . . . . . . . . . . . . . . . 4-1

4.4 Entrance and perimeter signs $\ldots \ldots \ldots \ldots \ldots \ldots \ldots \ldots \ldots \ldots \ldots$

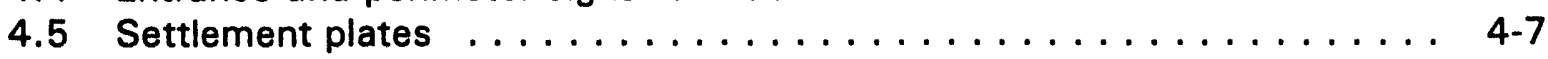

4.6 Additional site surveillance features . . . . . . . . . . . . . 4-7

4.7 Reference posts ........................ 4-7

5.0 GROUND WATER MONITORING $\ldots \ldots \ldots \ldots \ldots \ldots \ldots \ldots \ldots \ldots \ldots$

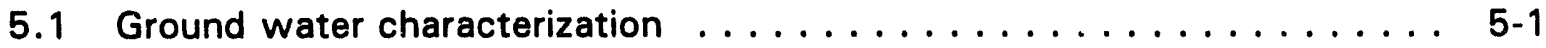

5.1 .1 Hydrostratigraphy .................... 5-1

5.1 .2 Background ground water quality .............. 5-2

5.1.3 Monitored constituents and concentration limits ......... 5-4

5.2 Ground water monitoring network . . . . . . . . . . . . . . 5-6

5.2 .1 Monitoring network .................. 5-8

5.2.2 Monitor well installation and development . . . . . . . . . . 5-10

5.3 Ground water monitoring program ................. $5-10$

5.3.1 Sampling frequency ................... 5-11

5.3.2 Screening monitoring and exceedance validation ........ 5-13

5.3.3 Evaluative monitoring .................. 5-13 
TARLE OF CONTENTS (Continued)

Section

Page

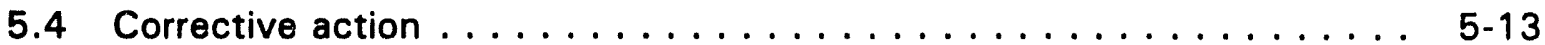

5.5 Data validation and quality assurance $\ldots \ldots \ldots \ldots \ldots \ldots \ldots \ldots$ 5-14

5.6 Reporting ........................... 5-15

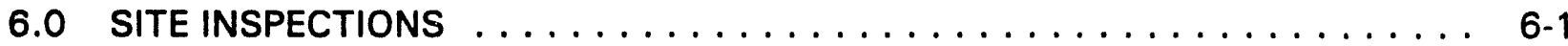

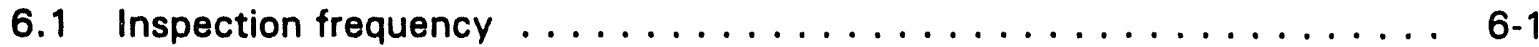

6.2 Inspection team ........................ $6-1$

6.3 Preparation for inspection . . . . . . . . . . . . . . . . 6-1

6.4 Site inspection and inspection checklist $\ldots \ldots \ldots \ldots \ldots \ldots \ldots \ldots$ 6.2

6.4.1 Modifying processes .................... 6-4

6.4 .2 Vegetation ........................ 6-4

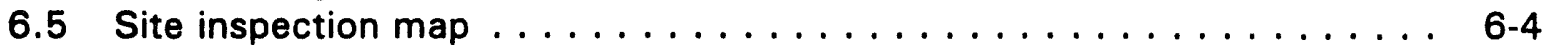

6.6 Reporting requirements .................... 6-5

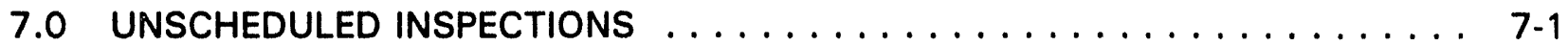

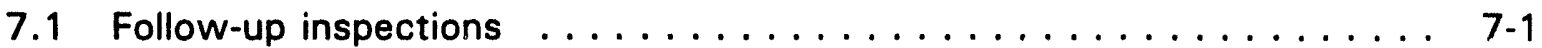

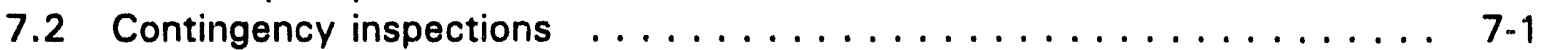

8.0 CUSTODIAL MAINTENANCE OR REPAIR $\ldots \ldots \ldots \ldots \ldots \ldots \ldots \ldots$

8.1 Planned maintenance ........................ 8 .1

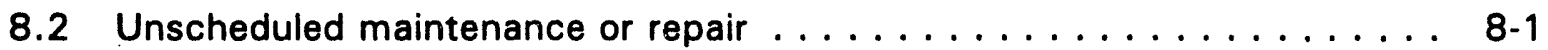

8.3 Certification and reporting requirements $\ldots \ldots \ldots \ldots \ldots \ldots$ 8-1

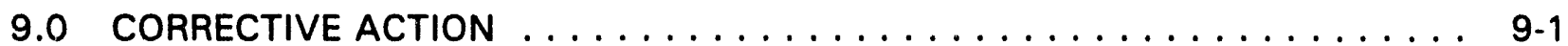

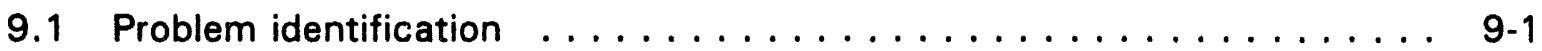

9.2 Certification and reporting requirements $\ldots \ldots \ldots \ldots \ldots \ldots$

10.0 RECORD KEEPING AND REPORTING REQUIREMENTS $\ldots \ldots \ldots \ldots \ldots \ldots$

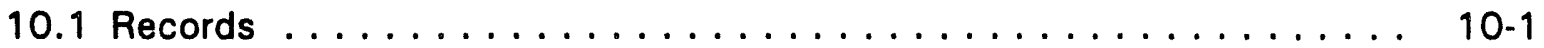

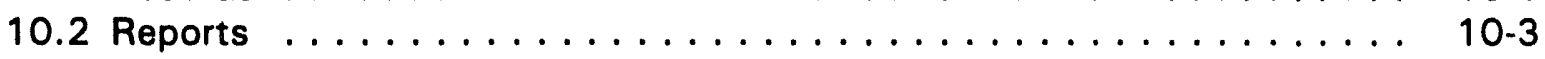

11.0 EMERGENCY NOTIFICATION AND REPORTING . . . . . . . . . . . 11-1

11.1 Agency agreements ....................... 11-1

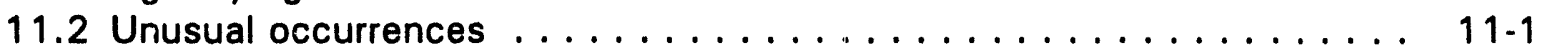

11.3 Earthquakes . . . . . . . . . . . . . . . . . . . . $11-1$

11.4 Meteorological events . . . . . . . . . . . . . . . 11-2

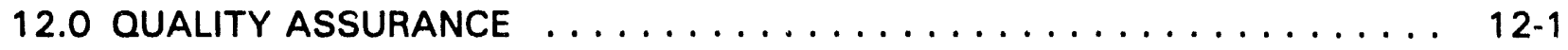

13.0 PERSONNEL HEALTH AND SAFETY $\ldots \ldots \ldots \ldots \ldots \ldots \ldots \ldots \ldots$ 3-1

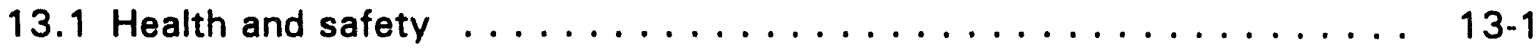

13.1.1 Unusual hazards and specific safety concerns . . . . . . . 13-1

13.1.2 Emergency medical and law enforcement . . . . . . . . 13-1 
TABLE OF CONTENTS (Concluded)

Section

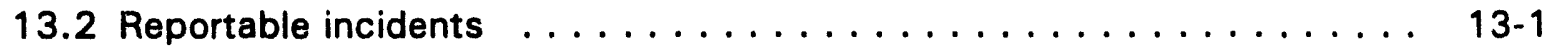

14.0 REFERENCES $\ldots \ldots \ldots \ldots \ldots \ldots \ldots \ldots \ldots \ldots \ldots \ldots \ldots \ldots \ldots \ldots \ldots$

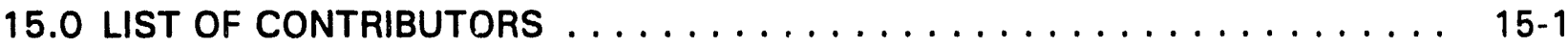

ATTACHMENT 1 NRC CONCURRENCE AND LICENSING DOCUMENTATION

ATTACHMENT 2 SITE OWNERSHIP/CUSTODY DOCUMENTATION

ATTACHMENT 3 GREEN RIVER PERMANENT SITE FILE INDEX

ATTACHMENT 4 SITE INSPECTION PHOTO LOG

ATTACHMENT 5 INITIAL SITE INSPECTION CHECKLIST

ATTACHMENT 6 AGENCY NOTIFICATION AGREEMENTS 


\section{LIST OF FIGURES}

Figure

Page

2.1 Green River site location map, Green River, Utah, site . . . . . . . . . . . . . 2-2

2.2 Plan view of the Green River disposal cell . . . . . . . . . . . . . . . . 2-4

2.3 Diagrammatic cross section of disposal cell and foundation, Green River, Utah, disposal site . . . . . . . . . . . . . . . . . . . . 2-6

2.4 Disposal cell cover system, Green River, Utah, disposal site . . . . . . . . . . 2-7

4.1 Survey monument, Green River, Utah, disposal site . . . . . . . . . . . . 4-2

4.2 Boundary monument, Green River, Utah, disposal site . . . . . . . . . . . . . 4-3

4.3 Entrance site marker (SMK 1 ) at the Green River, Utah, disposal site . . . . . . 4-4

4.4 Site marker (SMK 2) at crest of disposal cell, Green River, Utah, disposal site . . . . . . . . . . . . . . . . . . . . 4 4-5

4.5 Site marker incised message - Green River, Utah, disposal site . . . . . . . . . 4-6

4.6 Perimeter sign and message - Green River, Utah, disposal site . . . . . . . . . 4-8

4.7 Entrance sign and message-Green River, Utah, disposal site . . . . . . . . . 4. 4-9

5.1 Potentiometric surface contour map, Green River disposal site . . . . . . . . 5-3

5.2 Disposal site monitor well system, Green River, Utah . . . . . . . . . . . . . 5-9

5.3 UMTRA Project groundwater monitoring program $\ldots \ldots \ldots \ldots \ldots \ldots$. . . .

9.1 Corrective action-UMTRA Project long-term surveillance program $\ldots \ldots \ldots$. . $9-2$

9.2 Key elements in the corrective action process $\ldots \ldots \ldots \ldots \ldots \ldots \ldots$

\section{LIST OF PLATES}

Plate 1 Disposal site vicinity map

Plate 2 Disposal site map

\section{LIST OF TABLES}

Table

Page

2.1 Green River disposal site access key holders $\ldots \ldots \ldots \ldots \ldots \ldots \ldots \ldots$

3.1 Aerial photography specifications for the Green River disposal site $\ldots \ldots$. . . 3-4

5.1 Listed hazardous constituents for ground water for the UMTRA Project disposal sites (40 CFR $\$ 192.02$ (1994)) . . . . . . . . . 5-5

5.2 Hazardous constituents and protection limits for the Green River disposal site . . . . . . . . . . . . . . . . . . . . . . . . . . . 5 5-7

5.3 List of constituents recommended for long-term monitoring . . . . . . . . . 5-8 


\section{LIST OF ACRONYMS AND ABBREVIATIONS}

\section{Acronym}

ac

${ }^{\circ} \mathrm{C}$

$\mathrm{cm}$

$D^{50}$

DOE

DQO

EA

EPA

OF

fi

GJPO

ha

in

$\mathrm{km}$

LTSP

$\mathrm{m}$

$\mathrm{mm}$

$m^{3}$

$\mathrm{mi}$

$\mathrm{MCL}$

$\mathrm{mg} / \mathrm{L}$

MSL

NRC

NWS

POC

QA

QC

RAP

RRM

SOP

TDS

TEGD

UMTRA

UMTRCA

UPDCC

USGS

yd

$y d^{3}$
Definition

acre

degrees Celsius

centimeter

median diameter

U.S. Department of Energy

data quality objective

environmental assessment

U.S. Environmental Protection Agency

degrees Fahrenheit

foot

Grand Junction Projects Office

hectare

inch

kilometer

long-term surveillance plan

meter

millimeter

cubic meter

mile

maximum concentration limit

milligrams per liter

mean sea level

U.S. Nuclear Regulatory Commission

National Weather Service

point of compliance

quality assurance

quality control

remedial action plan

residual radioactive materials

standard operating procedure

total dissolved solids

Technical Enforcement Guidance Document

Uianium Mill Tailings Remedial Action

Uranium Mill Tailings Radiation Control Act

UMTRA Project Document Control Center

U.S. Geological Survey

yard

cubic yard 


\subsection{INTRODUCTION}

The long-term surveillance plan (LTSP) for the Green River, Utah, Uranium Mill Tailings Remedial Action (UMTRA) Project disposal site describes the surveillance activities for the Green River disposal cell. The U.S. Department of Energy (DOE) will carry out these activities to ensure that the disposal cell continues to function as designed. This final LTSP was prepared as a requirement for acceptance under the U.S. Nuclear Regulatory Commission (NRC) general license for custody and long-term care of residual radioactive materials (RRM). This LTSP documents whether the land and interests are owned by the United States or an Indian tribe and details how the long-term care of the disposal site will be carried out. The Green River, Utah, LTSP is based on the DOE's Guidance for Implementing the UMTRA Project Long-term Surveillance Program (DOE, 1992a).

\section{$1.1 \quad$ BACKGROUND}

Title I of the Uranium Mill Tailings Radiation Control Act (UMTRCA) of 1978 (42 USC $\$ 7901$ et seq.) authorized the DOE to perform remedial action at 24 inactive uranium mill tailings sites to reduce the potential effect on public health from unstabilized RRM in and around the uranium mill tailings. The Green River, Utah, uranium processing site in Grand County was one of the 24 sitis identified for remediation in the UMTRCA. Effective May 15, 1980, the DOE and the state of Utah entered into a cooperative agreement under the UMTRCA, establishing the terms and conditions of the remedial action (DOE Cooperative Agreement No. DE-FC04-81AL16309) (DOE, 1991; 1988). Remedial action began in November 1988 and was completed in September 1989. The RRM (tailings) and other contaminated materials at the Green River designated processing site were stabilized on the site in a permanent disposal facility about 600 feet ( $\mathrm{ft}$ ) (180 meters [m]) southeast of the uranium processing site. The NRC has concurred with the DOE's determination that remedial action at the Green River site is complete. Attachment 1 contains NRC concurrence and licensing documentation.

The excavated quantities of tailings and contaminated materials consist of approximately 204,249 cubic yards $\left(\mathrm{yd}^{3}\right)\left(156,169\right.$ cubic meters $\left.\left[\mathrm{m}^{3}\right]\right)$ of tailings, $138,217 \mathrm{yd}^{3}\left(105,681 \mathrm{~m}^{3}\right)$ of other contaminated material (including windblown-contaminated soil), and $39,295 \mathrm{yd}^{3}\left(30,045 \mathrm{~m}^{3}\right)$ of vicinity property contaminated material. The additional contaminated material is mostly windblown-contaminated soil with a smaller amount of vicinity property material found after site and vicinity property remedial action had begun.

The tailings and other contaminated materials are consolidated in a below-grade area; the resulting disposal cell is contoured to have 20-percent 15 horizontal to 1 vertical) sideslopes. To ensure compliance with U.S. Environmental Protection Agency (EPA) standards (40 CFR Part 192 (1994)), the tailings and contaminated materials are covered with $3 \mathrm{ft}(0.9 \mathrm{~m})$ of compacted earth (radon/infiltration barrier) to inhibit the emanation of radon and the infiltration of water. The topslope and sideslopes of the disposal cell are covered with a $0.5-\mathrm{ft}(0.2-\mathrm{m})$-thick layer of sand and gravel and a $1-\mathrm{ft}(0.3-\mathrm{m})$-thick layer of 
rock to protect the radon/infiltration barrier from erosion. These layers also protect against penetration by animals and prevent human intrusion.

The stabilized disposal cell covers approximately 5 acres (ac) ( 2 hectares [ha]) and is approximately 530 by $450 \mathrm{ft}(160$ by $140 \mathrm{~m})$ along the sides. After remedial action, the area of the existing tailings pile was backfilled, graded to promote surface drainage, and revegetated. All other areas disturbed at the site by remedial action have been backfilled and graded to promote surface drainage.

\subsection{LICENSING PROCESS}

The NRC has developed regulations (10 CFR $\$ 40.27$ (1994)) (effective November 29, 1990 [55 FR 45591 (1990)]) issuing a general license for the long-term care of DOE UMTRA Project (Title I) disposal sites, including the Green River disposal site. The license is available only to the DOE (or any successor federal agency designated by the President of the United States) and has no termination date. The purpose of this general license is to ensure that the UMTRA Project disposal sites will be cared for in a manner that protects public health and safety and the environment. The license takes effect at a site after the NRC concurs that remedial action is complete at that site (i.e., accepts the site-specific completion report and certification summary) and formally accepts a site-specific LTSP that meets the requirements of 10 CFR $\$ 40.27$ (1994). The site-specific completion report documents the site as-built conditions. The DOE prepares a certification summary memorandum certifying satisfaction of approved remedial action plan (RAP) provisions and compliance with EPA standards. The DOE compiles the final completion report, final audit report, and certification summary into the certification report and submits it to the NRC for concurrence (DOE, 1993). Because the Green River processing site uranium mill tailings were stabilized on the site, the site will be licensed in two steps: surface remediation and ground water restoration.

The DOE will conduct long-term surveillance activities at the Green River disposal site unless the President of the United States designates another federal agency to perform these activities. The DOE UMTRA Project Office will conduct interim surveillance activities at the disposal site until the NRC issues Phase $\mathrm{I}$ of the license. At that time, the long-term surveillance and maintenance activities will be transferred to the DOE Grand Junction Projects Office (GJPO).

\subsection{ACQUISITION}

The state of Utah acquired 103.5 ac (42 ha) of land from Umetco Minerals Corporation. The final disposal site is located within the boundaries of the state-owned land. The fee simple title obtained from Umetco conveys all reservations of oil, gas, and mineral rights owned or leased. The area encompassed by the final site boundaries is $21.5 \mathrm{ac}(8.7 \mathrm{ha})$.

Attachment 2 contains land ownership documentation. It includes two legal land descriptions: the final site boundaries, which define the area whose title 
will be transferred to the United States of America, and the boundaries of the state-owned land. Both boundarie: are labeled on the disposal site map in Plate 1.

Once the disposal site title transfers from the state of Utah to the United States of America, the documentation of this land transaction will be included in the Green River permanent site file and in Attachment 2. The DOE, or another federal agency that the President of the United States may designate, will have perpetual custody of the Green River disposal site and the permanent right of entry to undertake any monitoring, maintenance, and emergency measures necessary to protect nublic health and safety and the environment.

The NRC and the state of Utah concurred with the DOE's RAP (DOE, 1991 ; under the requirements of EPA-proposed standards in 52 FR 36000 (1987) (Aitactiment 1). The remedial actions were described and evaluated in an environmental assessment (EA) (DOE, 1988) prepared by the DOE. Ground water restoration activities at the processing site will be implemented at a later date.

The NRC has concurred with the completion of surface remedial action (Attachment 1).

\subsection{LONG-TERM SURVEILLANCE PLAN}

This document describes the long-term surveillance program to be implemented at the Green River disposal site to ensure that the disposal cell continues to perform as designed. The plan is based on the DOE's Guidance for Implementing the UMTRA Project Long-term Surveillance Program (DOE, 1992a).

This LTSP meets the requirements of 10 CFR $\$ 40.27$ (1994) by addressing the following:

- Site description and ownership.

- Description of final site conditions.

- Site inspection procedures and personnel.

- Custodial maintenance and corrective action programs.

- Record keeping and reporting.

- Quality assurance monitoring activities.

- Emergency response. 


\subsection{FINAL SITE CONDITIONS}

\subsection{SITE HISTORY}

The uranium processing mill at the Green River site was built in 1957 by Union Carbide Corporation. The mill operated from March 1958 through January 1961. During that time, the uranium mill processed 183,000 tons $(166,018$ tonnes) of ore averaging 0.29 percent uranium oxide, producing an ore concentrate that was shipped by railroad to the company's processing plant in Rifle, Colorado (DOE, 1988).

\section{$2.2 \quad$ FINAL SITE CONDITIONS}

\subsubsection{Description and location of the disposal site area}

The Green River disposal site is located in Grand County, Utah, 1 mile (mi) (1.6 kilometers [km]) southeast of the city of Green River and $0.5 \mathrm{mi}(0.8 \mathrm{~km}$ ) south of U.S. Highway $6 \& 50$ (U.S. 6\&50) (Figure 2.1). The disposal site is in the Gunnison Valley; this valley is bordered on the north by the Book Cliffs and on the south by the San Rafael Valley. The area contains cliffs, mesas, and the Gray Canyon of the Green River.

The area's climate is arid, with an average annual precipitation of 6.2 inches (160 millimeters [mm]) for the period 1951 through 1980. Average temperatures at the site vary from 23 degrees Fahrenheit $\left({ }^{\circ} \mathrm{F}\right)(-5$ degrees Celsius $\left.\left[{ }^{\circ} \mathrm{C}\right]\right)$ in January to $78^{\circ} \mathrm{F}\left(26^{\circ} \mathrm{C}\right)$ in July. Vegetation in the immediate site area consists of species common to the arid desert environment (e.g., greasewood, saltbush, rabbitbrush, Indian ricegrass, and galleta grass). The elevation above mean sea level (MSL) at the site varies from $4064 \mathrm{ft}(1239 \mathrm{~m})$ along the northern boundary to $4144 \mathrm{ft}(1263 \mathrm{~m})$ along the southern boundary.

A portion of the disposal site is in the 100-year and 500-year floodplains of Brown's Wash, an intermittent tributary of the Green River that flows southward and discharges into the Colorado River 60 air mi $(97 \mathrm{~km})$ south of the city of Green River. The disposal site is bordered by a mainline track of the Denver and Rio Grande Western Railroad on the north and Interstate 70 (1-70) on the south. The mill buildings and a water tower were decontaminated and left intact at the uranium processing site. No historical or cuitural resources or any threatened and endangered species were affected by the remedial actions at the disposal site.

\subsubsection{Disposal site access and security}

To reach the Green River disposal site from U.S. 6\&50, turn south at 1170 East Street and proceed $0.25 \mathrm{mi}(0.4 \mathrm{~km})$ to Elgin Avenue. Turn west on Elgin Avenue and proceed $0.5 \mathrm{mi}(0.8 \mathrm{~km})$ to 800 East Street. Turn south at 800 East Street and proceed $0.25 \mathrm{mi}(0.4 \mathrm{~km})$ to 900 South Street. Turn east at 900 South Street and proceed $0.25 \mathrm{mi}(0.4 \mathrm{~km})$ to the site access road. 


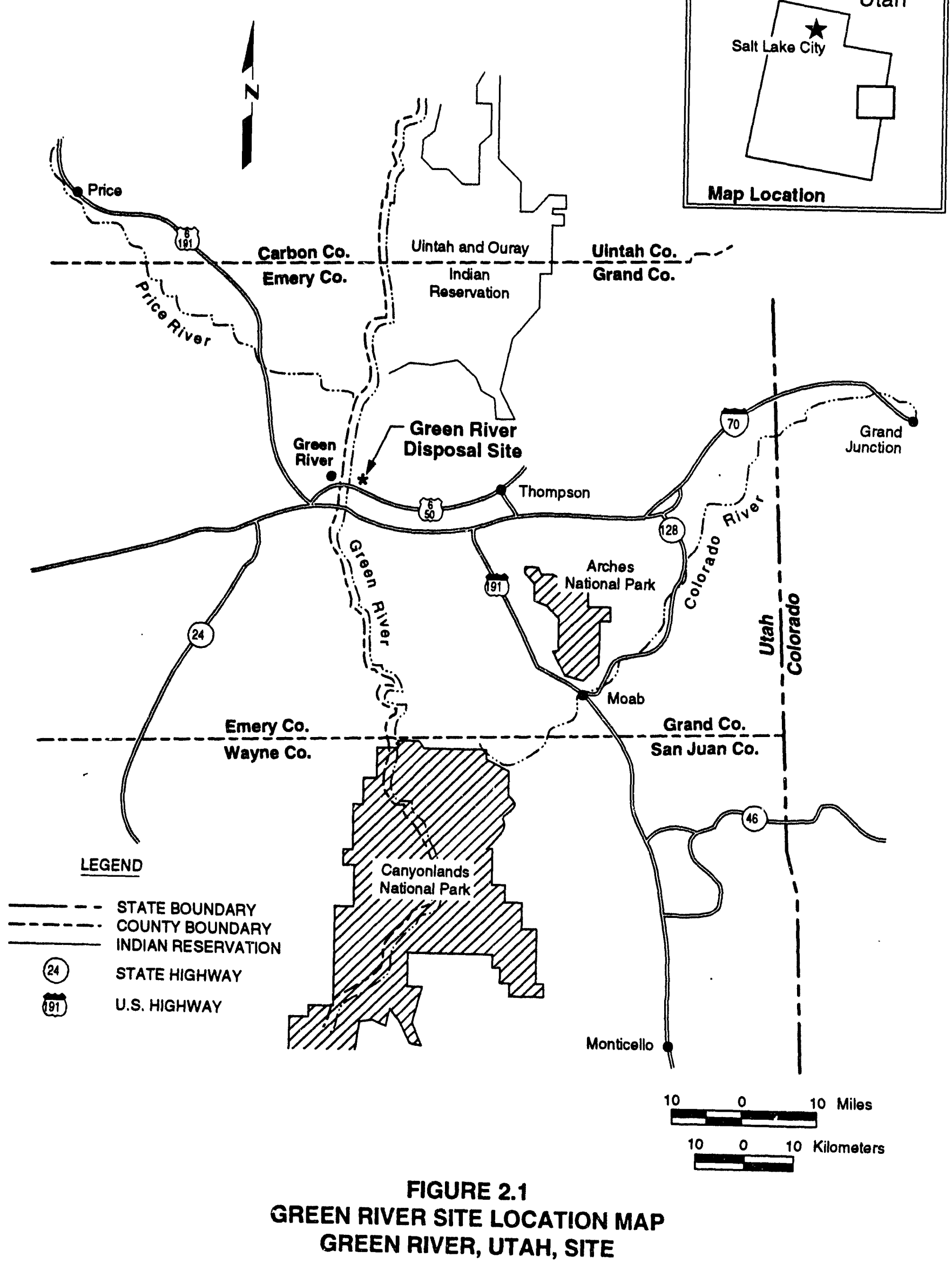


Rights of way and access to the site were acquired through a real estate acquisition in accordance with a quitclaim deed. Attachment 2 contains the recorded date of this acquisition and the locations of subject files.

Disposal site keys are maintained by the DOE UMTRA Project Manager; the TAC UMTRA Project Manager; and the GJPO Supervisory, General Engineer (Table 2.1).

Table 2.1 Green River disposal site access key holders

\begin{tabular}{|c|c|c|}
\hline $\begin{array}{l}\text { Title and } \\
\text { current contact }\end{array}$ & Telephone & Address \\
\hline DOE UMTRA Project Manager & $(505) 845-4022$ & $\begin{array}{l}\text { U.S. Department of Energy } \\
\text { UMTRA Project Office } \\
2155 \text { Louisiana NE } \\
\text { Suite } 4000 \\
\text { Albuquerque, NM } 87111\end{array}$ \\
\hline TAC UMTRA Project Manager & $(505) 888-1300$ & $\begin{array}{l}\text { Jacobs Engineering Group } \\
2155 \text { Louisiana NE } \\
\text { Suite } 10,000 \\
\text { Albuquerque, NM } 87111\end{array}$ \\
\hline $\begin{array}{l}\text { Supervisory, General } \\
\text { Engineer, GJPO }\end{array}$ & (303) 248-6006 & $\begin{array}{l}2597 \text { B } 3 / 4 \text { Road } \\
\text { Grand Junction, CO } 81503\end{array}$ \\
\hline
\end{tabular}

The state of Utah maintains a fence surrounding an area that includes the disposal site. No other permanent security measures are in place.

\subsubsection{Disposal cell design}

The stabilized disposal cell was constructed primarily below the existing ground surface; it contains $339,377 \mathrm{yd}^{3}\left(259,488 \mathrm{~m}^{3}\right)$ of compacted tailings. The dimensions of the disposal cell are approximately $530 \mathrm{ft}(160 \mathrm{~m})$ by $450 \mathrm{ft}$ $(140 \mathrm{~m})$, including the 20-ft $(6-\mathrm{m})$-wide toe apron (Figure 2.2).

Contaminated materials were placed on a 6-ft $(2-\mathrm{m})$-thick layer of compacted clean fill, then covered with a silty clay material (radon/infiltration barrier). The disposal cell was capped with large-diameter rock that prevents wind and water erosion of the radon/infiltration barrier and underlying contaminated material. Slopes of the disposal cell are 5 horizontal to 1 vertical (20 percent), and the maximum elevation of the cell is $4181 \mathrm{ft}(1274 \mathrm{~m})$ above MSL.

The location of the disposal cell was selected for protection against erosion from Brown's Wash and undercutting of the disposal cell by gully formation. 


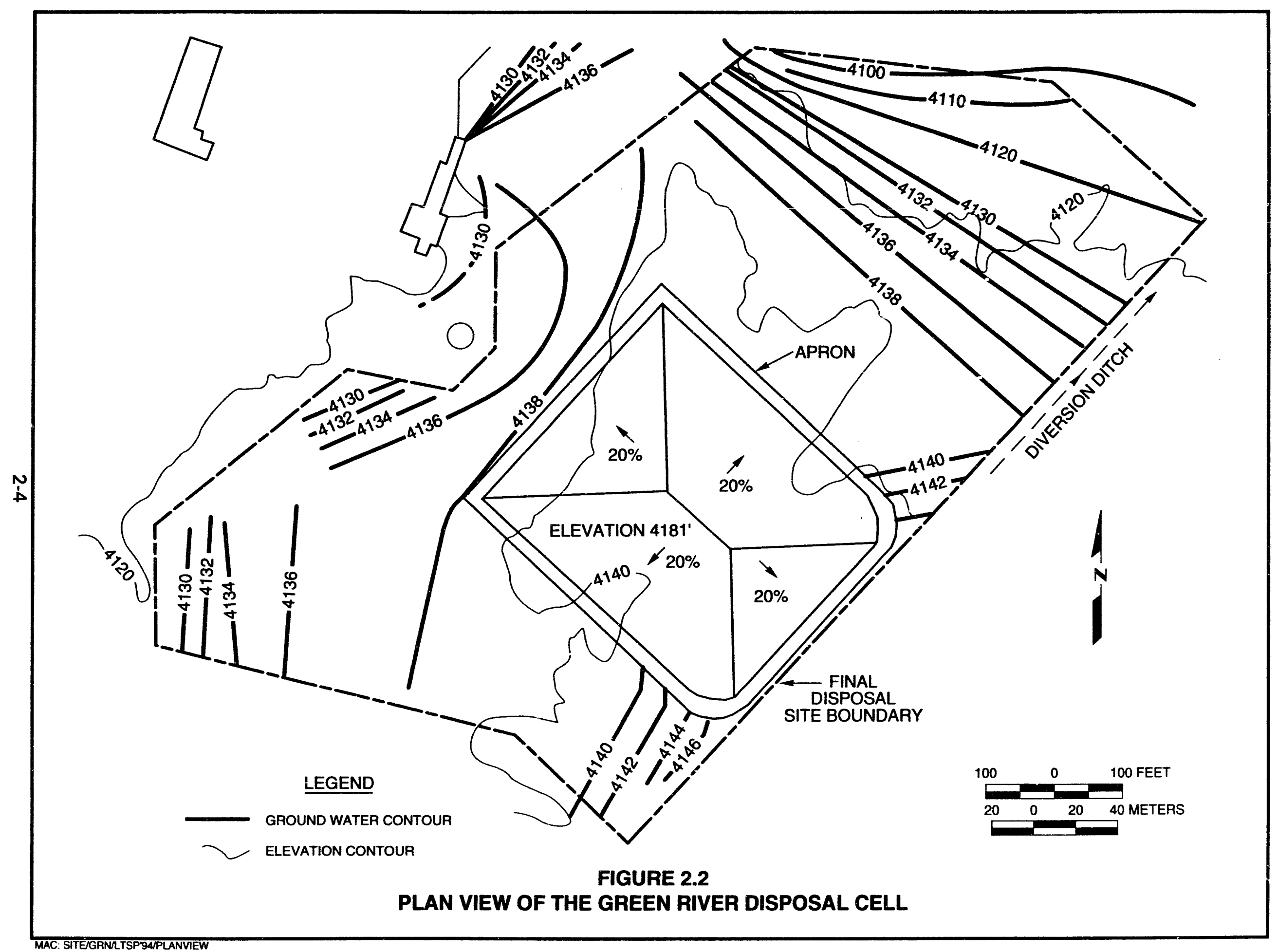


The excavation for the below-grade portion of the disposal cell extended into bedrock of the Dakota and Cedar Mountain Formations (maximum depth of $43 \mathrm{ft}$ [13 m]). Contaminated material was placed and compacted on top of a 6-ft (2-m)-thick layer of select fill at the bottom of the excavation (Figure 2.3).

The infiltration/radon barrier was covered by an erosion protection layer designed to protect the disposal cell from runoff, flooding, and the encroachment of gullies. The uppermost portion of the erosion protection layer is a layer of Type A riprap 12 inches $(300 \mathrm{~mm}$ ) thick (Figures 2.3 and 2.4). The median diameter $\left(D_{50}\right.$ rock size for Type $A$ riprap is 2 inches $(50 \mathrm{~mm})$. A 6-inch $(150-\mathrm{mm})$-thick bedding layer was placed between the riprap and the infiltration/radon barrier to prevent migration of the infiltration/radon barrier into the riprap. A buried apron consisting of Type B riprap a minimum of 36 inches $(910 \mathrm{~mm})$ thick was placed below grade around the toe of the cell. The $D_{50}$ rock size for Type B riprap is 18 inches $(460 \mathrm{~mm})$. A 12-inch $(300-\mathrm{mm})$-thick layer of Type A riprap and a 6-inch $(150-\mathrm{mm})$-thick layer of bedding material was constructed between the infiltration/radon barrier and Type $B$ riprap to prevent migration of the infiltration/radon barrier material into the Type B riprap (Figure 2.3). Riprap toe protection extends about $20 \mathrm{ft}(6 \mathrm{~m})$ on the surface from the disposal cell toe to reduce erosion of the ground surface adjacent to the disposal cell. Existing gulies near the disposal cell were regraded and filled to minimize erosion potential and the formation of new gullies.

The 36-in (910-mm)-thick infiltration/radon barrier was placed over the contaminated materials. This barrier was constructed of compacted silty clay and was designed to 1) protect ground water by minimizing infiltration, and 2) reduce radon flux from the disposal cell to less than 20 picocuries per square meter per second. Six percent bentonite by weight was mixed into the radon barrier material to ensure that the compacted infiltration/radon barrier has a saturated hydraulic conductivity of less than $2 \times 10^{-8}$ centimeters per second. Twenty-one inches $(530 \mathrm{~mm})$ of the infiltration/radon barrier are below the maximum projected frost depth. of 39 inches $(990 \mathrm{~mm})(D O E, 1991)$ at the toe of the sideslopes.

The specifications for placement of materials were prepared to minimize and control the use of water to meet maximum concentration limits $(\mathrm{MCL})$ or background levels in ground water at the disposal site monitor wells for the identified hazardous constituents (refer to Section 5.0). The 20-percent slopes, in conjunction with the filter bedding layer, will cause most excess surface water to run off the disposal cell, thus minimizing the potential for precipitation to infiltrate into contaminated material.

The surface conditions of the disposal cell will be monitored during yearly inspections to determine whether the disposal cell and erosion protection measures are performing as designed. Guidelines to be followed when inspecting the disposal cell and criteria for corrective actions or repairs are as follows: 


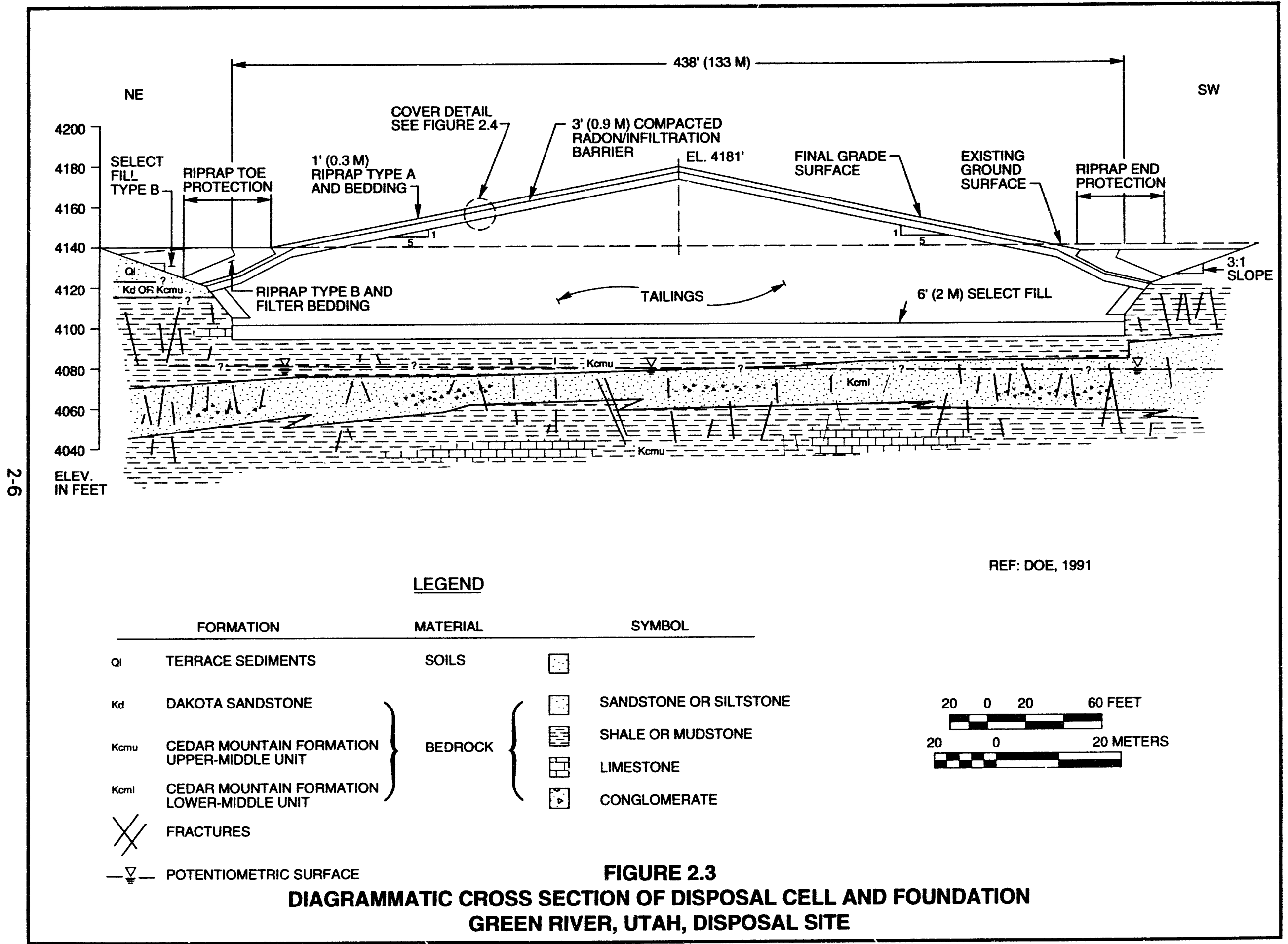




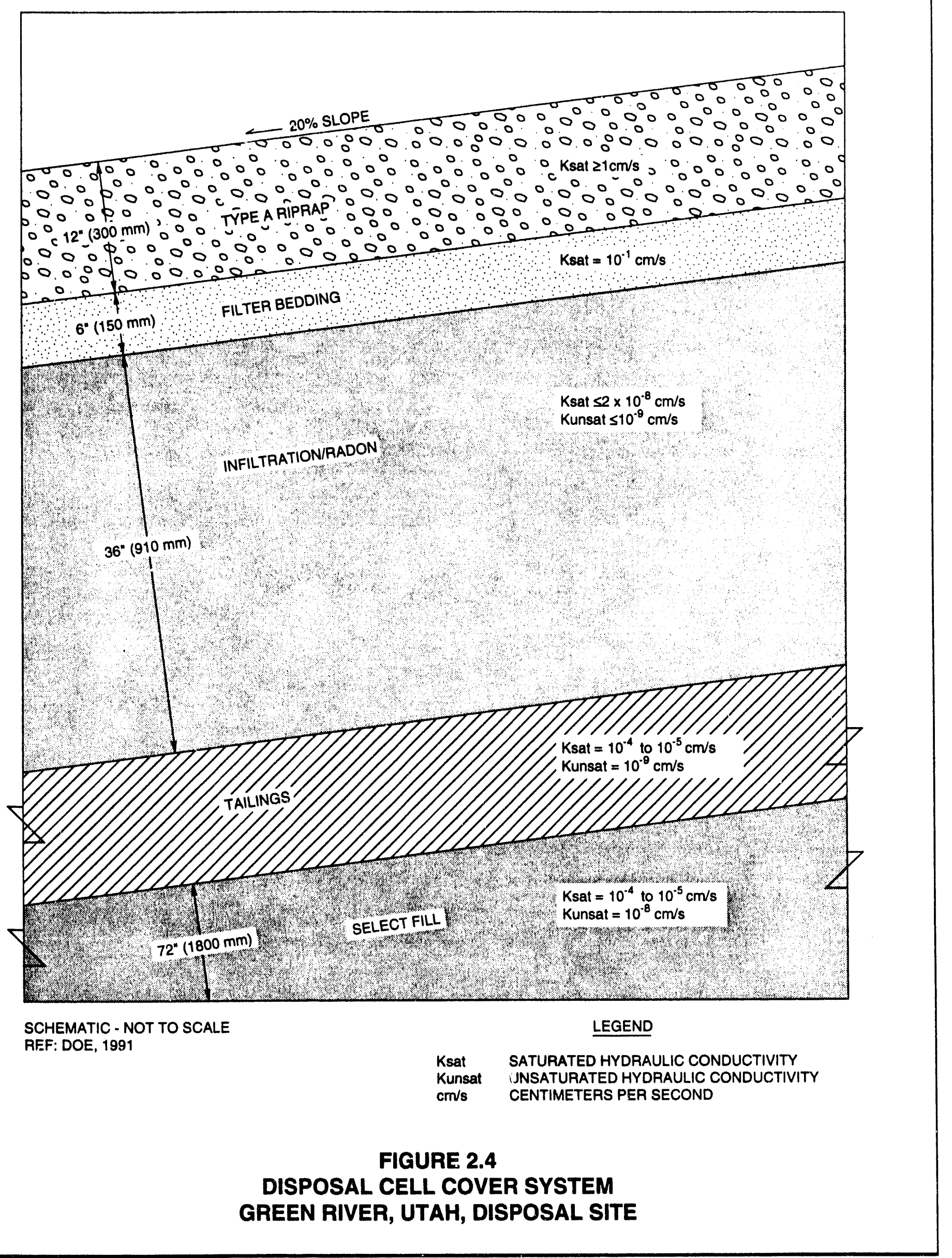


- Crest - Observations will be made in all directions of any features that are anomalous or unexpected and that may require a closer inspection. Inspectors will walk around the edge and along diagonal transects of the crest. Additional transects, at approximate 50-yard (yd) (46-m) interva!s, will be walked along the sideslopes. The inspectors will search for evidence of any differential settling, subsidence, or cracks. The rock cover will be examined for evidence of rapid deterioration. Individual rocks will be examined for excessive fracturing, oxidation, or other signs of deterioration. The inspectors will also note whether rock and other cover material has been removed or displaced.

- Gullies, rills, ditches, swales - The inspectors will walk along the entire length of any ditches or man-made swale in the immediate vicinity of the disposal site to determine whether the channels have been functioning, and can be expected to continue to function, as designed. The channels and sideslopes of ditches and swales will be examined for evidence of erosion or sedimentation, slides, or incipient erosion channels, debris, growing vegetation, or burrowing animals.

The designated disposal site and the area surrounding the site will be surveyed carefuily to determine whether deep or severe gullies and widespread rills are developing.

Measures for initiating corrective action or repair to engineering features at the Green River disposal site are as follows:

- Erosion of, or gully or rill formation in, underlying cover layers caused by missing or displaced riprap.

- Obvious deterioration of erosion protection rock (for example, fragmentation of large-diameter rock).

- Development of rills on the designated disposal site. The severity of the problem will be determined by the soil type (where rills are reported) and the size of the area affected.

- Development of gullies within the disposal site boundary or adjacent to site boundaries that could warrant concern, based on the inspectors' professional judgment.

- Undercutting of the soil around the disposal cell toe apron. 


\subsection{SITE DRAWINGS AND PHOTOGRAPHS}

At the completion of remedial action, disposal site as-built conditions were documented with as-built drawings, baseline photographs, and aerial photographs (MK-F, 1991). This information will be used to illustrate baseline conditions against which future conditions at the disposal site can be compared. Photographs taken during site inspections will provide continuing documentation of changing conditions at the disposal site.

\subsection{DISPOSAL SITE MAP AND DRAWINGS}

A site atlas has been prepared that includes a disposal site vicinity map and a disposal site map (Plates 1 and 2). This site atlas will be updated, as necessary, after each site inspection. All drawings, maps, and photographs will be archived in the UMTRA Project Document Control Center (UPDCC). These maps, drawings, and photographs may be further modified by the GJPO, as necessary, and the GJPO will be responsible for maintaining and archiving these maps, drawings, and photographs after the Green River permanent site file is transferred to the GJPO. An index of the Green River permanent site file is provided in Attachment 3.

\subsubsection{Disposal site vicinity map}

The disposal site vicinity map (Plate 1$)$ encompasses a $3.0-\mathrm{mi}(4.8-\mathrm{km})$ radius and includes the following information:

- The scale (1 inch equals $1000 \mathrm{ft}$ ).

- County boundaries.

- Disposal site boundary and state-owned legal boundary.

- Longitude and latitude and state plane coordinates; section, township, range.

- Primary drainage systems (Green River and Brown's Wash).

- Roads and buildings.

The disposal site vicinity map will be updated, as necessary, after each scheduled site inspection. The new map will include the revision number and the year of revision. All site maps and periodic site inspection maps will become part of the Green River permanent site file.

\subsubsection{Disposal site map}

The Green River disposal site map, including topographic features for the Green River disposal site, is included as Plate 2. The map identifies the following site features:

- The scale (1 inch equals $200 \mathrm{ft}$ ).

- The disposal site and an area of $0.25 \mathrm{mi}(0.40 \mathrm{~km})$ around the site perimeter. 
- The contour interval $(10 \mathrm{ft})$.

- The disposal site property boundary, fences, gates, and access roads.

- The outline of the toe base and crest of the disposal cell.

- Immediately adjacent geomorphic features that represent dynamic processes (Green River and Brown's Wash).

- Disposal site monitor wells.

- Other ground water monitor wells and access roads to them.

- Surveying control point.

- Permanent site surveillance features (e.g., monuments, markers, signs, and water tower).

- Site coordinate system.

Whon the disposal site map is updated, the revised map will include the year of revision and the revision number.

The Green River disposal site map will serve as the base map for the site inspection map. A new, separate inspection map will be prepared after each inspection. Each site inspection map will indicate the year of the inspection and the type of inspection. All site maps and site inspection maps will become part of the Green River permanent site file.

\subsubsection{Disposal site as-built drawings}

After remedial action was completed at the Green River disposal site, as-built drawings were made to illustrate the final disposal cell construction and final disposal site conditions. These drawings were used to prepare the disposal site map and will be stored in the Green River permanent site file. These drawings will be used to document changes in physical site conditions or changes to the disposal cell over time for developing corrective action plans, if required.

\subsection{SITE BASELINE PHOTOGRAPHS}

Two sets of baseline photographs will be placed in the Green River permanent site file. One set of photographs was taken during the remedial action to illustrate implementation of the final design and site construction methods. These photographs may provide useful construction details if corrective action or repairs become necessary. The other set of baseline photographs was taken at the end of construction to document as-built conditions. 


\section{SITE AERIAL PHOTOGRAPHS}

After construction activities were completed at the disposal site, aerial photographs were taken in the spring of 1990. These photographs were used to prepare the topographic map and provide a permanent record of as-built site conditions. These aerial photographs are useful as a baseline for comparing any changes in site conditions over time. The need for new aerial photographs will be assessed at regular 5-year intervals, unless unusual conditions require more frequent assessment. Unless site conditions require otherwise, the area photographed will include the disposal site and the area $0.25 \mathrm{mi}(0.40 \mathrm{~km})$ outside the site boundary. A summary of specifications for aerial photographs at the Green River disposal site is provided in Table 3.1. More detailed guidance is provided in the Guidance for Implementing the UMTRA Project Long-term Surveillance Program (DOE, 1992a).

\subsection{SITE INSPECTION PHOTOGRAPHS}

Photographs will be taken during site inspections to document conditions of the disposal cell and disposal site. The photographs will provide a continuous record for monitoring changing conditions over time. Tiiey can be compared with the baseline photographs to determine whether the integrity of the site has been affected. Those features for which photographic documentation would be routinely required will be determined in conjunction with the preparation of the site inspection checklist.

Each photograph will be recorded individually on the photo log form (Attachment 4). An appropriate description of the feature photographed, including the azimuth (if necessary), will be entered on the log form. Copies of the photographs and the photo logs will be included in annual inspection reports.

Whenever possible, a photograph should include a reference point such as a survey monument, boundary monument, site marker, or monitor well. For largescale features such as drainage ditches or disposal cell slopes, a north arrow and a scale will be included for reference.

For specific areas where the photograph is used to monitor changes over time, the distance from the feature and the azimuth will be recorded. All subsequent photographs will be taken from the same orientation to provide a more accurate picture of changing conditions. The magnetic declination of the compass should be corrected for true north. This information will also be provided on the site inspection checklist and photo log.

All site inspection photographs taken and all corresponding photo log forms will be maintained in the Green River permanent site file. 
Table 3.1 Aerial photography specifications for the Green River disposal site

Area to be photographed

Products to be delivered

Flight date

\section{Camera}

Film

Filter

Flight line coverage

Ground control
Final disposal site plus a minimum of $0.25 \mathrm{mi}(0.40 \mathrm{~km})$ beyond site boundaries unless site conditions require otherwise.

One set of vertical color, infrared stereo contact prints, 9 -inch $(230 \mathrm{~mm})$, scale 1 inch $=200 \mathrm{ft}(1 \mathrm{~mm}=$ $240 \mathrm{~m})$; double weight, glossy, not trimmed.

One index map, scale 1 inch $=200 \mathrm{ft}(1 \mathrm{~mm}=$ $240 \mathrm{~m})$; flight lines and frame numbers will be provided.

One set of two each of low and high oblique photographs (and negatives) in natural color, $8-x$ 10-inch (200- x 250-mm); or 9- x 9-inch (230- x 230$\mathrm{mm}$ ) contact prints.

To be determined upon the acceptance of this LTSP.

Precision, 9- $\times$ 9-inch (230- x 230-mm) format for vertical photos. A 35 -millimeter (single lens reflex) or larger format camera for oblique photos is acceptable.

Eastman-Kodak Aerochrome Infrared 2443, or its equivalent, for vertical photos.

Eastman-Kodak Ektacolor, or its equivalent, for oblique photos.

Wratten Nos. 12 or 15 for infrared photos. Skylight filter for color photos.

60 percent end overlap; 30 percent average side overlap.

Control stations will be second order, Class 1, for horizontal control and third order for vertical control (standard U.S. Geological Survey map accuracy specifications). 


\section{Features to be photographed}

The following disposal site features should be documented with photographs during every scheduled inspection at the Green River disposal site:

- Permanent site surveillance features.

- Disposal cell crest lines - both along the crest and at right angles to the crest.

- The disposal cell (top, sides, apron, and surrounding areas). Sufficient photographs should be taken to record the cell's condition. Panoramic sequences of photographs from selected vantage points may be used for this purpose.

- Off-site features that may affect the site in the future.

- Diversion channels or other drainage features.

- Vegetation.

- Areas of eolian sedimentation or erosion.

- Erosion north of the water tower.

- Rill erosion on the northern hillslope.

- Erosion near the southern perimeter signs.

Any new or potential problem areas identified during a site inspection will be well documented with photographs. Photographs will also be taken to provide a record of developing trends and to allow inspectors to make reasonable decisions concerning additional inspections, custodial maintenance or repairs, or corrective actions. 


\subsection{PERMANENT SITE SURVEILLANCE FEATURES}

Survey and boundary monuments, site markers, and entrance and pe-imeter signs will be the permanent surveillance and maintenance features at the Green River disposal site. Eight boundary monuments and three survey monuments define the 11 corners of the legal boundaries of the irregularly shaped permanent disposal site. Eighteen perimeter (warning) signs were placed at spaced intervals around the disposal site so that one or more signs will be visible in daylight to a person approaching from any direction. One of the perimeter signs and one site marker were placed at the official entrance to the disposal site at the southernmost corner. The other site marker was placed near the center of the crest of the disposal cell.

The construction and emplacement of the site surveillance features are described below and are in accorjance with the specifications delineated in the DOE's Guidance for Implementing the UMTRA Project Long-term Surveillance Program (DOE, 1992a).

\subsection{SURVEY MONUMENTS}

The three survey monuments (Figure 4.1), Berntsen RT-1 metal markers, were set into the top of a truncated cone of reinforced (precast) concrete that was set in concrete with the dimensions shown in Figure 4.1. The depth of the hole is a minimum of 18 inches $(460 \mathrm{~mm})$ below frost line, for a total depth of 57 inches $(1400 \mathrm{~mm})$, or to bedrock. Four reinforcing bars will allow a monument to be easily located with a metal detector should the monument become buried.

The survey monuments establish permanent horizontal control based on the project grid system and are referenced to the U.S. Geological Survey (USGS) triangulation station (station name: Boyd). The station is about $2 \mathrm{mi}(3 \mathrm{~km})$ east of Green River at the Green River Test Complex on White Sands Missile Range property.

\subsection{BOUNDARY MONUMENTS}

Berntsen federal aluminum survey monuments, Model A-1, were used for the eight boundary monuments (Figure 4.2). Ceramic magnets epoxied in the cap and base are vertically oriented so that the monuments can be found easily with a metal detector if they become covered. The monuments are $4 \mathrm{ft}(1.2 \mathrm{~m})$ long and extend at least 10 inches $(250 \mathrm{~mm})$ above ground surface (Figure 4.2).

\subsection{SITE MARKERS}

Two unpolished granite site markers constructed with the dimensions shown in Figures 4.3 and 4.4 identify the Green River disposal site, the general location of the stabilized disposal cell (tailings), the date of closure (September 15, 1989 ), the dry tonnage of tailings $(501,000)$, and the curies of radioactivity ( 30 curies of radium-226) (Figure 4.5). 


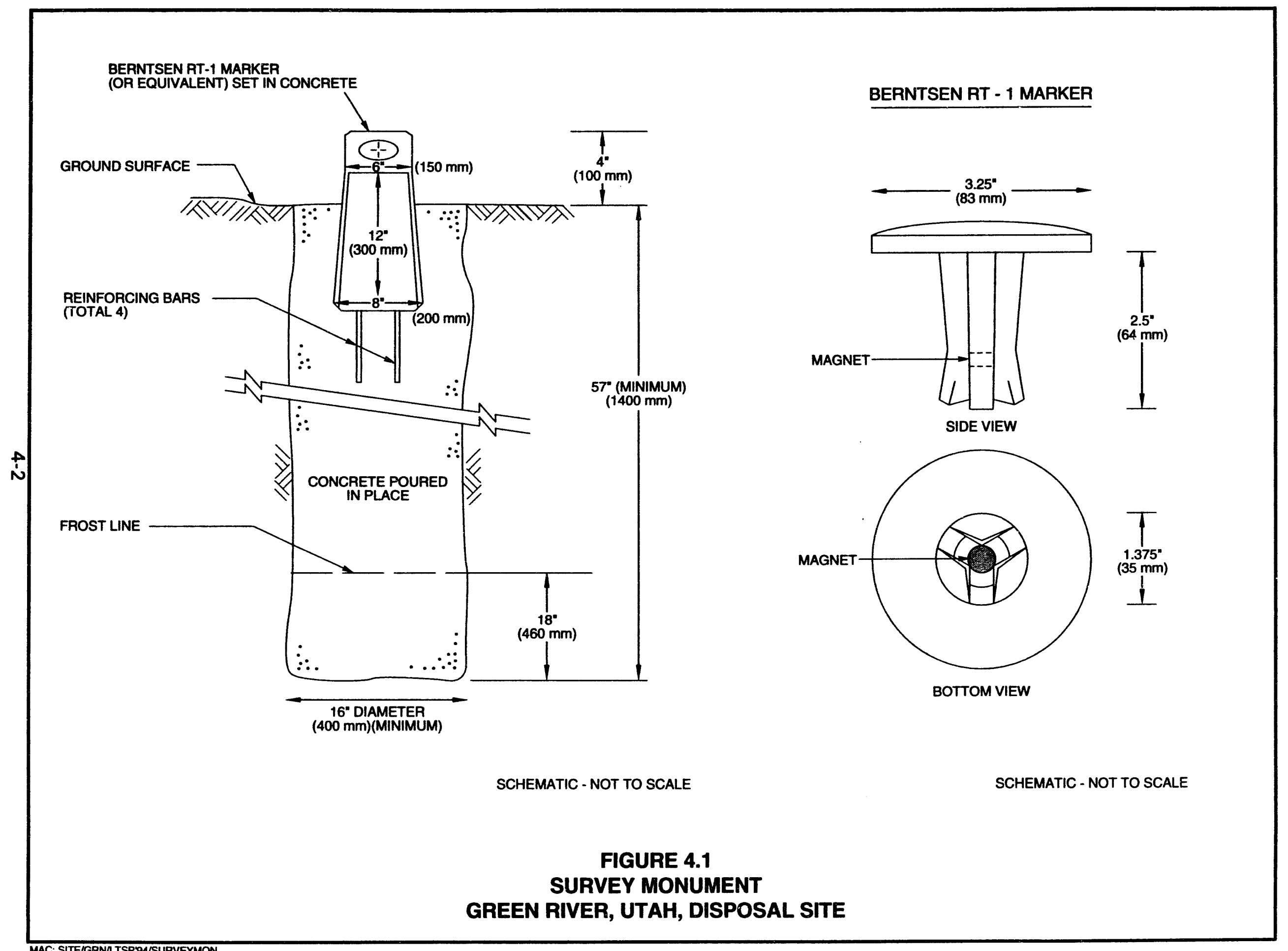

MAC: SITE/GRNRTSPYQ/SURVEYMON 


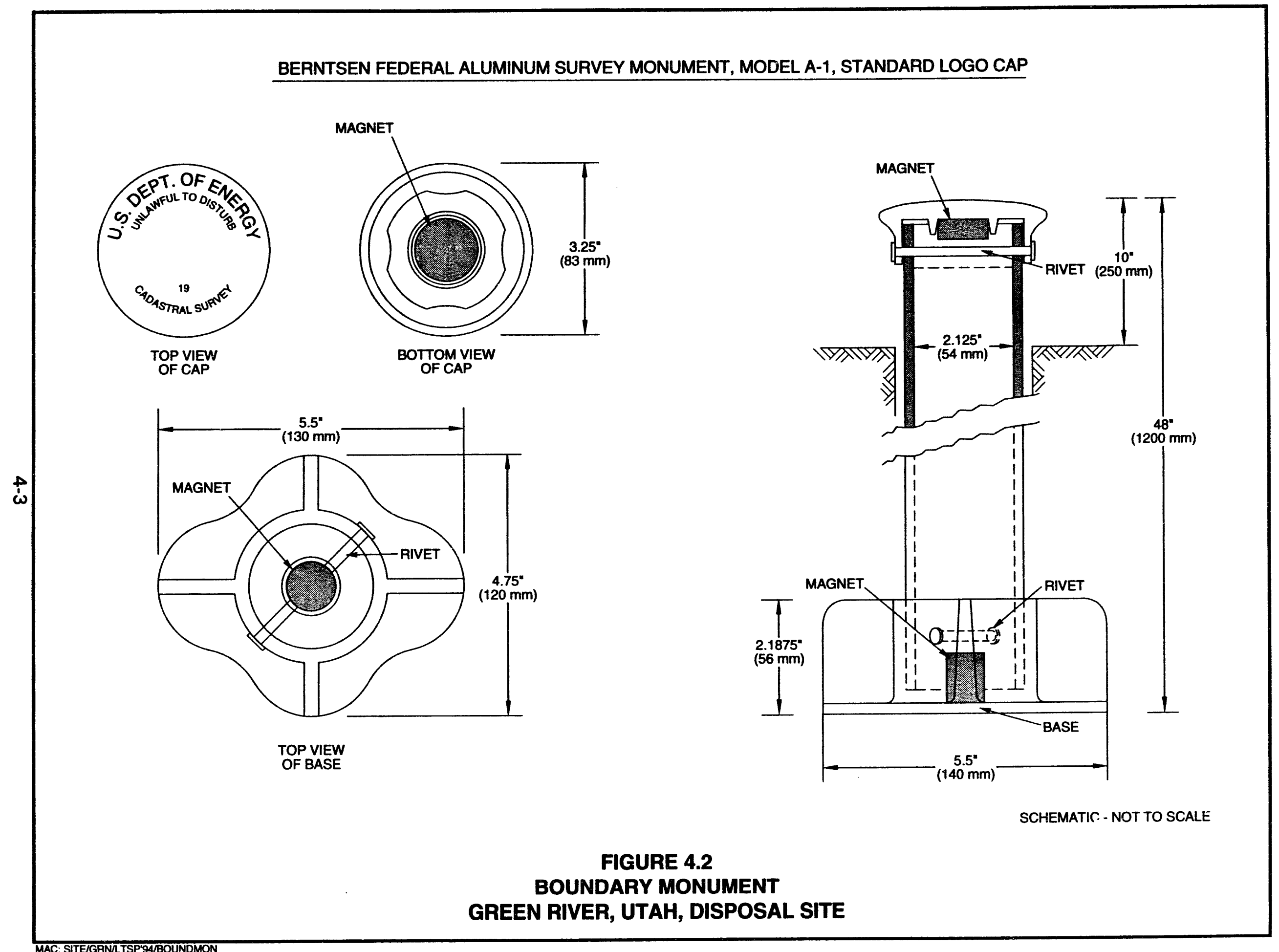



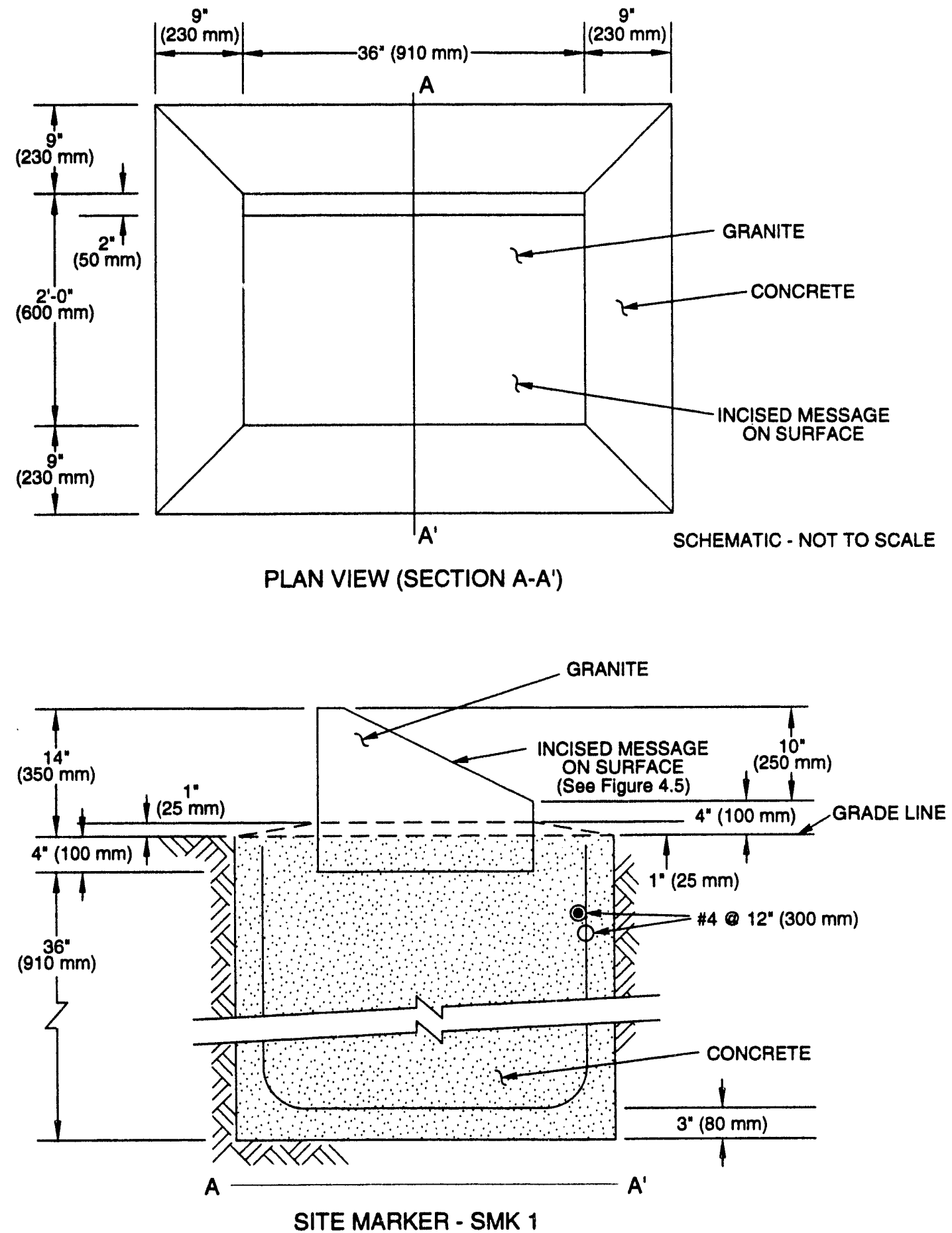

FIGURE 4.3

ENTRANCE SITE MARKER (SMK 1) AT THE GREEN RIVER, UTAH, DISPOSAL SITE 

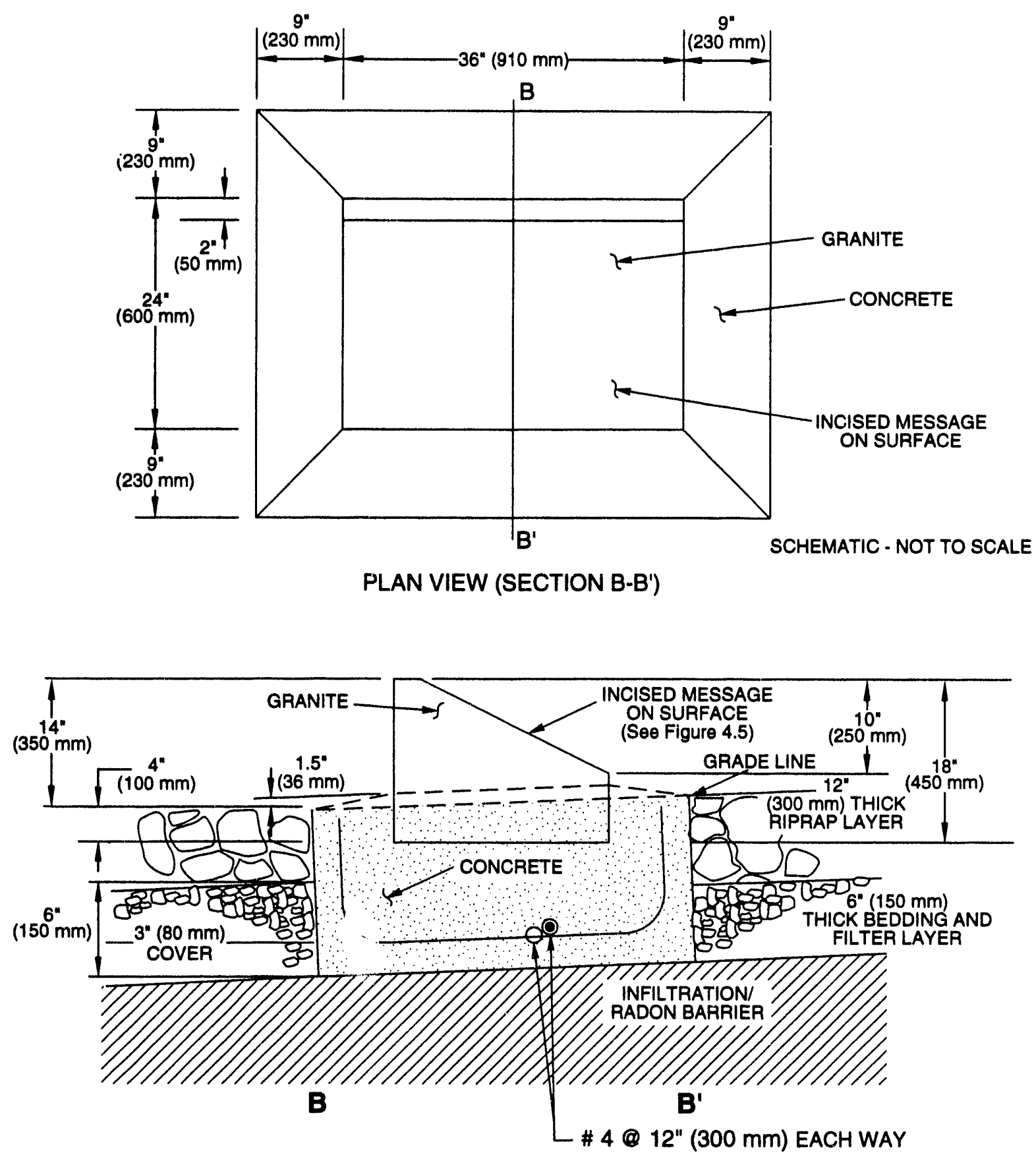

SITE MARKER - SMK 2

SCHEMATIC - NOT TO SCALE

SIDE VIEW

FIGURE 4.4

SITE MARKER (SMK 2) AT CREST OF DISPOSAL CELL GREEN RIVER, UTAH, DISPOSAL SITE 


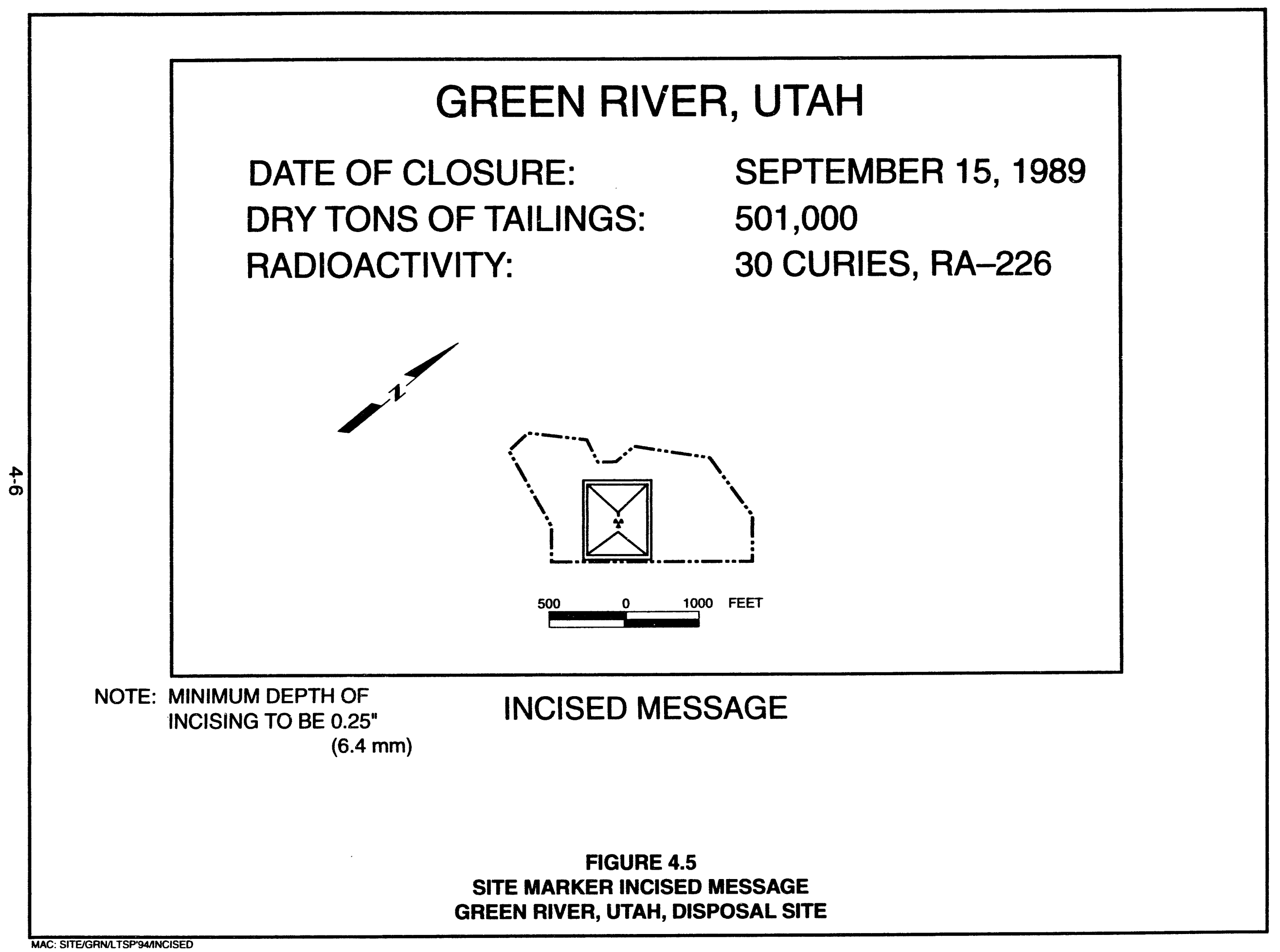


Site marker SMK-1 near the site entrance (Figure 4.3) was set in a bed of reinforced concrete that extends $3 \mathrm{ft}(1 \mathrm{~m})$ below ground surface. Site marker SMK-2 at the crest of the disposal cell (Figure 4.4) was set in a bed of reinforced concrete that extends to the top of the radon barrier. Site marker SMK-2 was excavated and set carefully to minimize disturbance of the surrounding riprap and underlying material.

\subsection{ENTRANCE AND PERIMETER SIGNS}

Eighteen perimeter signs mounted on steel posts were placed at intervals around the site. These signs display the international symbol indicating the presence of radioactive materials. They also state that the disposal site is government property, that it contains uranium mill tailings, and that trespassing is forbidden (Figure 4.6). The perimeter sign at the site entrance (Figure 4.7) also displays the name of the site and the names and telephone numbers of the DOE and the state of Utah Department of Health, Bureau of Radiation Control. The sign will require updating whenever these telephone numbers change.

The signs were constructed according to the dimensions and specifications shown in Figures 4.6 and 4.7. The tops of the signs are 70 inches $(180 \mathrm{~mm})$ above ground surface; the posts were embedded a minimum of 38 inches $(970 \mathrm{~mm}$ ) below ground surface into a concrete footing (minimum $1 \mathrm{ft}[0.3 \mathrm{~m}]$ diameter).

\subsection{SETTLEMENT PLATES}

The total long-term settlement of material in the disposal cell is expected to be very small because the materials were compacted during placement. Settlement of the bedrock foundation will be negligible. Therefore, the potential hazards of settlement, including differential settlement-induced cracking of the infiltration/radon barrier, are considered acceptably small, and settlement plates are not required.

\subsection{ADDITIONAL SITE SURVEILLANCE FEATURES}

Because the main channel of Brown's Wash is not expected to migrate toward the disposal cell, and all existing gullies in the vicinity of the site were filled and graded, additional site surveillance features such as erosion control markers are not required. Where erosion, channel migration, slope retreat, or other slopemodifying processes are active, appropriate measurements, photographs, and notes should be taken to establish the approximate rate and extent of erosion or slope failure.

\subsection{REFERENCE POSTS}

Because permanent features are unobstructed, reference posts were not required at this site and therefore were not installed. 


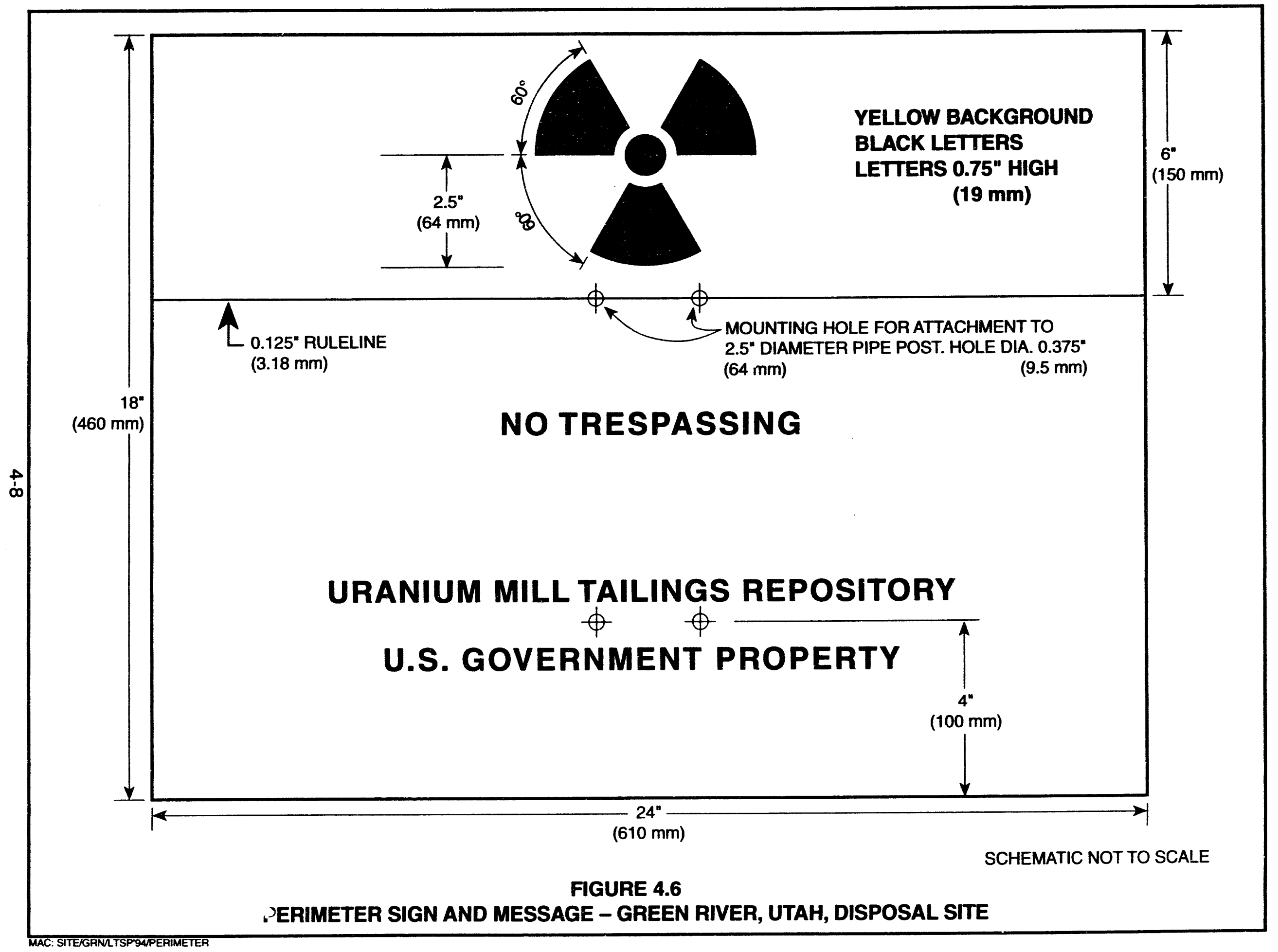




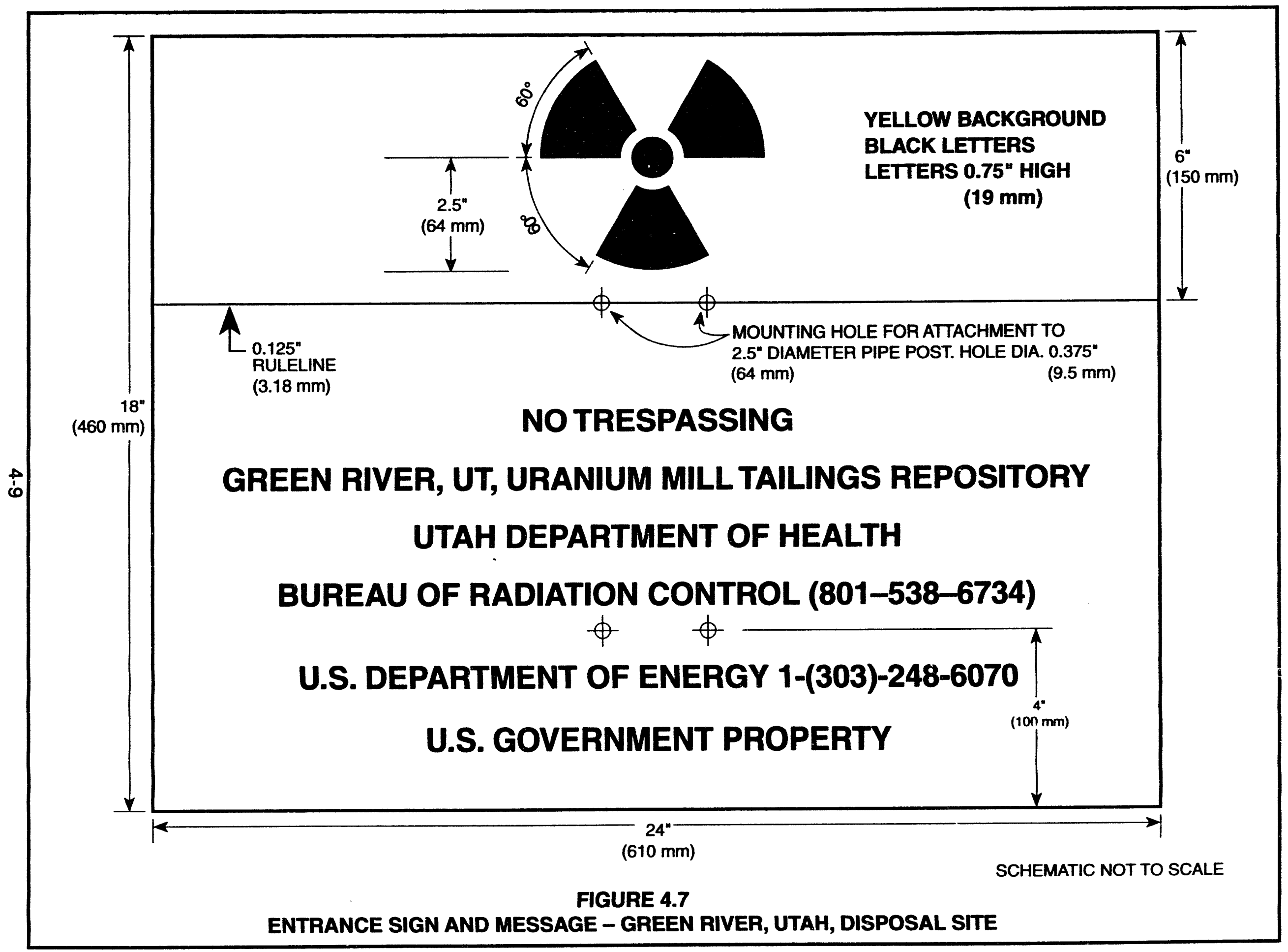




\subsection{GROUND WATER MONITORING}

NRC regulations in 10 CFR $\$ 40.27$ (b) (1994) require that the disposal site LTSP describe existing ground water conditions and any ground water activities or strategies that may be required at the disposal site to satisfy the EPA proposed standards (52 FR 36000) (1987). The DOE will comply with the published proposed standards until the final standards take effect. The final rule for comment has been prepared but not published (EPA, 1991). When appropriate, an addendum to this LTSP will reference the requirements of the final standards.

A ground water monitoring program is necessary for the UMTRA Project Green River disposal site. Ground water monitoring for cell performance began in August 1990, after the disposal cell was completed. The criteria for establishing a ground water monitoring program are set forth in 52 FR 36000 (1987). The ground water monitoring program will be carried out over a specified period of time adequate to demonstrate that the initial performance of the disposal cell is in accordance with the design requirements.

The DOE ground water protection strategy for Green River is based upon compliance with the proposed EPA ground water protection standards. This will be accomplished by applying supplemental standards at the Green River disposal site based on the presence of Class III (limited use) ground water in the uppermost aquifer due to widespread natural ambient contamination (40 CFR $\$ 192.21$ (g) (1994)). Ground water in the uppermost aquifer (saturated sandstone, siltstone, limestone, and shale of the Cedar Mountain Formation) is not a current source of drinking water because of the presence of widespread, ambient concentrations of naturally occurring selenium, sulfate, and total dissolved solids (TDS) not due to activities involving RRM from the former processing site that cannot be cleaned up using treatment methods reasonably employed in public watersupply systems (40 CFR \$192.11(e)(2) (1994)).

\subsection{GROUND WATER CHARACTERIZATION}

The DOE has characterized the hydrogeologic units, aquifer hydraulic and transport properties, tailings materials, and geochemical conditions of the Green River disposal site. This information is summarized in the following subsections. Details of the hydrogeologic site characterization are provided in the RAP (DOE, 1991), RAP modification no. 2 (DOE, 1994) and the EA (DOE, 1988).

\subsubsection{Hydrostratigraphy}

Within the upper $200 \mathrm{ft}(60 \mathrm{~m})$ of Quaternary and Cretaceous sediments, three distinct water-bearing units were defined at the UMTRA Project Green River site (DOE, 1991): 1) the top hydrostratigraphic unit (alluvium); 2) the middle hydrostratigraphic unit, comprising the upper portion of the Cedar Mountain Formation; and 3) the bottom hydrostratigraphic unit, comprising the Buckhorn member of the lower Cedar Mountain Formation. The Dakota Sandstone is present in some areas beneath the disposal site. The hydrostratigraphic units are underlain by the Jurassic Morrison Formation. 
The top hydrostratigraphic unit is absent under the disposal site and will not be discussed in this report. The middle hydrostratigraphic unit of the Cedar Mountain Formation makes up the uppermost aquifer at the disposal site.

\section{Ground water}

Ground water in the uppermost aquifer (the Cedar Mountain Formation) is first encountered at a depth of about $60 \mathrm{ft}(18 \mathrm{~m})$ beneath the disposal site. Ground water flow is controlled by connected fractures and joints; strong, upward vertical hydraulic gradients; and the attitude (dip) and lateral extent of the hydrostratigraphic units (DOE, 1991). Ground water in the Cedar Mountain Formation moves under a lateral hydraulic gradient, ranging from 0.002 to 0.075 , and trending north-northwest, as shown in Figure 5.1. An upward vertical hydraulic gradient of 0.55 was calculated for the Cedar Mountain Formation beneath the disposal site.

\section{Surface water}

Surface water features in the vicinity of the Green River site include the Green River, Brown's Wash, and an intermittent stream (DOE, 1991). The site is approximately $0.5 \mathrm{mi}(0.8 \mathrm{~km})$ east of the Green River, which drains southward and southeastward from the site area and joins the Colorado River 60 air mi (100 air $\mathrm{km}$ ) south of the site. Brown's Wash, an intermittent tributary of the Green River, is located approximately $900 \mathrm{ft}(300 \mathrm{~m})$ north of the disposal site. The wash has a drainage area of $52 \mathrm{mi}^{2}\left(140 \mathrm{~km}^{2}\right)$ in the site vicinity. Small gullies direct runoff from the disposal site northwest to Brown's Wash and eventually to the Green River. The disposal area is not susceptible to flooding of either the Green River or Brown's Wash.

\subsubsection{Background ground water quality}

Historical background ground water quality data for the Cedar Mountain Formation (uppermost aquifer) underlying the Green River disposal site, collected through December 1993, are available at the UMTRA Project Office. Three background monitor wells were sampled intermittently over 1 to 3 years prior to remedial action construction activities to determine background ground water quality at the disposal site. Detailed information about the background monitor wells is provided in the Green River RAP (DOE, 1991).

Water quality in the Cedar Mountain Formation (uppermost aquifer) is characterized as a sodium-sulfate type, with high TDS (ranging from 6220 to 7620 milligrams per liter [mg/L]) and neutral pH (ranging from 6.9 to 7.6). Concentrations of hazardous constituents and indicator parameters are highly variable in the Cedar Mountain Formation (DOE, 1991; NRC, 1990). These variations in water chemistry result from stratigraphic variations and fracturing, which create differences in the hydrogeochemical flow paths. 


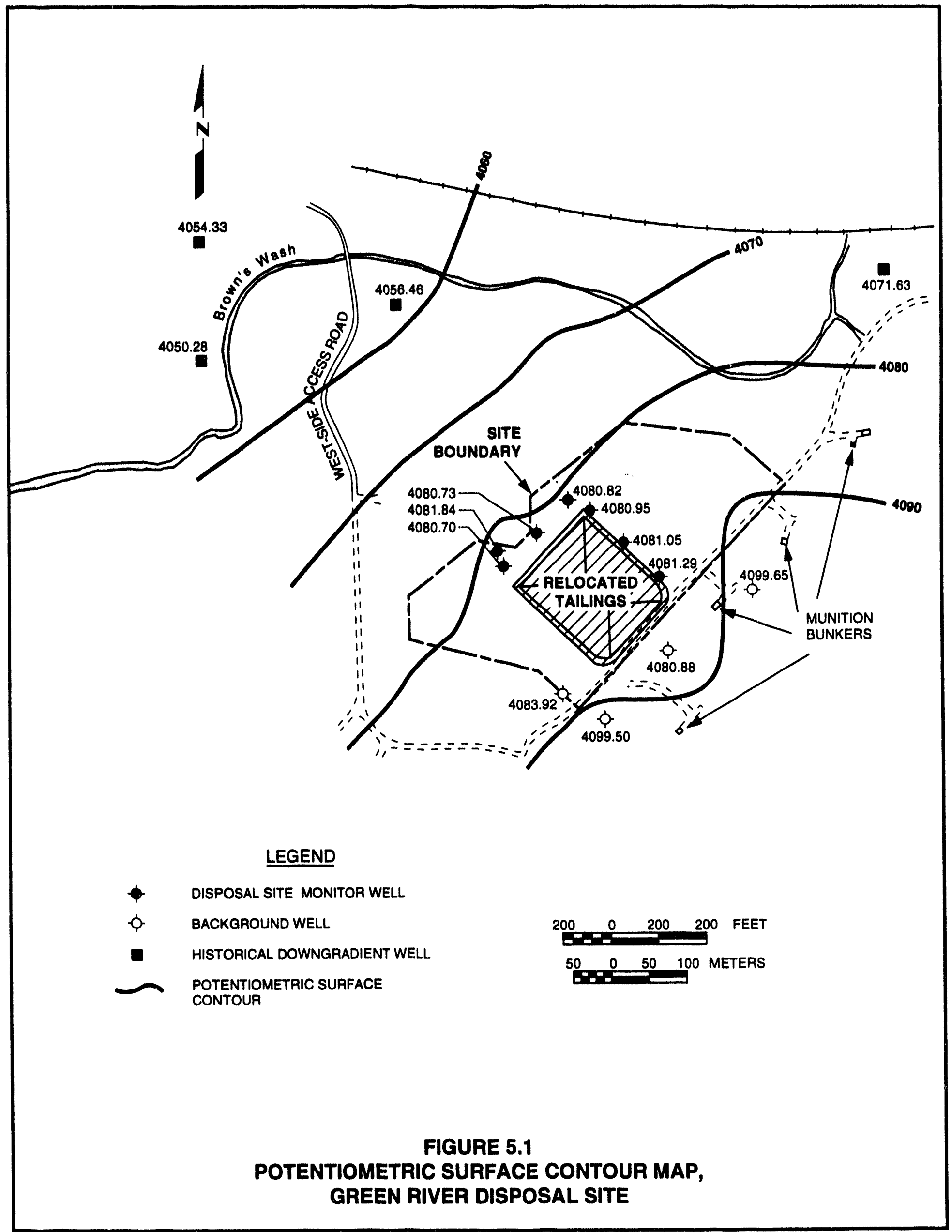


During site characterization, described in detail in the Green River RAP IDOE, 1991), background ground water quality was analyzed for hazardous constituents listed in Appendix IX to 40 CFR Part 264 (1994), plus additional constituents listed in the modifications to Table A in 40 CFR Part 192 (52 FR 36000 (1987)). MCLs proposed by the EPA (1991) for ground water are listed in Table 5.1.

Ground water quality measurements have exceeded MCLs for arsenic, cadmium, chromium, molybdenum, net gross alpha, nitrate, radium-226 and -228 , selenium, and uranium. These high levels are indicative of naturally high background concentrations and/or contamination from sources other than mill tailings and RRM and do not relate to tailings seepage. The disposal site is approximately $600 \mathrm{ft}(180 \mathrm{~m})$ upgradient of the processing site.

Four disposal site monitor wells were installed upgradient of the completed disposal cell in 1990. Concentrations of arsenic, molybdenum, net gross alpha, nitrate, selenium, uranium, and radium-226 and -228 activity have exceeded the MCLs in these monitor wells.

The background ground water quality of the Cedar Mountain Formation has been classified as Class III because concentrations of selenium exceed the Title I $\mathrm{MCL}$ in zones of the uppermost aquifer not affected by milling activities. Class III ground water includes water that is not a current or potential source of drinking water because widespread, ambient contamination exists (not due to activities involving a designated processing site) that cannot be purified using treatment methods reasonably employed in public water supply systems 140 CFR $\$ 192.21$ (g)). Elevated concentrations of arsenic, molybdenum, nitrate, uranium, and net gross alpha and radium-226 and -228 activity are also found in the uppermost aquifer.

\subsubsection{Monitored constituents and concentration limits}

The EPA ground water protection regulations (40 CFR $\$ 192.02$ (1994)) consist of three components: 1 ) identification of the hazardous constituents within the disposal cell; 2) proposal of a concentration limit for each constituent; and 3) specification of a point of compliance (POC). These three components are described in the Green River RAP (DOE, 1991) and are summarized below.

\section{Identification of hazardous constituents}

The hazardous constituents listed in Table 1, Appendix I to 40 CFR Part 192 (1994), and Appendix IX to 40 CFR Part 264 (1994) were tested to help characterize the Green River tailings materials. The tailings materials are described and the tailings pore fluid solution is evaluated in the Green River RAP (DOE, 1991). Ten hazardous constituents (from Appendix IX of 40 CFR Part 264 (1994)) were identified from analyses of tailings pore water (DOE, 1991): cadmium, chromium, molybdenum, nickel, nitrate, selenium, uranium, vanadium, radium-226 and -228 , and net gross alpha activity. In addition, arsenic and lead 
Table 5.1 Listed hazardous constituents for ground water for the UMTRA Project disposal sites (40 CFR $\$ 192.02$ (1994))

\begin{tabular}{lc} 
Arsenic & 0.050 \\
Barium & 1.00 \\
Cadmium & 0.010 \\
Chromium & 0.050 \\
Lead & 0.050 \\
Mercury & 0.002 \\
Molybdenum & 0.100 \\
Nitrate (as N) & 10.0 \\
Radium & $5.0 \mathrm{pCi} / \mathrm{L}$ \\
Selenium & 0.010 \\
Silver & 0.050 \\
Uranium (U-234 + 238) & $30.0 \mathrm{pCi} / \mathrm{L}$ \\
Natural gross alpha (excluding U + Rn) & $15.0 \mathrm{pCi} / \mathrm{L}$ \\
& \\
& \\
Endrin & 0.0002 \\
Lindane & 0.004 \\
Methoxychlor & 0.100 \\
Toxaphene & 0.005 \\
2,4-D & 0.100 \\
2,4,5-TP silvex & 0.010 \\
Benzene & 0.005 \\
Vinyl chloride & 0.002 \\
Tetrachloromethane & 0.005 \\
1,2-dichloroethane & 0.005 \\
Trichloroethene & 0.005 \\
1,1-dichloroethylene & 0.007 \\
1,1,1-trichloroethane & 0.200 \\
p-dichlorobenzene & 0.075 \\
\hline
\end{tabular}

${ }^{a} \mathrm{mg} / \mathrm{L} \quad=$ milligrams per liter.

$\mathrm{b}_{\mathrm{pCi} / \mathrm{L}}=$ picocuries per liter.

Reference: EPA, 1991 
have been added to the hazardous constituents list in response to comments from the final technical evaluation report (NRC, 1990).

\section{Hazardous constituent protection limits}

Because concentration limits for hazardous constituents at a POC are not required under a supplemental standards strategy, the hazardous constituent protection limits at the designated disposal site monitor wells for the Green River disposal site are equal to one of the following: 1) the MCL (established by the EPA), or 2) the maximum observed background concentration for a given constituent. "Background" is defined as the quality of ground water expected at the site if processing site contamination had not occurred.

Background ground water quality was determined by chemical analysis of ground water samples collected from monitor wells screened in the Cedar Mountain Formation. A summary of the background ground water quality, MCLs, and final protection limits for the designated hazardous constituents is presented in Table 5.2. The protection limits reflect the natural variability of background ground water quality in the Cedar Mountain Formation. Additional information concerning the recalculation of background ground water quality and the revised DOE protection limits is available in the final Completion Report, Volume 3, Appendix K (MK-F, 1991).

In addition to the monitored hazardous constituents, a standard suite of indicator constituents (major cations, anions, and standard field measurements) has been monitored and analyzed. Changes in concentrations for these indicators signal possible changes in the existing geochemical conditions that may influence contaminant transport. The geochemical data collected for the indicator constituents and the hazardous constituents are used to define the physicochemical environment and to monitor natural variations in the ground water system. The list of constituents recommended for long-term monitoring is provided in Table 5.3.

\section{Point of compliance monitor wells}

A POC is not required under the supplemental standards compliance strategy; however, a monitor well network is in place at the disposal site. Details and an illustration of the monitor well network are provided in Section 5.2. Ground water quality data for the disposal site monitor wells are available at the UMTRA Project Office and will be included in the Green River permanent site file.

\subsection{GROUND WATER MONITORING NETWORK}

The ground water monitoring network consists of the following:

- Four upgradient (background) monitor wells (177 through 180).

- Six new disposal site monitor wells (171 through 176), installed in 1990. 
Table 5.2 Hazardous constituents and protection limits for the Green River disposal site ${ }^{a}$

\begin{tabular}{lcclc}
\hline \multicolumn{1}{c}{ Constituent } & $\begin{array}{c}\text { Observed } \\
\text { maximum }\end{array}$ & MCLs $^{\mathrm{b}}$ & $\begin{array}{c}\text { Final DOE } \\
\text { protection } \\
\text { limits }^{\mathrm{b}}\end{array}$ \\
\hline Arsenic (As) & 0.06 & 0.05 & 0.06 (background) \\
Cadmium (Cd) & 0.026 & 0.01 & 0.026 (background) \\
Chromium (Cr) & 0.07 & 0.05 & 0.07 (background) \\
Lead (Pb) & 0.03 & 0.05 & 0.05 (MCL) \\
Molybdenum (Mo) & 0.22 & 0.1 & 0.22 (background) \\
Nickel (Ni) & 0.09 & $\ldots$ & 0.09 (background) \\
Nitrate (NO ${ }_{3}$ ) & 293 & 44 & 293 (background) \\
Selenium (Se) & 2.5 & 0.01 & 2.50 (background) \\
Uranium (U) & 0.229 & 0.044 & 0.229 (background) \\
Vanadium (V) & 0.38 & $\ldots$ & 0.38 (background) \\
Radium-226/228 (Ra) & $25.5 \mathrm{pCi} / \mathrm{L}$ & $5 \mathrm{pCi} / \mathrm{L}$ & 25.5 pCi/L (background) \\
Net gross alpha & $158 \mathrm{pCi} / \mathrm{L}$ & $15 \mathrm{pCi} / \mathrm{L}$ & 158 pCi/L (background) \\
\hline
\end{tabular}

aMonitor wells included in the analyses are GRN01-171 to -180, GRN01-561, GRN01-562, GRN01-806, GRN01-811, GRN01-813, and GRN01-816. Samples were taken before, during, and after remedial action.

bunits in milligrams per liter, unless noted otherwise.

- One preconstruction monitor well (813), downgradient and proximal to the disposal cell, installed in 1987.

Prior to remedial action construction activities, monitor well 813 was used historically to measure background water quality at the disposal site. All of the wells in the ground water monitoring network are screened in the Cedar Mountain Formation (uppermost aquifer). The locations of these wells are shown in Figure 5.2. Monitor well completion reports and lithologic logs are included in the Green River permanent site file.

Final protection limits for the designated hazardous constituents are listed in Table 5.2. Ground water level and quality data for the upgradient and disposal site monitor wells will be reviewed every 5 years at a minimum. A performance evaluation of the ground water monitoring network will be provided, based on the results of the 5-year historical data review. 
Table 5.3 List of constituents recommended for long-term monitoring

\begin{tabular}{llll}
\hline Hazardous constituents & Major ions & Indicator constituents & Field parameters \\
\hline Arsenic & Calcium & Aluminum & pH \\
Cadmium & Magnesium & Iron & Alkalinity \\
Chromium & Potassium & Ammonium & Specific conductance \\
Lead & Sodium & Silica & Temperature \\
Molybdenum & Chloride & Sulfide & Redox potential (Eh) \\
Nickel & Phosphate & Manganese & \\
Nitrate & Sulfate & Total dissolved & \\
Selenium & & solids (TDS) & \\
Uranium-234 & Total organic \\
and -238 & carbon (TOC) & \\
Vanadium & & & \\
Radium-226 & & \\
and -228 & & & \\
Net gross alpha & & & \\
\hline
\end{tabular}

\subsubsection{Monitoring network}

Monitoring of the uppermost aquifer is required under 40 CFR $\$ 192.02(a)(3)$ (1994). The direct monitor well network consists of the 11 monitor wells listed in Section 5.2. These wells are used to measure ground water quality and static water levels at and beyond the edge of the disposal cell.

The disposal site monitor wells have been placed to provide early detection of any hazardous constituents released in the uppermost aquifer without disturbing the design components of the cell. Because of the fractured nature of the Cedar Mountain Formation, wells are spaced more closely together than if the aquifer were homogeneous and isotropic. Well spacing is approximately $200 \mathrm{ft}(60 \mathrm{~m})$ along the northwest toe and northeast toe of the disposal cell. This relatively close positioning of wells is consistent with procedures outlined in the RCRA Ground-water Monitoring Technical Enforcernent Guidance Document (TEGD) (EPA, 1986). Although there is no POC at the disposal site, ground water monitoring will continue at all of the disposal site wells as a best management practice (DOE, 1994).

The four upgradient monitor wells (177 through 180) were installed approximately $200 \mathrm{ft}(60 \mathrm{~m})$ southwest and southeast of the disposal cell. Samples from these wells will be used to detect any regional changes in geochemistry over time. The placement of these upgradient wells has been optimized, as discussed in the TEGD (EPA, 1986) as follows:

- The wells have been placed beyond the upgradient extent of potential seepage from the disposal cell. 


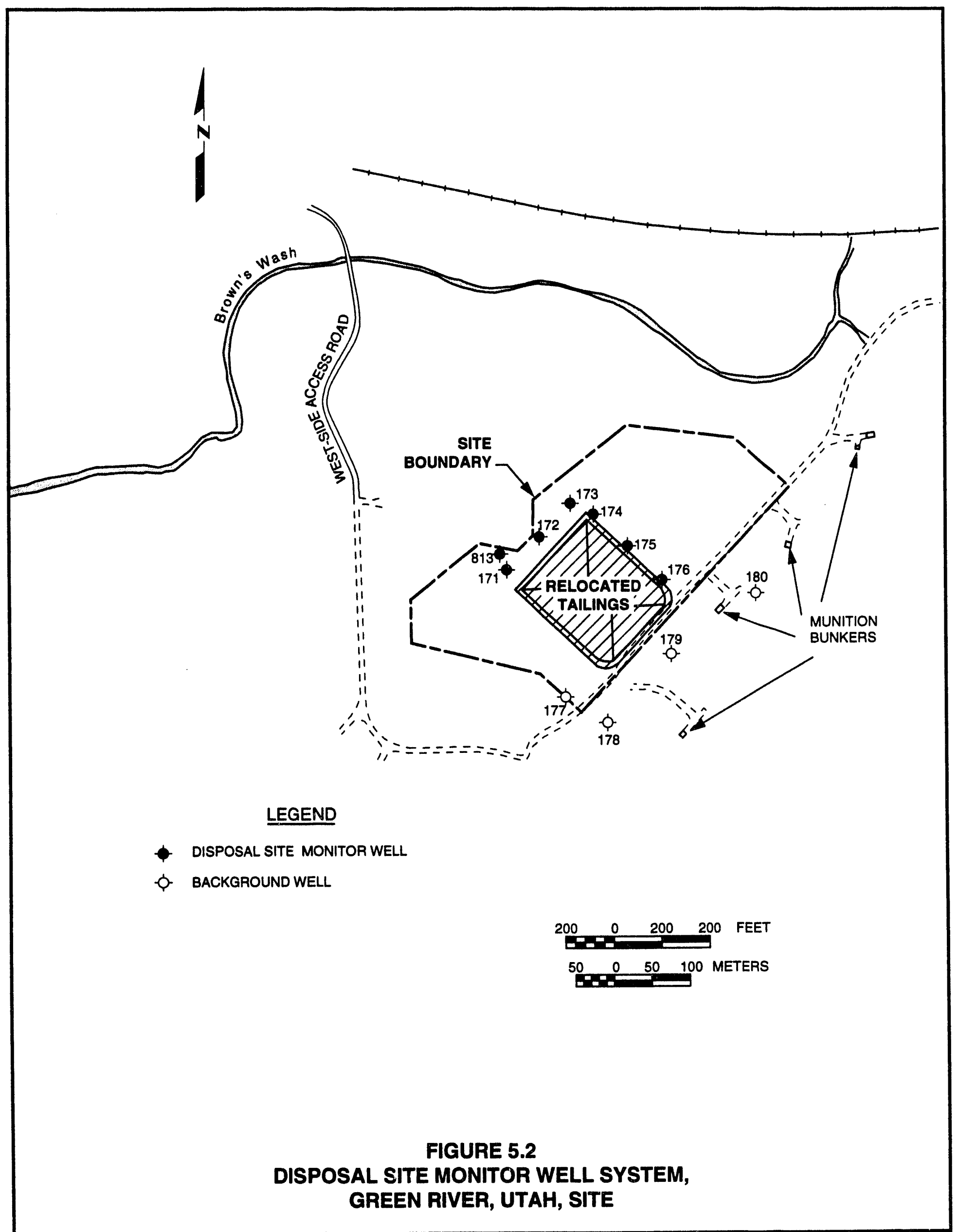


- The wells have been screened in the uppermost aquifer within the same formation and at approximately the same depths as the disposal site monitor wells.

- The wells are of sufficient number to account for heterogeneity in background ground water quality data.

- The disposal cell's surface runoff is downslope away from the upgradient monitor wells.

\subsubsection{Monitor well installation and development}

All monitor wells were installed and developed in accordance with standard operating procedures (SOP) 16.1.1 and 16.1.2, which are on file at the DOE Albuquerque Operations Office, UMTRA Project Office, Albuquerque, New Mexico (JEG, n.a.). These SOPs are as consistent as possible with the guidance in the TEGD (EPA, 1986) to ensure that representative ground water samples are obtained.

Specific information regarding monitor well installation and development is presented in the Green River RAP (DOE, 1991). Lithologic logs and monitor well completion reports are on file at the UMTRA Project Office.

\subsection{GROUND WATER MONITORING PROGRAM}

Pursuant to 40 CFR $\$ 192.02$ (a)(4)(b) (1994), this section addresses the ground water monitoring plan to be carried out after the remedial action period. The plan is designed to demonstrate that the initial performance of the disposal cell is in accordance with the design requirements.

The remedial action strategy for the Green River site involved stabilization on the site. However, ground water quality under the Green River disposal site and at the northern edges of the disposal cell does not have the potential to be degraded by the RRM or uranium milling operations for the following reasons:

- The tailings were stabilized upgradient from the uranium processing site. Processed and windblown tailings materials were moved from a floodplain of Brown's Wash approximately $600 \mathrm{ft}(180 \mathrm{~m})$ south to a plateau about $40 \mathrm{ft}$ $(12 \mathrm{~m})$ above the maximum level of flooding of Brown's Wash.

- Ground water contamination related to the uranium processing activities will not affect the relocated stabilized tailings. The Cedar Mountain Formation is the uppermost aquifer for both the former processing site and the disposal site. Ground water moves downgradient from the disposal site toward the processing site in the Cedar Mountain Formation. 
Therefore, monitoring at the Green River disposal site will follow the specifications for relocated disposal sites, provided in the LTSP guidance document (DOE, 1992a).

The DOE has completed the additional post-remedial sampling period and has recalculated background ground water quality concentrations for the designated hazardous constituents. The final protection limits are provided in Table 5.2.

If an increase above the established final protection limits is identified, the exceedance will be evaluated in accordance with the exceedance criteria identified in Section 5.3.2. If the exceedance is not related to procedural problems such as sampling or analysis, an evaluative monitoring program may be initiated to verify the exceedance and determine its cause.

The program to monitor the Cedar Mountain Formation (uppermost aquifer) consists of analyzing ground water samples from the 11 monitor wells that make up the direct monitor well network. This network is discussed in Sections 5.2 and 5.2.1.

Performance monitoring frequency is outlined in Section 5.3.1. The constituents to be monitored are listed in Table 5.3.

All aspects of the ground water monitoring program will be conducted in accordance with accepted industry quality assurance (QA) practices, including directives in DOE Orders 5700.6C, Quality Assurance, and 5400.1, General Environmental Protection Program. The general sequence for conducting the ground water monitoring program is provided in Figure 5.3.

\subsubsection{Sampling frequency}

The ground water monitoring program and the schedule for sampling are determined taking into account factors such as variations in historical background ground water quality measurements, the geochemistry of the tailings pore fluid solution, the ground water flow rate, the possibility of seasonal variations in ground water quality, and the risk to human health and the environment. Information regarding these factors is presented in the Green River RAP (DOE, 1991).

Ground water levels will be ineasured prior to sampling each well. The resulting water level data will be examined periodically to estimate the ground water flow rate and direction. This step will ensure that no significant hydrologic change has occurred that could affect ground water monitoring.

A change in sampling frequency is provided for after an evaluation of the data collected during the first 5 years following disposal cell construction (completed in 1989). Evaluation of the first 5 years of data revealed that sufficient ground water level and concentration data had been collected to establish that no significant changes in the local hydrologic setting have occurred and that 


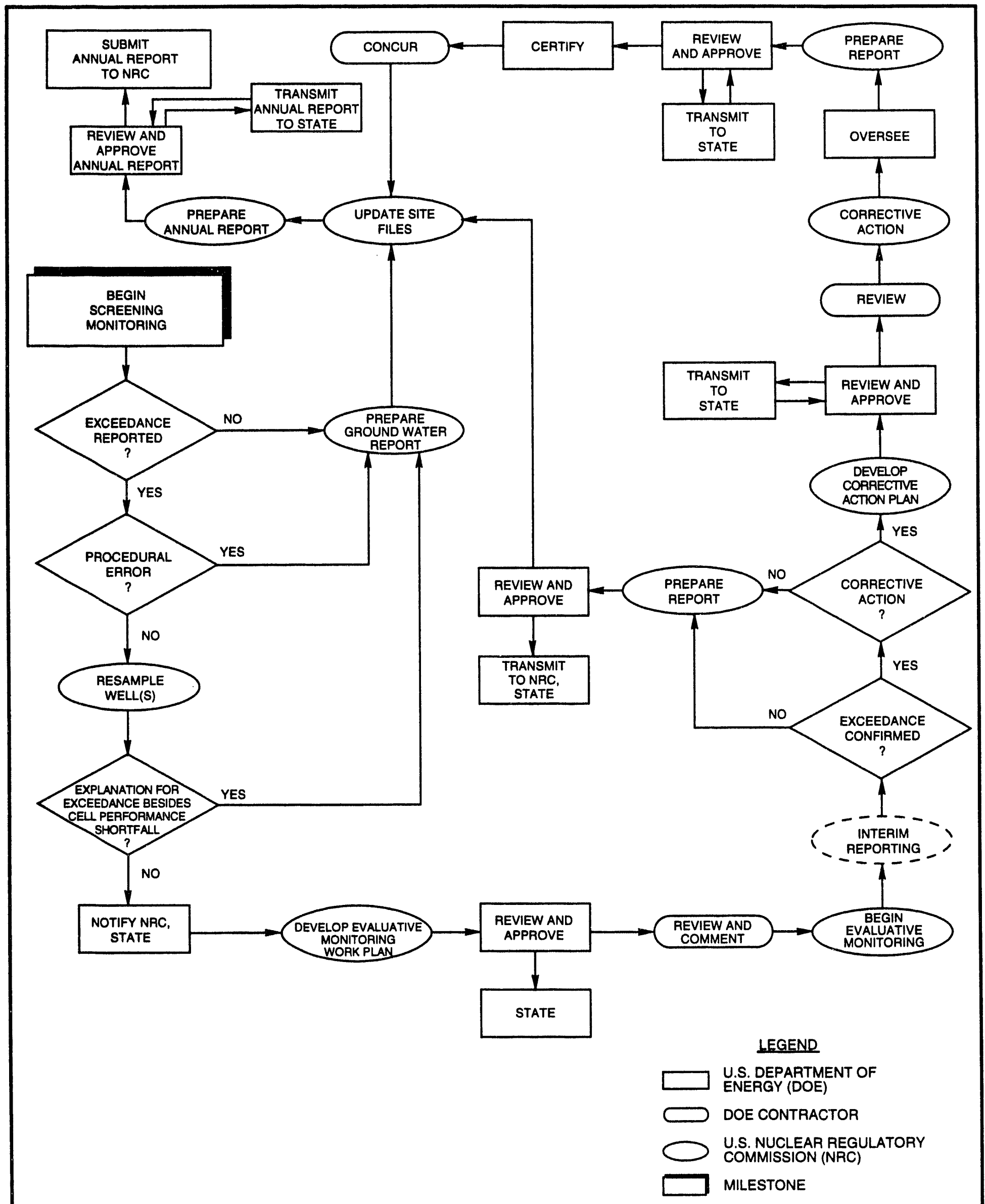

FIGURE 5.3

REF: DOE, 1992a 
reasonable concentration ranges for natural fluctuation have been established. The monitor well network (upgradient and disposal site) will be sampled annually from 1994 onward.

Performance evaluations will be conducted periodically to determine the following:

- The effectiveness of the disposal cell ground water protection strategy.

- The effectiveness of the ground water monitoring plan (i.e., ground water monitor well network, sampling frequency, analytes measured).

- The need for continued monitoring.

Monitoring data wiil be reviewed and analyzed, and recommendations will be presented in the Green River water sampling and analysis plan. This approach will provide the flexibility necessary to respond to new information and changing conditions. Performance evaluation reports will be presented to the NRC and state of Utah for comments. The statistical methods described in the EPA's Statistical Analysis of Ground Water Monitoring Data at RCRA Facilities Interim Final Guidance (EPA, 1989) or other appropriate methods will be applied as necessary.

\subsubsection{Screening monitoring and exceedance validation}

During the established ground water monitoring period, screening monitoring will be conducted to observe possible changes in ground water quality. Screening monitoring involves routine water quality data collection, data evaluation, and possible resampling. Exceedances in protection limits will be evaluated well by well and analyte by analyte. If the protection limits presented in Table 5.2 are exceeded, the appropriate steps will be taken.

\subsubsection{Evaluative monitoring}

When sampling, evaluation, and resampling performed during screening monitoring cannot rule out the disposal cell as the cause of a water quality exceedance, additional field and evaluation work (evaluative monitoring) may be required. This work will be conducted to determine with greater surety whether the disposal cell is the cause and, if so, the nature and extent of the exceedance. Evaluative monitoring will involve the procedures described in Section 5.3.3 of the Guidance for Implementing the UMTRA Project Long-term Surveillance Program (DOE, 1992a).

\subsection{CORRECTIVE ACTION}

The EPA's proposed standards (52 FR 36000 ) (1987) require that a corrective action program be implemented within 18 months after verifying that the established protection limits for one or more of the monitored constituents have 
been exceeded. The goal of the corrective action program is to restore the disposal cell to the design requirements and, as necessary, to clean up ground water in conformance with Subpart B. NRC regulations (10 CFR $\$ 40.27$ (c)(5)) (1994) specify that the DOE will notify the NRC before implementing any significant action(s) that may be required. Section 9.0 provides guidance for implementing a corrective action program.

If corrective action is deemed necessary, the DOE will prepare and submit a corrective action plan to the NRC for review. A copy of this plan also will be sent to the state of Utah. The corrective action plan will include a monitoring program to demonstrate the effectiveness of the corrective action. The DOE will implement the corrective action after consulting with the NRC and the state of Utah.

As a part of evaluative monitoring, a risk assessment may be performed to evaluate potential harm to human health or the environment. According to the RAP, any exceedance of the proposed protection limits during the early stages of performance monitoring at the northwest and northeast edges of the disposal cell would likely be a result of the drainage of water applied to the tailings during construction. Direct ground water quality monitoring, conducted since the disposal cell has been built, has not shown any indications of significantly increased concentrations of hazardous constituents. The need for aquifer restoration at the Green River site will be addressed in a separate process to comply with Subpart B of the final EPA ground water standards (DOE, 1991).

\subsection{DATA VALIDATION AND QUALITY ASSURANCE}

The UMTRA Project has established SOPs for monitor well installation; monitor well development; water sampling, preservation, and transport; and chain of custody.

$\mathrm{QA}$, quality control $(\mathrm{QC})$, analytical data management, and validation will be detailed in a QA implementation plan (DOE, 1994b), which has been developed in accordance with DOE Order 5700.6C.

The long-term surveillance program for the Green River disposal site will remain the responsibility of the UMTRA Project Office until the Green River UMTRA Project site is licensed, at a minimum. Until licensing, all aspects of ground water monitoring will be conducted in accordance with these procedures and will be updated regularly to reflect changes in industry standards, best management practices, or guidance from the EPA. The QA procedures described in this section are consistent with the TEGD (EPA, 1986).

Upon licensing, the GJPO will be responsible for establishing procedures and developing a QA/OC program that is consistent with EPA guidance (Section 12.0). 
Sections 5.6.1 through 5.6.4 in the Guidance for Implementing the UMTRA Project Long-term Surveillance Program (DOE, 1992a) summarize standard QA procedures that will be followed for water sampling, analytical $Q C$ and $Q A$, and analytical data validation.

\subsection{REPORTING}

Final protection limits for the Green River disposal site, based on updated background water quality data and EPA standards, will be provided once they become available. These updated final protection limits will become the criteria for ground water protection at the disposal site, upon concurrence from the NRC and state of Utah.

The data and results of the ground water monitoring program will be reported annually to the NRC (Section 10.0). The following information will be included in the Green River LTSP annual monitoring report:

- A table of protection limits for hazardous constituents.

- A table comparing water quality to protection limits.

- Water quality or water level data.

- A summary of any exceedances of protection limits and the exceedance validation criteria.

- A summary of any resampling, trends, exceedances, evaluative monitoring, or corrective actions required during the reporting period.

- Any significant trends or anomalies in the water quality and water level data. The narrative will include a comparison of collected data to preestablished baseline values.

- Any significant changes in the local hydrology.

- The methods for interpreting water quality or indirect monitoring data trends.

- The qualitative or statistical procedure selected to compare ground water analyses with preestablished baseline values.

- A discussion of any new wells that may have been installed, including the rationale for their installation and all completion data.

- All completed field and laboratory forms.

In addition to the annual monitoring reports, 5-year performance evaluation reports will be provided for the Green River disposal site. The purpose of these 
status reports will be to evaluate the effectiveness of the disposal cell. The 5year performance evaluation reports will, at a minimum, include the following:

- A historic review of monitoring data.

- Summaries of water level and water quality trends.

- Statistical analyses of historical data, as necessary.

- An evaluation of the disposal cell's effectiveness.

- A determination of the effectiveness of the ground water monitoring plan and whether the plan should be modified.

- A determination of whether the remedial action is complete.

The UMTRA Project Office will submit these reports to the NRC and state of Utah in compliance with the environmental monitoring requirements of DOE Order 5400.1. All ground water monitoring data and supporting documentation will be part of the Green River permanent site file. The UMTRA Project Office will be responsible for preparing these reports until responsibility for the site is transferred to the GJPO. 


\subsection{SITE INSPECTIONS}

The three types of site inspections are as follows:

- Annual or scheduled site inspections.

- Follow-up inspections.

- Contingency inspections.

Each site inspection must be documented by a report on the findings of the inspection. Copies of the report must be forwarded to the NRC, the state of Utah, and the Green River permanent site file. Annual or scheduled site inspection reports are to be completed and filed within 90 days after the last annual (or scheduled) site inspection in that calendar year. Follow-up and contingency inspection reports are to be completed and filed within 60 days after the inspection.

\subsection{INSPECTION FREQUENCY}

The Green River disposal site will be inspected annually for the first 5 years following licensing. At the end of the 5-year period, the GJPO will evaluate the need to continue conducting annual inspections. The recommendation will be based on an evaluation of the annual reports and any other reports that have been filed due to the need for maintenance or unscheduled events. If it is determined that inspections are required less frequently, the GJPO will modify the LTSP and submit it to the NRC for acceptance. The state of Utah will also receive copies for review. Subsequent inspections would be considered scheduled site inspections.

\subsection{INSPECTION TEAM}

The inspection team will consist of a chief inspector and one or more assistants. The chief inspector will be a geotechnical engineer, a civil engineer, or an engineering geologist knowledgeable in the processes that could adversely affect the site (e.g., identifying geomorphic agents of change). Where necessary, the team will include additional technical experts appropriate to the problems under investigation.

\subsection{PREPARATION FOR INSPECTION}

Before conducting an inspection, inspectors will complete the following tasks:

- Review the final LTSP, the Green River permanent site file, previous site inspection report(s) and site inspection map(s), and any maintenance or corrective action reports.

- Prepare a site inspection checklist based on previous inspections or repairs; incorporate any modifications that may be needed. 
- Verify and update the names and telephone numbers of all parties with whom access or notification agreements have been executed.

- Verify the DOE 24-hour telephone number and appropriate agency telephone numbers and contacts. Arrange to change the entrance sign as needed.

- Schedule the site inspection.

- Notify the state of Utah and the NRC that an inspection will be conducted. Determine whether any local or state concerns need to be addressed during the site inspection.

- Assemble the equipment needed to conduct the inspection.

\section{$6.4 \quad$ SITE INSPECTION AND INSPECTION CHECKLIST}

The site inspection will cover the disposal site area, the disposal cell, and the immediate off-site areas. All site inspection activities and observations are to be recorded and described using the as-built drawings, initial site inspection checklist (Attachment 5), site inspection map, a field notebook, and photographs. Observations and photographic stations should be recorded on the field maps. After the inspection is complete, these maps are to be drafted and retained in the Green River permanent site file.

The initial site inspection checklist (Attachment 5 ) is a guideline for the inspectors during their inspection. At the completion of each inspection, the checklist will be revised to include new information or to delete items that are no longer pertinent. Revisions to the checklist will be documented in the inspection report.

A photographic record of the site inspection must be maintained. Site conditions are to be documented by ground photographs to provide a record of developing trends and to enable the DOE to evaluate the need for and extent of future activities. Any site feature or condition that requires the inspectors to make a written comment, explanation, or description will be photographed, if possible. A site inspection photo log will be used to record the photographs (Attachment 4). All features will be photographed and recorded as specified in Section 3.4. The number of photographs, the view angles, and the lenses used are up to the judgment of the inspectors, as long as sufficient photographs are taken for agency review.

\section{Off-site areas}

The area within $0.25 \mathrm{mi}(0.40 \mathrm{~km})$ of the disposal site perimeter will be surveyed for the following:

- Evidence of land use changes indicating increased human activity that could increase the probability of intrusion onto the site. 
- New roads or paths, changes in vegetation patterns, or relevant geomorphic features (e.g., stream channels or gullies) that could initiate site-threatening erosion.

\section{On-site areas}

The most effective way to inspect the Green River disposal site area and disposal cell is with a series of well-planned traverses around the entire perimeter of the disposal site and along the base of the disposal cell, diversion channels, sideslopes, and crest of the disposal cell. The number of traverses along the sideslopes will be determined by the height of the disposal cell. As a rule of thumb, the sideslope traverses should be spaced at 50-yd $(46-\mathrm{m})$ intervals. The traverses across the crest of the disposal cell should be diagonal to the long axis of the crest. At a minimum, the disposal site perimeter and site area traverses should be selected to observe damage or disturbance to the following features:

- Site perimeter roads.

- Fences, gates, and locks.

- Permanent site surveillance features.

- Ground water monitor wells and other monitoring points.

- Other instrumentation or surveillance features.

Traverses along the engineered components (diversion ditches, cell sideslopes, cell crest, and cover) should be walked along their complete length and examined for evidence of the following:

- Structural instability due to differential settlement, subsidence, cracking, sliding, or creep.

- Erosion as evidenced by the development of rills or gullies.

- Sedimentation or debris.

- Rapid deterioration of rock caused by weathering or erosion.

- Removal of rock or other disposal cell material.

- Seepage.

- Intrusion (inadvertent or deliberate) by humans or burrowing animals.

- Vandalism.

- Development of trails from human or animal activity.

- Volunteer plant growth, especially on the disposal cell or in the diversion channels. 


\subsubsection{Modifying processes}

Modifications of the disposal cell due to natural processes will be noted and recorded by the inspection team. Changes in the disposal cell will likely occur on the lower sections of the sideslope and around the toe apron.

Specific problems that can occur on the Green River disposal cell are as follows:

- The formation of gullies near the disposal cell.

- The loss of soil due to sheet erosion around the toe apron or undercutting of the disposal cell apron.

- Plant growth on the disposal cell sideslopes.

- Migration of the main channel of the off-site diversion ditch (located immediately south of the disposal cell).

- Removal of erosion protection rock or other cover material.

- Void spaces in rock layers filling with fine-grained material carried by wind or water.

\subsubsection{Vegetation}

The area around the tailings embankment is graded to the north so that runoff will flow toward Brown's Wash. Graded areas were reseeded with droughttolerant plants. Observations in 1991 indicated that the revegetation effort was a failure in that very little growth of seeded species was observed. There was, however, a dense growth of Russian thistle with an estimated vegetative cover of 24 percent (DOE, 1992b). It is expected that native species will slowly reinvade this disturbed ground over a period of a few years and that Russian thistle will remain the dominant species for years.

Only one plant was observed growing on the disposal cell in 1991; it is assumed that the rate of plant invasion of the cell will be very slow given the nature of the rock cover (DOE 1992c). Plant growth on the disposal cell, if any, will be described in the annual inspection reports.

\subsection{SITE INSPECTION MAP}

A new site inspection map will be prepared following each scheduled inspection using the disposal site map (Plate 2) as a base. The site inspection map will include the following:

- Inspection traverses.

- Photograph locations.

- Locations and descriptions of new, anomalous, or unexpected features. 
- Features identified during previous inspections for observation or monitoring.

- Date of inspection.

\subsection{REPORTING REQUIREMENTS}

Upon completion of the field inspection, Section $D$ of the initial site inspection checklist (Attachment 5) must be completed and the certification statement signed. Overlays for the as-built drawings or revised drawings should be developed, noting any potential problems or other site conditions that may require future attention. The revised drawings should be labeled with the type of site inspection and the date the site inspection was performed.

All photographs must be logged on a site inspection photo log (Attachment 4). A separate photo log should be completed for each roll of film exposed, with an entry made for each photograph. The completed photo logs are to be attached to the inspection checklist.

A site inspection report with the following information will be completed after every routine site inspection:

- Narrative of site inspection, results, conclusions, and recommendations.

- Site inspection checklist and any relevant supporting documentation.

- Site inspection map and other drawings, maps, or figures, as required.

- Inspection photographs and photo log sheet (Attachment 4).

- Recommendations for additional follow-up inspections, repair, or custodial maintenance, if required.

- Follow-up or contingency inspection reports, if required.

- Custodial maintenance or repair report and certification, if required.

- Inspection certification.

- Ground water monitoring data and analyses, if applicable.

Appendix A, Criterion 12 of 10 CFR Part 40 (1994) requires that the DOE submit the results of all routine site inspections to the NRC within 90 days of the last UMTRA Project site inspection for that calendar year. A copy of all site inspection reports will be maintained in the Green River permanent site file. A copy of the inspection report will also be sent to the state of Utah. 


\subsection{UNSCHEDULED INSPECTIONS}

Unscheduled inspections arise from reports or information indicating that site integrity has been or may be compromised. The need for an unscheduled inspection may be triggered by any of the following:

- Findings from an annual or scheduled site inspection.

- Other site visits, such as for ground water sampling, special studies, corrective action, or other DOE activities.

- Reports from law enforcement agencies or the public.

- Reports from the Earthquake Early Warning Service or the National Weather Service (NWS).

\subsection{FOLLOW-UP INSPECTIONS}

Follow-up inspections are unscheduled inspections conducted to investigate and quantify specific site problems detected during a scheduled inspection, ground water sampling event, special study, or other DOE activity. They assess whether processes currently active on or near the site pose any future threat to the site if left unchecked and evaluate the need for custodial maintenance, repair, or corrective action.

Follow-up inspections should be made by technical specialists in the discipline appropriate to the problem that has been identified. For example, if erosion is the problem, the inspector(s) should be knowledgeable in evaluating erosion processes (such as a soils scientist or geomorphologist). If settlement or sliding is the problem, a geotechnical engineer would be the appropriate inspector.

The first step of the follow-up procedure is an on-site visit to determine the need for definitive tests or studies. Additional visits may be scheduled if more data are needed to draw conclusions and recommend corrective action.

After the follow-up inspection, the DOE will analyze the information gathered; assess the situation; prepare an inspection report describing the site conditions; and, if necessary, outline recommendations for further action. If maintenance, repair, or corrective action is warranted, the DOE will notify the NRC, the state of Utah, and adjacent residents as specified in Section 9.0.

\section{CONTINGENCY INSPECTIONS}

Contingency inspections are unscheduled inspections ordered by the DOE when it receives information indicating that site integrity has been or may be threatened. Examples of events that could trigger contingency inspections include reports of severe vandalism, intrusion by humans or livestock, severe rainstorms or floods, or unusual events such as tornadoes or earthquakes. 
An assessment of each unusual event must be submitted to the NRC within 60 days of an initial report that damage or disruption has occurred at the disposal site (10 CFR Part 40 (1994)). The state of Utah will receive a copy of this report. At a minimum, this report must include the following:

- A description of the problem.

- A preliminary assessment of the maintenance, repair, or corrective action required.

- Conclusions and recommendations.

- Assessment data, including field and inspection data, and photographs.

- Field inspector names and qualifications.

A copy of the report and all other data and documentation will be maintained in the Green River permanent site file. The annual report to the NRC will also include the results of these contingency inspection reports. If appropriate, the annual (or scheduled) Green River site inspection report will also contain the results of these inspections.

After reviewing the preliminary inspection/assessment report, the DOE must submit a corrective action plan to the NRC for approval and to the state of Utah within 60 days as required by 10 CFR Part 40 (1994). Based on the findings of these reports, the GJPO will complete corrective action, following guidance for implementing a corrective action described in Section 9.0. 


\subsection{CUSTODIAL MAINTENANCE OR REPAIR}

Custodial maintenance will be performed as needed at the Green River disposal site. In general, the decision to conduct maintenance or repair will be based on the results of annual, follow-up, or contingency inspections.

\subsection{PLANNED MAINTENANCE}

No routine maintenance is planned for the Green River disposal site.

\subsection{UNSCHEDULED MAINTENANCE OR REPAIR}

Unscheduled custodial maintenance activities that may be required at the Green River disposal site include the following:

- Repair the gate.

- Replace the entrance sign or perimeter warning signs.

- Reestablish survey control and boundary monuments.

- Make repairs due to animal burrows on the disposal cell.

- Remove volunteer plant growth on the disposal cell or in the diversion channels.

For these types of custodial actions, the GJPO will prepare a purchase order that contains a statement of work (SOW) authorizing the repair. This SOW will include contractor qualifications.

If problems are identified that may affect the integrity of the disposal cell or compliance with 52 FR 36000 (1987), the NRC must approve any recommended, unscheduled action in advance. The action will be treated as a corrective action (Section 9.0).

\subsection{CERTIFICATION AND REPORTING REQUIREMENTS}

The following information on unscheduled maintenance or repair must be provided in the site inspection report and included in the annual report to the NRC:

- Summary of work required.

- Work order, purchase order, or SOW.

- Contractor qualifications, if applicable.

- Contractor documentation of completion of work.

- DOE certification of completion of work.

After the work is completed, the contractor must submit verification of the completed work in a written report if the action is considered significant. The DOE will inspect the site, as necessary, and review the report before certifying that all work is complete in accordance with all required specifications. Copies of all records, documentation, and certifications will be included in the Green 
River permanent site file. Copies of all relevant documentation will be included in the annual report to the NRC and will also be transmitted to the state of Utah. 


\subsection{CORRECTIVE ACTION}

If natural or unforeseen events threaten the stability of the disposal cell, a corrective action could include temporary emergency measures. In addition, the DOE would evaluate the factors that caused the problem to ensure that recurrence is minimized or avoided.

When a potential problem has been identified, the DOE will notify the NRC and the state of Utah and submit an inspection/preliminary assessment report to the NRC for review within 60 days. The preliminary assessment report will evaluate the problem and recommend the next step (e.g., immediate action or continued evaluation). After the NRC has reviewed the report and recommendations, the DOE will develop a corrective action plan for NRC approval. The DOE may combine the inspection and recommendation in one report, depending on the severity of the problem. Once the NRC approves the corrective action, the DOE will implement the plan. Figure 9.1 illustrates the general sequence of events in the corrective action process. Figure 9.2 identifies the key elements in the corrective action process.

NRC regulations do not stipulate a time frame for implementing corrective action. However, the EPA ground water regulations (40 CFR $\$ 192.02$ (c) (1994)) require that a corrective action program be placed into operation no later than 18 months after an exceedance is confirmed at a disposal cell. Assessing the extent of the problem and developing a corrective action plan will not be considered initiation of the corrective action program. Section 9.0 of the UMTRA Project LTSP guidance document (DOE, 1992a) contains details on corrective action.

\subsection{PROBLEM IDENTIFICATION}

Site inspections by qualified inspectors and custodial maintenance are designed to identify problems at the developmental stage, eliminating the need for corrective action. However, extreme natural events, vandalism, or unanticipated events may create the need for additional data or evaluative monitoring to assess whether uncorrected problems would threaten disposal site integrity. An on-site inspection/preliminary assessment would include, but would not be limited to, the following:

- Quantifying the nature and extent of the problem.

- Reevaluating the engineering design parameters germane to the problem.

- Establishing a data collection and/or evaluative monitoring program to quantify the magnitude of the problem.

\subsection{CERTIFICATION AND REPORTING REQUIREMENTS}

The DOE will prepare progress reports on each corrective action while it is under way or under evaluation. The NRC will be given a copy of each report, or the report will be attached to the annual report. The NRC will be informed of all 


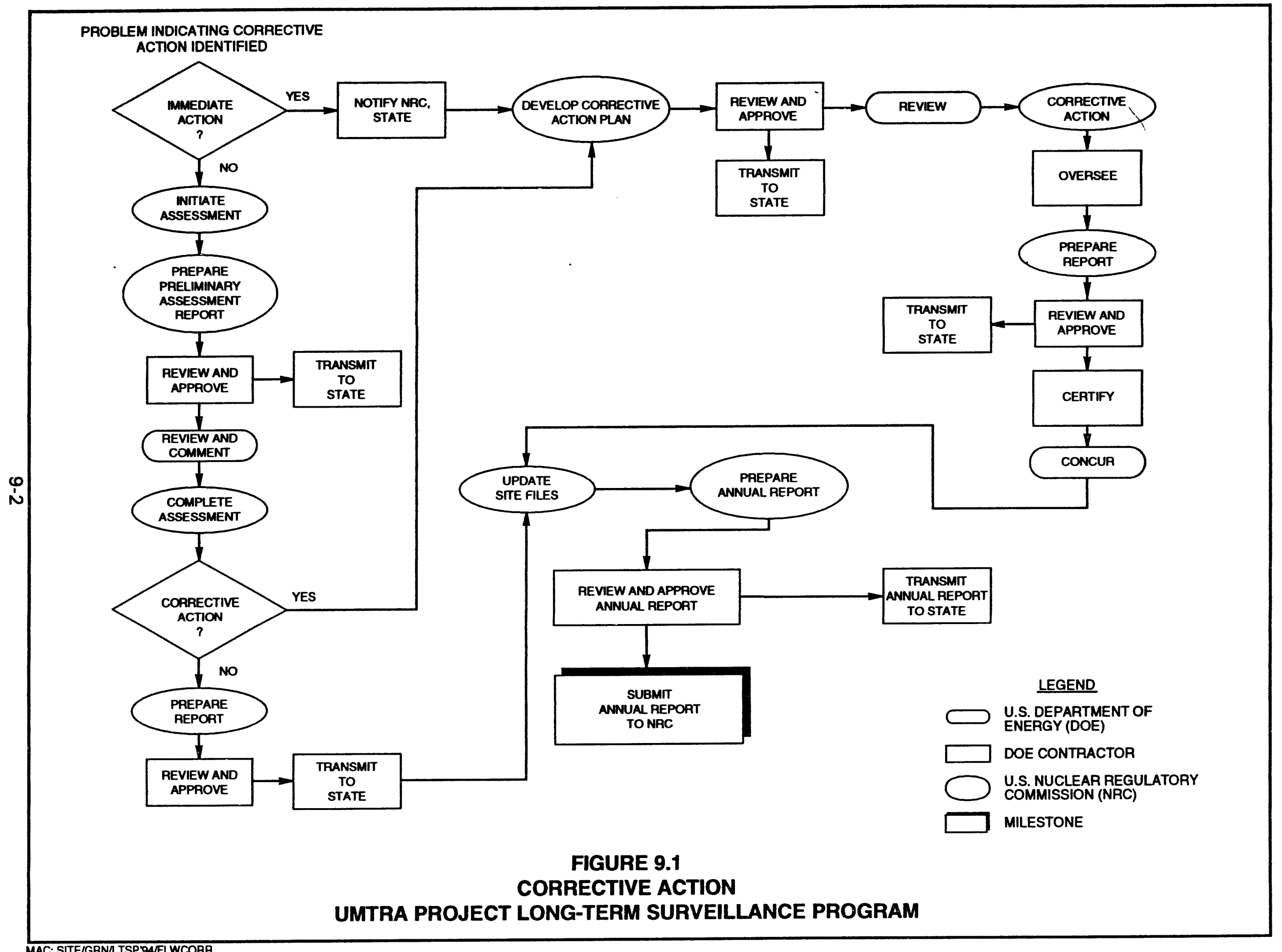




\section{NEED FOR CORRECTIVE ACTION IDENTIFIED}

DOCUMENT AND REPORT PROBLEM TO NRC, STATE, AND TRIBES

- eVAluAte problem AND pRopose a solution

- DEVELOP CORRECTIVE ACTION PLAN AND NOTIFY NRC, STATE

- SElEct CONTRACTOR to PERForm CORRECTIVE ACTION

- ESTABLISH CONTRACTUAL CONDITIONS FOR PERFORMING CORRECTIVE ACTION AND GUARANTEE CORRECTIVE ACTION WILL BE PERFORMED IN ACCORDANCE WITH CONTRACTUAL AGREEMENTS AND DESIGN SPECIFICATIONS

\begin{tabular}{|c|}
\hline IMPLEMENTATION \\
\hline MONITOR PROGRESS OF CORRECTIVE ACTION \\
VERIFY COMPLETION OF CORRECTIVE ACTION \\
\hline
\end{tabular}

\section{CERTIFICATION}

VERIFY CORRECTIVE ACTION AS DESIGNED CORRECTS THE PROBLEM

- ENSURE RECURRENCE OF PROBLEM IS MINIMIZED OR AVOIDED

- CERTIFY COMPLETION OF CORRECTIVE ACTION IN ACCORDANCE WITH 40 CFR PART 192 (1994)

- SUBMIT CERTIFICATION REPORT TO NRC

FIGURE 9.2

KEY ELEMENTS IN THE CORRECTIVE ACTION PROCESS 
potential problems and solutions. All reports will be provided to the state of Utah.

After corrective action is complete, all work completed will be certified in accordance with EPA standards. The NRC will review this certification. A copy of the DOE certification statement will become part of the Green River permanent site file, as will all reports, data, and documentation generated during the corrective action. 


\subsection{RECORD KEEPING AND REPORTING REQUIREMENTS}

The DOE will maintain the Green River permanent site file containing all information needed to prepare for and conduct site surveillance. Carefully compiled, complete, accurate reports of site surveillance activities will be maintained in accordance with archival procedures established in 41 CFR Part 101 (1994) and 36 CFR Parts 1220-1238 (1994) (Subchapter B - Records Management).

As required by 55 FR 45591 (1990), the DOE will provide an annual report to the NRC documenting the results of the long-term surveillance program. Copies of the annual report will be provided to the state of Utah and will be added to the Green River permanent site file. The annual reports and supporting documentation in the permanent site files will accomplish the following:

- Document the history of disposal site performance.

- Demonstrate to the NRC that license provisions were met.

- Provide the DOE and the NRC with the information necessary to forecast future disposal site surveillance and monitoring needs.

- Provide information to the public to demonstrate that site integrity has been maintained.

\subsection{RECORDS}

The GJPO will maintain the Green River permanent site file in Grand Junction, Colorado. All original deeds, custody agreements, and other property documents will be maintained in the DOE Facilities and Property Management Division, Albuquerque, New Mexico. Copies of these documents also will be maintained in GJPO files.

Surveillance and maintenance documentation maintained at the GJPO will exist as a record collection separate from the UPDCC. As such, the records will be handled in accordance with DOE Order 1324.2A, Records Disposition, to ensure proper handling, scheduling, and disposition of documents.

All information will be available for NRC and public review. The Green River permanent site file will include the following:

- Licensing documentation.

- The site-specific LTSP.

- Disposal site legal description, title, custody documentation, and cooperative agreements.

- Interagency agreements, authorizations, and access agreements. 
- Notification requests with the USGS, the NWS, the Emery County Sheriff's Office, and the Grand County Sheriff's Department.

- Documentation of rights of entry.

- The Green River EA and finding of no significant impact.

- The disposal site characterization report and/or processing site characterization report.

- The final RAP and final design for construction.

- Pertinent design and construction documents and drawings.

- The site certification report (certification summary, completion report, and final audit report).

- As-built drawings.

- The site atlas (vicinity, topographic, and base maps).

- Baseline and aerial photographs.

- Ground water monitoring reports and records.

- Additional monitoring reports and records.

- Monitor well permits and well abandonment records.

- Annual reports to the NRC.

- Annual inspection reports and records.

- Follow-up or contingency inspection preliminary assessments, reports, and records.

- Custodial maintenance or repair reports and records.

- Corrective action plans, reports, and records.

- The QA program plan.

Attachment 3 lists documentation that will be transferred to the GJPO for the long-term surveillance program. The GJPO will update the Green River permanent site file, as necessary, after the annual disposal site inspections are complete. Original UMTRA Project records and files will be archived with the DOE UMTRA Project Office, Albuquerque, New Mexico. Copies of the 
documentation and annual updates and additions will be kept in the Green River permanent site file held by the GJPO, Grand Junction, Colorado.

\subsection{REPORTS}

The GJPO will provide an annual report to the NRC, documenting the results of the annual site inspections and any other activities conducted in conjunction with the long-term surveillance program. Criterion 12 to Appendix A of 10 CFR Part 40 (1994) requires that the report be submitted within 90 days after the date of the last UMTRA Project site inspection for that calendar year.

The GJPO also will submit reports to the NRC documenting follow-up or contingency inspections and any corrective action plans. If any unusual damage or disruption is discovered, Criterion 12 to Appendix A of 10 CFR Part 40 $(1994)$ requires that all preliminary inspection reports be submitted within 60 days of the discovery.

The results of the ground water monitoring program will be reported annually to the NRC. The UMTRA Project Office will be responsible for preparing these ground water monitoring reports until this responsibility is transferred to the GJPO. 


\subsection{EMERGENCY NOTIFICATION AND REPORTING}

The Green River disposal cell was designed to comply with 40 CFR Part 192 (1994) with minimum maintenance and oversight for a period of 1000 years, or at least 200 years. However, unforeseen events could create problems that may affect the disposal cell's ability to remain in compliance with 40 CFR Part 192. Therefore, the DOE has requested notification from state and federal agencies of discoveries or reports of any purposeful intrusion or damage at the disposal site as well as the occurrence of earthquakes, tornadoes, or floods in the disposal site area.

\subsection{AGENCY AGREEMENTS}

The DOE has negotiated formal agreements with the Grand County Sheriff's Department and the Emery County Sheriff's Office to notify the DOE when purposeful intrusion or damage is discovered. The DOE has also arranged for the USGS National Earthquake Information Center and the NWS to notify the DOE in the event of an earthquake, a tornado, or flooding in the disposal site area (Attachment 6). These formal agreements will be updated as needed.

In accordance with the agreements, the UMTRA Project Office will be the designated facility contact until the Green River disposal site is brought under the general license. After that, the designated facility contact will be the GJPO.

Response letters from all of the agencies will be kept in the Green River permanent site file. Contact lists and telephone numbers for all agencies with whom the DOE has entered into agreements will be updated annually, in conjunction with the site inspection, for inclusion in the disposal site inspection report.

To further solidify written agreements with these agencies, the DOE GJPO will periodically contact these agencies to update them about the location of and concerns for the Green River disposal site.

\subsection{UNUSUAL OCCURRENCES}

The DOE has requested that the GJPO be notified of any unusual occurrences in the disposal site area that may affect surface or subsurface stability. The Grand County Sheriff's Department and the Emery County Sheriff's Office have agreed to notify the GJPO if anything out of the ordinary (e.g., human intrusion, fire) is observed by the staff or reported to the office (Attachment 6).

\subsection{EARTHQUAKES}

The DOE subscribes to the USGS Early Warning Service for notification when an earthquake is of sufficient magnitude to threaten a disposal site. This service provides data on the magnitude of the event and the location of the epicenter. 
The USGS National Earthquake Information Center will notify the GJPO if a seismic event(s) occurs that fits any of the following descriptions:

- Any earthquake of magnitude 3.0 or greater, within 0.3 degree labout $20 \mathrm{mi}$ [30 km]) of the site.

- Any earthquake of magnitude $\mathbf{5 . 0}$ or greater, within 1.0 degree labout $70 \mathrm{mi}$ [110 km]) of the site.

\subsection{METEOROLOGICAL EVENTS}

The DOE will complete an agreement for a continuing reporting service with the Green River office of the NWS to notify the GJPO within 8 hours of issuing a flash flood or tornado warning in Grand County, Utah. 


\subsection{QUALITY ASSURANCE}

The GJPO is responsible for developing QA procedures specific to the UMTRA Project long-term surveillance program. The GJPO QA Program Plan (DOE, 1992d) specifies the following requirements:

- Program planning.

- Program activities, including inspections, site maintenance, corrective action, and emergency response.

- Monitoring, if required.

- Personnel qualifications and training.

- Program surveillance and audits.

- Analytical QA.

- Analytical data validation.

All site inspections, monitoring data, records, photographs, maps, and other information related to the long-term surveillance program for the Green River disposal site are subject to formal and unannounced audits by the DOE UMTRA Project Office or the NRC. Specific QA criteria have already been developed for aerial photographs (DOE, 1992a).

\section{Ground water monitoring}

Ground water monitoring is required at the Green River disposal site for compliance with 52 FR 36000 (1987). The ground water monitoring program will be conducted by the UMTRA Project Office until the site is licensed. Thereafter, site monitoring under the LTSP will be conducted by the GJPO.

QA activities for ground water monitoring will describe the policy, organization, functional activities, and QA/OC protocols and SOPs needed to achieve data quality objectives (DQO) for the intended use of the data. Specifically, QA activities will do the following:

- Identify the organizations involved with ground water monitoring activities and describe their operational, field, laboratory, and QA responsibilities.

- Summarize the DQOs for ground water restoration and QA objectives for measuring data: precision, accuracy, representativeness, completeness, and comparability.

- Discuss procedures for field and laboratory analysis of environmental samples and for sample custody, handling, packaging, shipping, and documentation. Laboratory analyses of environmental samples include the following:

- Inorganic, organic, and radiometric constituents. 
- Other chemical/physical water quality parameters.

- Discuss QA in field measurements. The QA procedures for field and laboratory methods appear in applicable SOPs in the Albuquerque Operations Manual (JEG, n.d.). When an SOP has not been completed for an activity, best management practices (standard industry procedures) will be followed.

- Describe data validation, $\mathrm{QA} / \mathrm{QC}$, and data reporting, calibration frequency, and preventive maintenance procedures for field and laboratory equipment.

- Establish guidance on internal QC checks and data reduction, validation, and reporting requirements for field and laboratory environmental samples.

- Present UMTRA Project system audit procedures and technical, field, and laboratory performance audit procedures.

- Suggest field and laboratory corrective actions and procedures for corrective actions resulting from audits.

- Present QA reporting procedures, outlining reporting requirements to management.

- Describe the record-keeping system.

Disposal sites with continuing ground water restoration requirements under 52 FR 36000 (1987), ground water monitoring, or other monitoring required to comply with 40 CFR $\$ 192.02$ (1994) will remain the responsibility of the UMTRA Project Office (DOE, 1992a). If evaluative monitoring indicates a contaminant release that requires ground water restoration and/or continued monitoring, all $\mathrm{QA} / \mathrm{OC}$ procedures previously described in this text and in DOE Order 5700.6C will apply. 


\subsection{PERSONNEL HEALTH AND SAFETY}

DOE Order 5480.1B, Environmental Safety and Health Program for DOE Operations, establishes personnel health and safety procedures for all DOE operations. After a disposal site is licensed and transferred to the GJPO, it will be responsible for health and safety procedures for GJPO personnel and subcontractors. The GJPO will determine health and safety requirements for its personnel in accordance with applicable orders and federal regulations. Because the disposal cell was constructed to control radium-226 and radon-222 releases from the RRM to within regulatory standards (52 FR 36000 (1987); 40 CFR $\$ 192.02$ (a) (1994)), radiation exposure tracking and dosimetry badges will not be needed.

\subsection{HEALTH AND SAFETY}

\subsubsection{Unusual hazards and specific safety concerns}

The inill site was used to process ores and assemble rocket components. Some of the potential hazards arising from these activities include solvents, degreasers, acids, and bases. Located at the old mill site are abandoned buildings that may be structurally unsound; therefore, employees should stay clear of them as much as possible. The disposal cell does not appear to pose a significant radiological hazard; however, the disposal cell is covered with loose, jagged cobblestone, and injuries may result from slipping, falling, or tripping on the cell cover. Other possible hazards associated with the Green River disposal site include a small, intermittent stream that runs nearby; electric power lines (345 kilovolts) crossing the disposal site; possible buried utility lines; and a buried propane pipeline and tank at the mill site.

\subsubsection{Emergency medical and law enforcement}

Local emergency medical and law enforcement agencies have been briefed on the scope of work at the Green River disposal site during the long-term surveillance and maintenance phase. The following 24-hour emergency number is pertinent:
- Fire:
(801) 564-8111
- Ambulance:
(801) 564-8111 (helicopter available)
- Police/sheriff:
(801) 564-8111

The nearest hospital with an emergency room is in Moab, Utah, $60 \mathrm{mi}(100 \mathrm{~km})$ south from Green River. Green River has a clinic staffed by nurses that is located at $110 \mathrm{~S}$. Medical Street.

\subsection{REPORTABLE INCIDENTS}

The inspection team should be briefed by the GJPO health and safety officer on potential site hazards and other requirements prior to site inspections or visits. 
In accordance with DOE Order 5000.3B, any accident, injury, or environmental event (e.g., tornado, flood, etc.) occurring during the site inspection is a reportable incident. The condition or event will be reported to the GJPO facility manager or designated contact within 8 hours of the occurrence. The GJPO facility manager's 24-hour telephone number for reporting an incident is (303) 248-6070. 


\subsection{REFERENCES}

DOE (U.S. Department of Energy), 1994a. Modifications to the Remedial Action Plan and Site Design for Stabilization of the Inactive Uranium Mill Tailings Site at Green River, Utah, RAP Modification No. 2, Rev. O, July 1994, prepared by the U.S. Department of Energy, UMTRA Project Office, Albuquerque Operations Office, Albuquerque, New Mexico.

DOE (U.S. Department of Energy), 1994b. UMTRA Project Technical Assistance Contractor Quality Assurance Implementation Plan, DOE/AL/62350-72D, Rev. 0, March 1994, prepared by the U.S. Department of Energy, UMTRA Project Office, Albuquerque Operations Office, Albuquerque, New Mexico.

DOE (U.S. Department of Energy), 1993. Licensing Plan for UMTRA Project Disposal Sites, final, September 1993, DOE/AL/62350-9F, prepared by the U.S. Department of Energy, UMTRA Project Office, Albuquerque Operations Office, Albuquerque, New Mexico.

DOE (U.S. Department of Energy), 1992a. Guidance for Implementing the UMTRA Project Long-term Surveillance Program, UMTRA-DOE/AL-350125.0000, Rev. 1, prepared by the U.S. Department of Energy, UMTRA Project Office, Albuquerque Operations Office, Albuquerque, New Mexico.

DOE (U.S. Department of Energy), 1992b. Vegetation Growth Patterns on Six RockCovered UMTRA Project Disposal Cells, UMTRA-DOE/AL-400677.0000, February 1992, prepared by the U.S. Department of Energy, UMTRA Project Office, Albuquerque Operations Office, Albuquerque, New Mexico.

DOE (U.S. Department of Energy), 1992c. 1991 Annual Prelicensing Inspection of the Green River, Utah, UMTRA Project Disposal Site, DOE/ID/12584-98, prepared by the U.S. Department of Energy, UMTRA Project Office, Albuquerque Operations Office, Albuquerque, New Mexico.

DOE (U.S. Department of Energy), 1992d. Long-Term Surveillance and Maintenance Program Quality Assurance Program Plan, P-GJPO152, July 1992, prepared by Rust Geotech Inc. for the U.S. Department of Energy, DOE Grand Junction Projects Office, Grand Junction, Colorado.

DOE (U.S. Department of Energy), 1991. Remedial Action Plan and Site Conceptual Design for Stabilization of the Inactive Uranium Mill Tailings Site at Green River, Utah, UMTRA-DOE/AL-050510.GRNO, prepared by the U.S. Department of Energy, UMTRA Project Office, Albuquerque Operations Office, Albuquerque, New Mexico.

DOE (U.S. Department of Energy), 1990. Requirements for Quality Control of Analytical Data, DOE/HWP-65/R1, Hazardous Waste Remedial Actions Program/Oak Ridge Operations Office, Oak Ridge, Tennessee. 
DOE (U.S. Department of Energy), 1989. Regulatory Alternatives for Groundwater Compliance for the DOE's UMTRA Project, "Alternate Concentration Limits, Supplemental Standards, and Institutional Controls for the Department of Energy's UMTRA Project," UMTRA-DOE/AL-400659.0000, March 1989, prepared by the U.S. Department of Energy, UMTRA Project Office, Albuquerque Operations Office, Albuquerque, New Mexico.

DOE (U.S. Department of Energy), 1988. Environmental Assessment of Remedial Action at the Green River Uranium Mill Tailings Site, Green River, Utah, DOE/EA-0343, prepared by the U.S. Department of Energy, UMTRA Project Office, Albuquerque Operations Office, Albuquerque, New Mexico.

EPA (U.S. Environmental Protection Agency), 1991. Groundwater Protection Standards, SAR 1166, Document GWSTDI.WP5, Office of Radiation Programs, Washington, D.C.

EPA (U.S. Environmental Protection Agency), 1989. Statistical Analysis of Groundwater Monitoring Data at RCRA Facilities - Interim Final Guidance, EPA/530-SW-89-026, Washington, D.C.

EPA (U.S. Environmental Protection Agency), 1988a. Guidance on Remedial Actions for Contaminated Ground Water at Superfund Sites, EPA/540/G-88-003, OSWER Directive 9283.1-2, Washington, D.C.

EPA (U.S. Environmental Protection Agency), 1988b. Statement of Work for Organic Analysis, Contract Laboratory Program, Statement of Work No. 288, Washington, D.C.

EPA (U.S. Environmental Protection Agency), 1986. RCRA Groundwater Monitoring Technical Enforcement Guidance Document (TEGD), OSWER Directive 9950.1. Washington, D.C.

JEG (Jacobs Engineering Group Inc.), 1993. UMTRA Technical Assistance Contractor Quality Assurance Program Plan, DOE/AL/62350-56, Rev. 4, prepared by Jacobs Engineering Group Inc., Albuquerque, New Mexico, for the U.S. Department of Energy, UMTRA Project Office, Albuquerque Operations Office, Albuquerque, New Mexico.

JEG (Jacobs Engineering Group Inc.), n.d. Albuquerque Operations Manual, standard operating procedures, prepared by Jacobs Engineering Group Inc., Albuquerque, New Mexico, for the U.S. Department of Energy, UMTRA Project Office, Albuquerque Operations Office, Albuquerque, New Mexico.

MK-F (MK-Ferguson), 1991. Green River, Utah, Final Completion Report, prepared by MK-Ferguson for the U.S. Department of Energy, UMTRA Project Office, Albuquerque Operations Office, Albuquerque, New Mexico. 
NRC (U.S. Nuclear Regulatory Commission), 1990. Final Technical Evaluation Report for the Proposed Remedial Action at the Green River Tailings Site, Green River, Utah, Washington, D.C.

\section{DOE ORDERS}

Order 1324.2A, Records Disposition, April 9, 1992, U.S. Department of Energy, Office of Information Resources Management, Washington, D.C.

Order 5000.3B, Occurrence Reporting and Processing of Operations Information, February 22, 1993, U.S. Department of Energy, Albuquerque Operations Office, Albuquerque, New Mexico.

Order 5400.1, General Environmental Protection Program, June 29, 1990, U.S.

Department of Energy, Environmental Protection Division, Office of Environment, Safety and Health, Washington, D.C.

Order 5480.1B, Environment, Safety and Health (ES\&H) Program for DOE Operations, September 1986, U.S. Department of Energy, Safety Programs Division, Washington, D.C.

Order 5700.6C, Quality Assurance, August 21, 1991, U.S. Department of Energy, Office of Nuclear Energy and Office of Environment, Safety, and Health, Washington, D.C.

\section{FEDERAL REGISTER}

52 FR 36000, "Standards for Remedial Actions at Inactive Uranium Processing Sites; Proposed Rule," September 24, 1987.

55 FR 45591, "Custody and Long-Term Care of Uranium and Thorium Mill Tailings Disposal Sites," October 30, 1990.

\section{UNITED STATES CODE}

42 USC $\$ 7901$ et seq., Uranium Mill Tailings Radiation Control Act, November 8, 1978.

\section{U.S. CODE OF FEDERAL REGULATIONS}

10 CFR Part 40, Domestic Licensing of Source Material, U.S. Nuclear Regulatory Commission (1994).

36 CFR Parts 1220-1238, National Archives and Records, Subchapter B - Records Management, National Archives and Records Administration (1994). 
40 CFR Part 192, Health and Environmental Protection Standards for Uranium and Thorium Mill Tailings, U.S. Environmental Protection Agency (1994).

40 CFR Part 264, Standards for Owners and Operators of Hazardous Waste Treatment, Storage, and Disposal Facilities, U.S. Environmental Protection Agency (1994).

41 CFR Part 101, Federal Property Management Regulations, General Services Administration (1994). 


\subsection{LIST OF CONTRIBUTORS}

The following individuals contributed to the preparation of this LTSP.

\begin{tabular}{ll}
\hline Name & Contribution \\
\hline C. Silva & Document coordination \\
J. Senger & Site manager, document review \\
P. Martinez & Real estate specialist \\
J. Crain & Engineering, ground water hydrology \\
G. Ruskauff & Ground water hydrology \\
J. Lommler & Document review, engineering \\
A. Holm, L. Ulland & Document review \\
D. Thalley & Technical editing, document production \\
T. Gagliano, B. Harvey & coordination \\
\hline
\end{tabular}


ATTACHMENT 1

NRC CONCURRENCE AND LICENSING DOCUMENTATION 


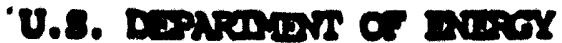

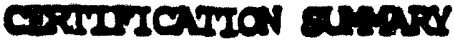 \\ 80. the \\ Cun Rive, tenn, Difoend alte}

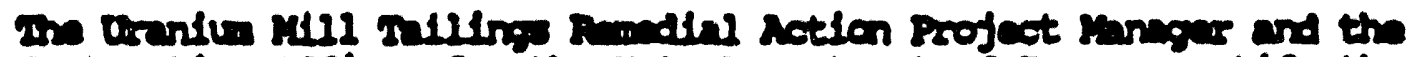

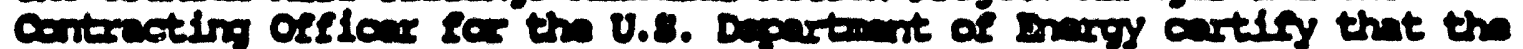

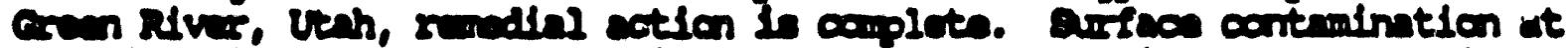
the all alte he ben placed in a dipond oull on slte. The rudin

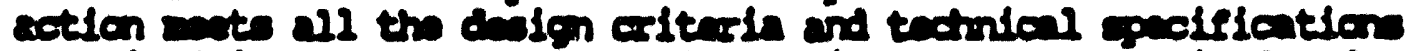

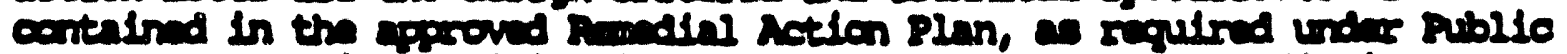

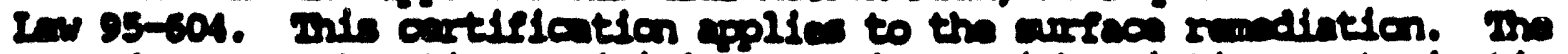

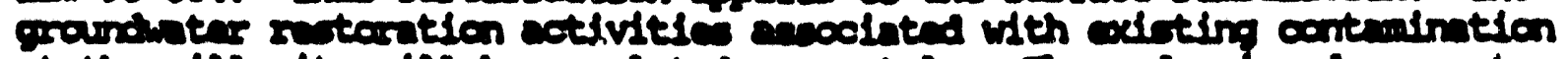
at the rill site will be completed sepretaly. In undarsignd roput that the V.8. Muclear papulatory cominsion conour in this ourtifleation.

Theleme prower

relanie J. Thoms

Contracting officar

Prograns and ReD Branch

contracts and Procurcuant Division

arre:_api/, 1982

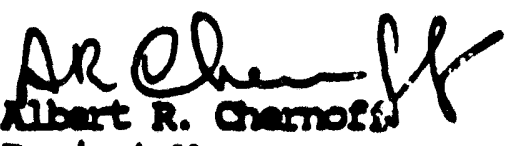

Project Manager

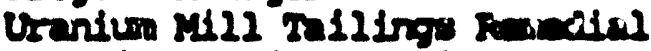

setion project offios

DrE: $\quad 3 / 23 / 92$

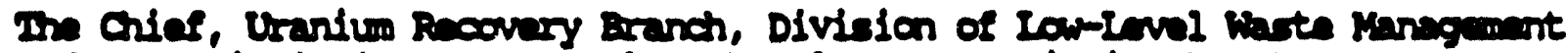
and Docomissioning, U.S. Muclear Ragulatory Cowniesion harby conors with the U.S. Departinnt of Erargy's canpletion of arface randial action at the Green Rivar, Utah, combind proconsing and dipoasl site.

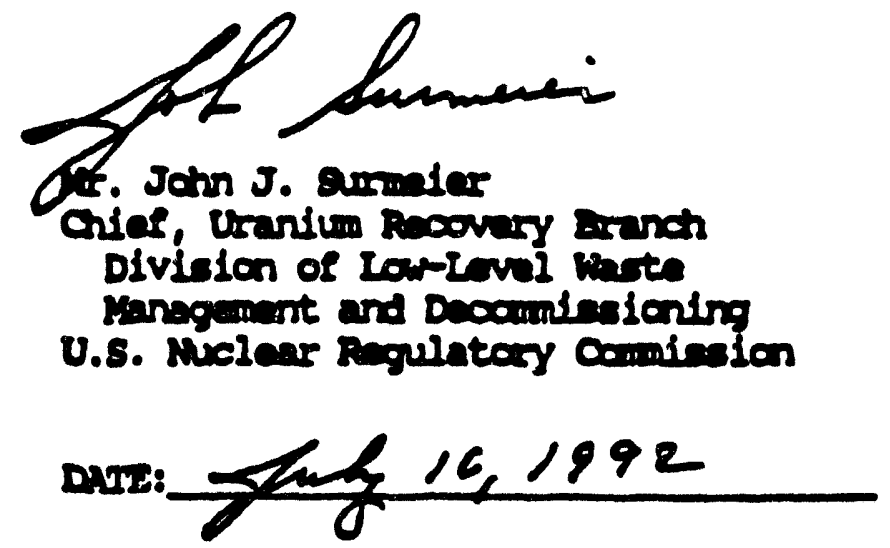


U.S. Departunt of Energy

ierocment No. OE-FCO4-8IAL16257

Appendix 8 (Remedisl Action Plan)

for ereen River, Utah

\section{SITMATURE PAAF}

THE UNITED STATES OF AERICA

DEPARTMENT OF ENERT

Dy: Trsible

Mark L. Matthows

Reting Project Manager

Urantum Mill Tallings Project office

Albuquerque operations office

P.0. Box 5400

Aibuquerque, Mow Mexico 87115

MN $22 \mathrm{MO}$

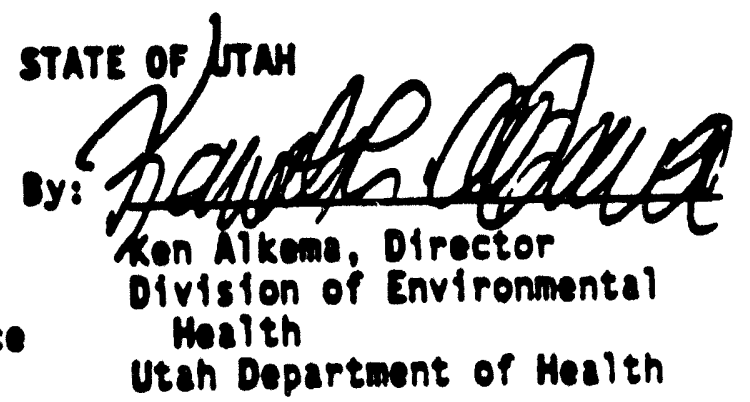

Date: $\quad$ MN 22 mo

\section{CONCURREHCE}

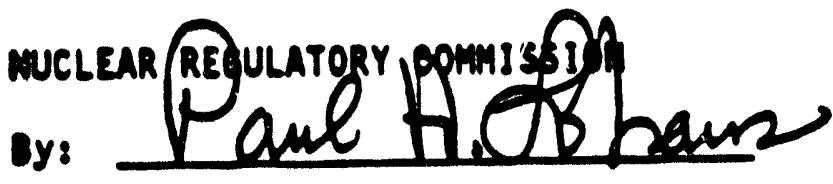

Paul H. Lohaus, Chtof

Operations Branch

Diviston of Low Level Maste

Manageanent 8 Deecuidsstoning

Date: Mreh 22, 1990

(Soe ItR transalteal letter dated Marcb 22, 1990, for condselons of concurrence) 


\section{ATTACHMENT 2}

\section{SITE OWNERSHIP/CUSTODY DOCUMENTATION}




\section{LAND OWNERSHIP DOCUMENTATION}

\section{GENERAL}

Real estate acquisition associated with the long-term surveillance program for the Green River disposal site consists of surface and subsurface rights, together with all easements and rights-of-way appearing of record. The acquisition totals 103.5 acres (ac)

[42 hectares (ha)] of land formerly owned by Umetco Minerals Corporation (Umetco). The fee simple title acquired conveys all reservations of oil, gas, and mineral rights owned or leased by Umetco. Contained within the 103.5 ac (42 ha) of state-owned land is the final disposal cell boundary. The area encompassed by the final site boundary is 21.5 ac $(8.7$ ha). This area will be conveyed by the state to the United States of America. This action has been assigned to the U.S. Army Corps of Engineers (USACE) by the DOE.

\section{DOCUMENTATION OF ACQUISITION}

A. Surface and subsurface acquisition

(1) Legal description of state-owned land

A parcel of land located in the NE corner of Section 22, Township 21 South, Range 16 East, Salt Lake Base Meridian (SLBM), Grant County, Utah, more particularly described as follows:

Beginning at a point which is $S 32^{\circ} 37^{\prime} 09^{\prime \prime} \mathrm{W} 296.82$ feet from the NE corner of Section 22 and running thence S $41^{\circ} 35^{\prime} 50^{\prime \prime} \mathrm{W} 1310.46$ feet; thence S $90^{\circ} 00^{\prime} 00^{\prime \prime} \mathrm{W} 830.00$ feet; thence N $21^{\circ} 03^{\prime} 48^{\prime \prime} \mathrm{W}$ 1585.97 feet; thence $N 22^{\circ} 54^{\prime} 21^{\prime \prime}$ E 770.78 feet; thence $N$ $77^{\circ} 45^{\prime} 28^{\prime \prime}$ E 1084.67 feet; thence S $82^{\circ} 56^{\prime} 32^{\prime \prime}$ E 1058.02 feet; thence S $9^{\circ} 27^{\prime} 44^{\prime \prime}$ E 669.10 feet; thence S $21^{\circ} 02^{\prime} 15^{\prime \prime}$ W 696.42 feet to point of beginning of this description, said parcel containing 103.5 ac, more or less, including all reservations of oil, gas and mineral rights owned or leased by Umetco Minerals Corporation appearing of record or enforceable in law and equity, together with and subject to any and all easements, restrictions, and rights of way appearing of record or enforceable law and equity.

(1a) Recorded

Book: 409, Page: 78-79, County: Grand, State: Utah, Filing date: December 8, 1988 .

(2) Legal description of final site boundary

Contained within the above described state-owned land is a parcel of land which is described as follows: Beginning at a point which is 
S $6115^{\prime} 37^{\prime \prime W}, 176.78$ feet from the northeast corner of Section 22, T21S, R16E and running thence S $422^{\prime} 00^{\prime \prime} \mathrm{W}, 1291.87$ feet; thence N $4644^{\prime} 09^{\prime \prime} W, 233.45$ feet; thence N $7627^{\prime} 51$ "W, 555.43 feet; thence North, 185.00 feet; thence N 51 27'32" $E, 377.16$ feet; thence S $7902^{\prime} 45^{\prime \prime} E, 157.88$ feet; thence $N 42$ 52'44" $E, 95.52$ feet; thence $N 158^{\prime} 30^{\prime \prime} E, 145.09$ feet; thence $N 5020^{\prime} 35^{\prime \prime}, 493.58$ feet; thence S $8234^{\prime} 07^{\prime \prime} E, 463.90$ feet; thence $S 4826^{\prime} 51$ " $E$, 293.98 feet to the point of beginning. Contains 21.5 ac $(8.7 \mathrm{ha})$ more or less.

\section{(2a) Records}

Once the USACE records the deeds, copies will be forwarded to the UMTRA Project Office for incorporation into the LTSP.

\section{TRANSFER OF FINAL DISPOSAL SITE}

Pursuant to the Cooperative Agreement between the state of Utah and the U.S.

Department of Energy, the tract described in (2) above will be transferred to the Federal Government prior to licensing of the final disposal site by the Nuclear Regulatory Agency.

Pursuant to the ground water remediation phase of UMTRA the DOE requires that access easements are obtained by the DOE for ground water activities. The easement will encumber that portion of the state-owned property in (1) that is not conveyed to the Federal Government in (2) above.

\section{REAL ESTATE FILES}

Real estate correspondence and related documents are maintained and filed by the Department of Energy, Albuquerque Operation Office, Property Management Branch, Facilities and Property Management Division, Albuquerque, New Mexico, under the supervision of Corville J. Nohava, (505) 845-6450. 
ATTACHMENT 3

GREEN RIVER PERMANENT SITE FILE INDEX 
GREEN RIVER PERMANENT SITE FILE INDEX

\section{LICENSING DOCUMENTATION}
A. Long-term surveillance plan (LTSP) (final)
B. Prelicensing custodial care
C. U.S. Nuclear Regulatory Commission acceptance of LTSP
D. General license takes effect

\section{DOCUMENTATION OF DOE TITLE/CUSTODY}

A. Documentation:

- State

- Federal

- Tribal

B. Legal description

C. Custodial care agreements

\section{NATIONAL ENVIRONMENTAL POLICY ACT (NEPA) DOCUMENTATION}
A. Environmental impact statement/environmental assessment
B. Record of decision/finding of no significant impact
C. Additional NEPA documentation
D. Mitigation action plan

\section{REMEDIAL ACTION DOCUMENTATION}
A. Disposal site characterization report
B. Remedial action plan/remedial action selection report
- Concurrence pages (signed)
C. Draft/final technical evaluation report
D. Final design for construction
E. Additional design/construction documents/drawings 
F. Final closeout inspection report

G. Site certification report/package

- U.S. Department of Energy certification/summary

- Final completion report

- Final audit report

- Completion report review

- Certification pages (signed)

\section{AS-BUILT CONSTRUCTION}

- Drawings and maps

\section{PHOTOGRAPHS}
A. Construction photographs
B. Aerial photographs
C. Closeout/inspection photographs
D. Verification and orientation/initial prelicensing inspection photographs

\section{MONITORING DOCUMENTATION}
A. Active monitoring wells
B. Location of inactive (abandoned) monitor wells
C. Monitoring station records
D. Monitoring reports
E. Programmatic procedures

\section{AGREEMENTS}
A. Interagency
B. Individual/private
UPDCC SITE FILE INDEX 


\section{ATTACHMENT 4}

\section{SITE INSPECTION PHOTO LOG}




\section{Site Inspection Photo Log}

Site:

Site Activity:

Date:

Time of Day: From

to

Weather Conditions:

Roll Number:

Film Type:

Number of Exposures:

Photo Number

Location

Description

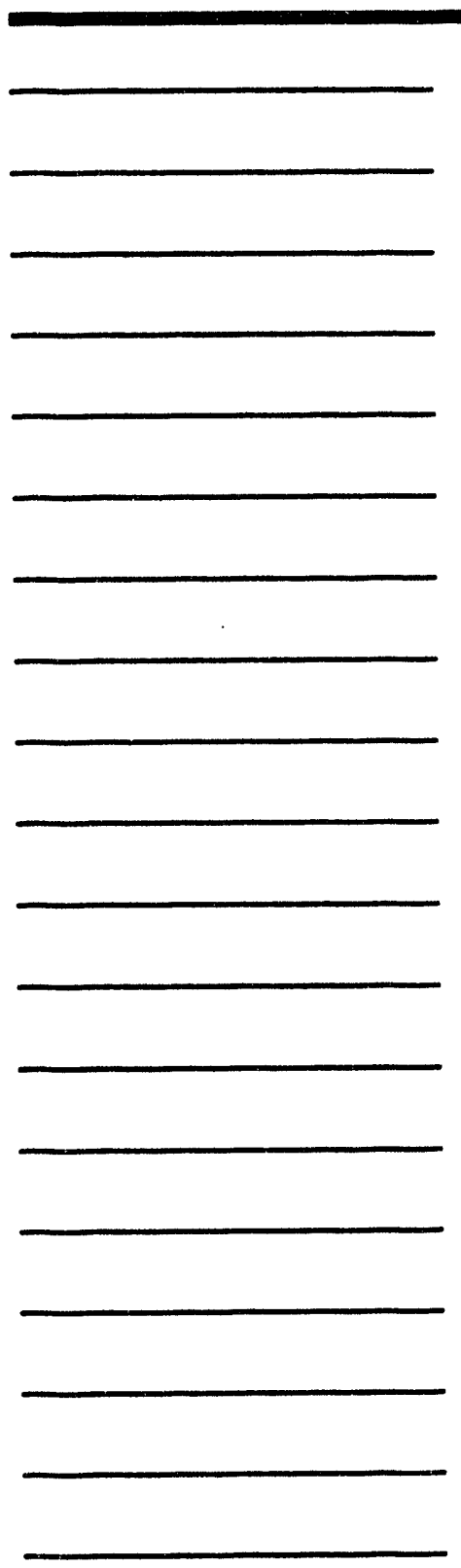


ATTACHMENT 5

INITIAL SITE INSPECTION CHECKLIST 


\section{Initial Site Inspection Checklist for the Green River, Utah, Uranium Mill Tailings Disposal Site}

Date of Last Inspection:

Reason for Last Inspection:

Responsible Agency":

Address:

Responsible Agency Official:

Inspection Start Date and Time:

Weather Conditions at Site:

Inspection Completion Date and Time:

Chief Inspector:
Name
Title
Organization

Assistant Inspector(s):

Name Title Organization

Name

Title

Organization

\section{A. GENERAL INSTRUCTIONS}

1. All checklist items must be completed and detailed comments made to document the results of the site inspection. The completed checklist is part of the field record of the inspection. Additional pages should be used as necessary to ensure that a complete record is made. Attach the additional pages and number all pages upon completion of the inspection.

2. Inspectors are to provide an up-to-date resume or vitae for inclusion in the inspection report.

3. Any checklist line item marked by an "* " that is checked by an inspector must be fully explained or an appropriate reference to previous reports provided. The purpose of this requirement is to provide a written explanation of inspector observations and the inspector's rationale for conclusions and recommendations.

*Responsibility for site inspections assigned by DOE UMTRA Project Office, Albuquerque, to DOE Grand Junction Projects Office, November 6, 1990. 
Explanations are to be placed on additional attachments and cross-referenced appropriately. Explanations, in addition to narrative, will take the form of sketches, measurements, and annotated site map overlays.

4. The site inspection is a walking inspection of the entire site, including the perimeter and sufficient transects to be able to inspect the entire surface and all features specifically described in this checklist. Every monument, site marker, sign, monitor well, and erosion control marker will be inspected.

5. A set of color print $35-\mathrm{mm}$ photographs is required. For this site, the standard set consists of photographs. In addition, all anomalous features or new features (such as changes in adjacent area land use) are to be photographed. A photo log entry will be made for each photograph taken.

6. Field notes taken to assist in completion of this checklist will become part of the inspection record. No form is specified; the field notes must be legible and in sufficient detail to enable review by succeeding inspectors and the responsible agency.

\section{B. Preparation (to be completed prior to site visit)}

1. License (includes long-term surveillance plan) reviewed.

2. Site as-built plans reviewed and base map with copies of the following site atlas overlays obtained:

a. Adjacent off-site features and land use; fences, gates, and signs; access roads and paths.

b. Survey monuments, boundary markers, site markers, aerial photo ground controls, ground photo locations.

c. Monitor wells, site drainage, diversion channels.

d. Planned inspection transects and vegetation cover.

e. Others.

These overlays will be used to identify site features and record, as appropriate, field data.

3. Previous inspection reports reviewed.

a. Were anomalies or trends in modifying processes detected on previous inspections?

b. Was a Phase II inspection conducted?

c. Was custodial maintenance performed?

d. Was contingency repair work done as a result of the Phase II inspection? 
4. Site custodial maintenance and contingency repair records reviewed.

a. Has site contingency repair resulted in a change from as-built conditions?

b. Are reviewed as-builts available that reflect contingency repair changes?

5. If required, adjacent property entry approval obtained (attach signed access agreement).

6. Aerial photos, if taken since last inspection, reviewed. For each set, enter date taken, scale, and if interpreted.

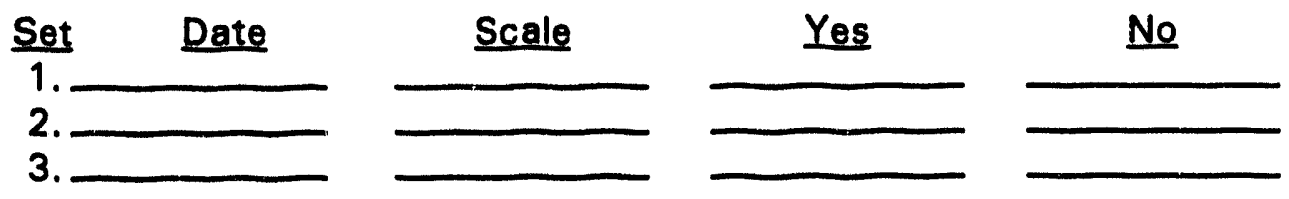

7. Were any of the following suggested by examination of aerial photographs? (If yes, give photo set date and indicate if item noted by interpreter or inspector.):
a. Intrusion by man?
b. Intrusion by animals?
c. Channelized erosion on slopes?
d. Change in area drainage?
e. Landslides?
f. Creep on slopes?
g. Obstruction of diversion channels?
h. Bank erosion of diversion channels?
i. Seepage?
j. Cracking?
k. Change in vegetative cover?
I. Displacement of fences, site markers, boundary markers, or monuments?

m. Change in adjacent land use?

n. Evidence of tailings exposure or transport? 
8. From as-builts or subsequent inspection reports, note distance and azimuth from designated site locations, such as a monument, to adjacent off-site features that could eventually affect integrity of site.

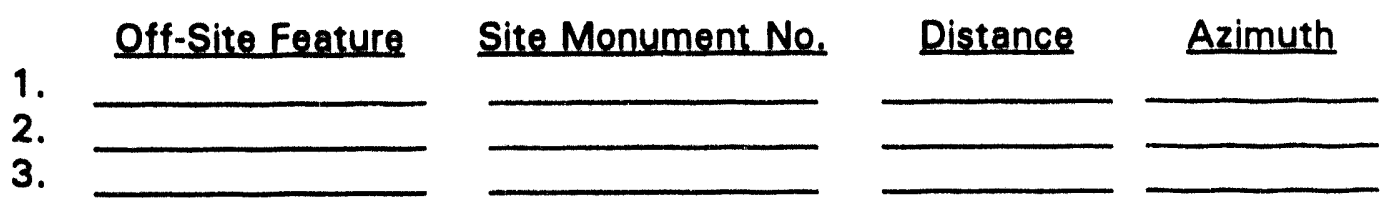

9. Assemble and check out the following equipment as needed to conduct inspections:

a. Cameras, film, and miscellaneous support equipment.

b. Binoculars.

c. Tape measure.

d. Optical ranging device.

e. Brunton compass.

f. Photo scale stick.

g. Erasable board.

h. Plant press, plastic bags for vegetation.

i. Keys to locks.

j. Bolt cutters.

k. Hand lens.

I. Clipboard.

m. Others.

C. Site Inspection

1. Adjacent off-site features (within $0.25 \mathrm{mi}[0.4 \mathrm{~km}]$ of site boundary)

a. Have there been any changes in use of adjacent areas? (grazing, construction, agriculture)

b. Are there any new roads or trails?

c. Has there Deen a change in the position of nearby stream channels?

d. Has there been headward erosion of nearby gullies?

e. Are there new drainage channels? 
f. Others?

2. Access roads and paths, fences, gates, and signs. (Section

a. Is there a break in the fence?

b. Have any posts been damaged or their anchoring weakened?

c. Is there evidence of erosion or digging beneath the fence?

d. Does the gate show evidence of tampering or damage?

e. Is there any evidence of human intrusion?

f. Is there any evidence of large animal intrusion?

g. Have any signs been damaged or removed? (Number of signs replaced:

h. Are access roads and paths passable?

i. Others?

3. Monuments and other permanent features. (Section

a. Have the survey or boundary monuments been defaced or disturbed?

b. Have the site markers been disturbed by man or natural processes?

c. Do natural processes threaten the integrity of any monument or site marker?

d. Have aerial photo ground controls been disturbed?

e. Others?

4. Crest (Section

a. Is there evidence of uneven settling? (depression, scarps)

b. Is there cracking?

c. Has the outer cover layer been breached?

d. Is there evidence of erosion?

(1) By water? (rills, rivulets)

(2) By wind? (pedestal rocks, ripple marks)

e. Is the vegetation cover as described in the as-builts?

f. Is there evidence of animals burrowing?

g. Is there evidence of riprap or gravel deterioration?

h. Others? 

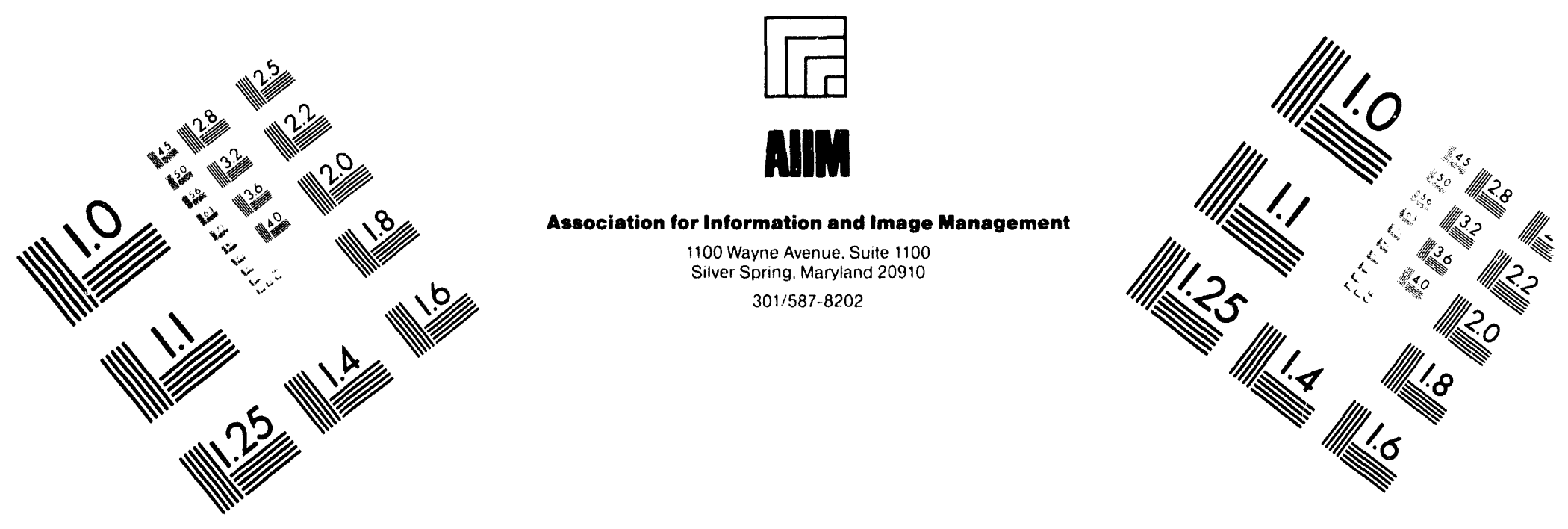

\section{Centimeter}

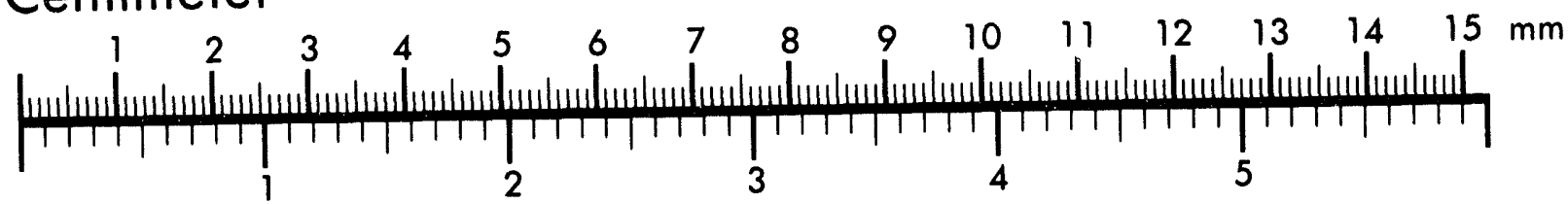
Inches
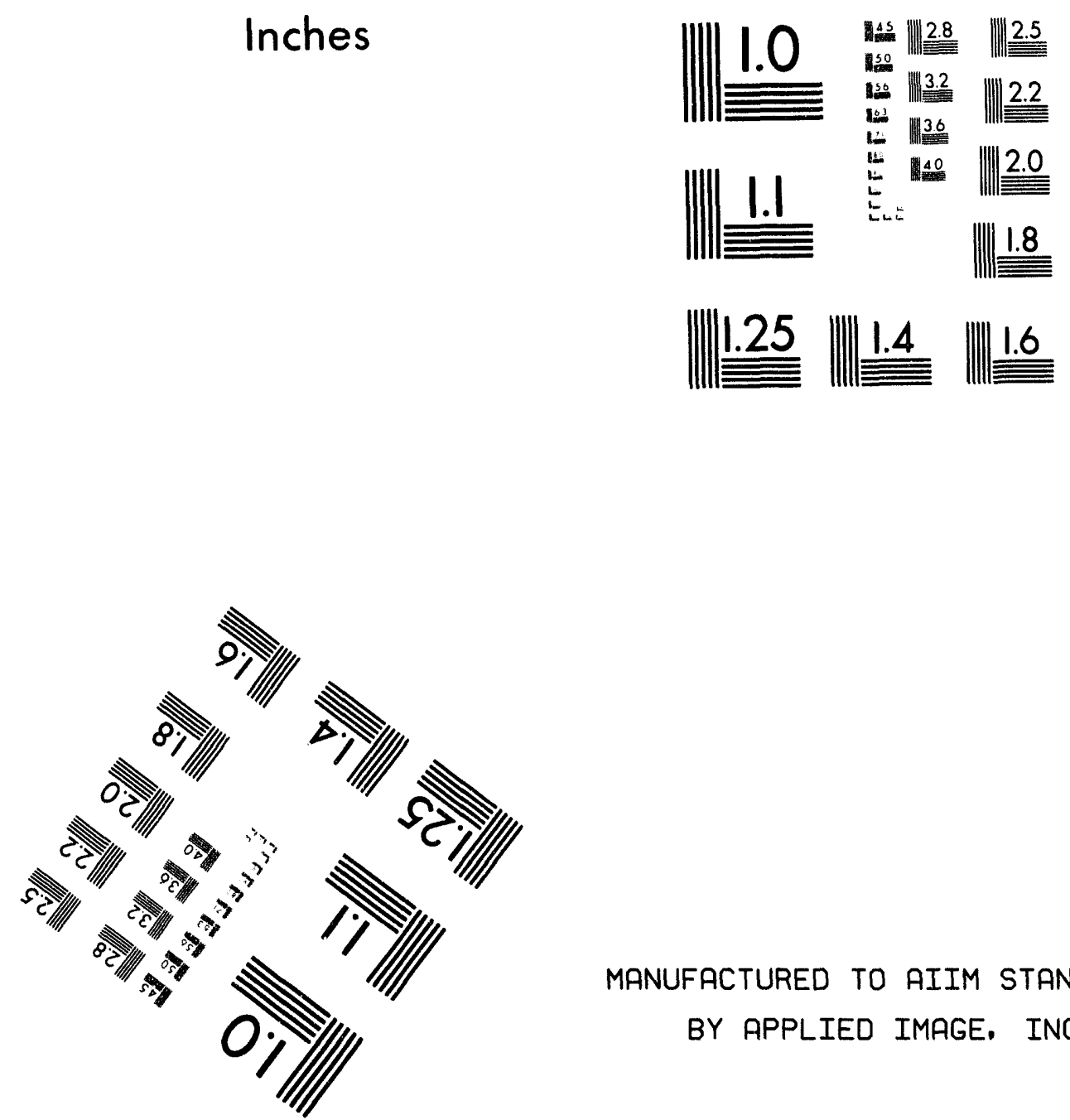

MANUFACTURED TO AIIM STANDARDS BY APPLIED IMAGE, INC.

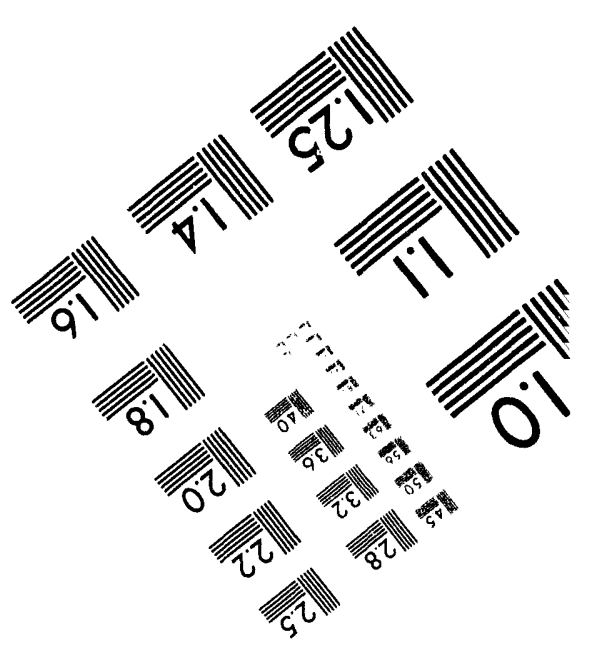



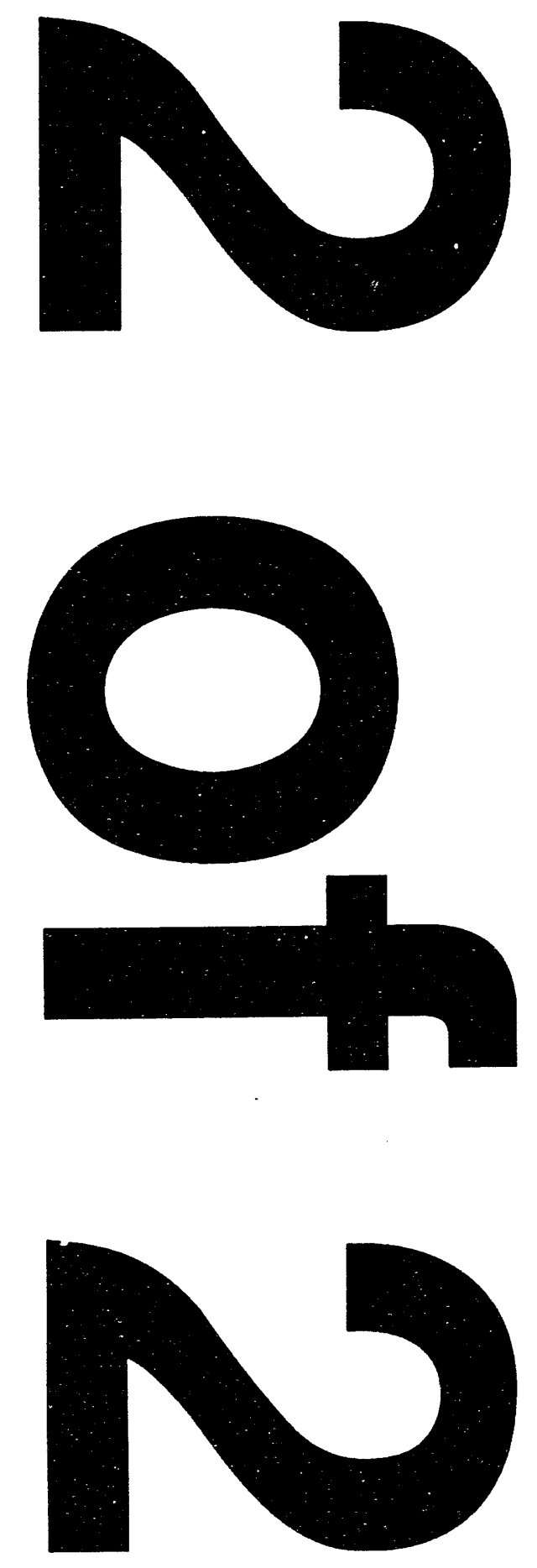
5. Slopes (Section

a. Is there evidence of gradual downslope movement (creep)? (terraces, deflection of plants)

b. Is there cracking?

c. Can depressions or bulges on the slope be seen?

d. Has the outer cover layer been breached?

e. Is there evidence of erosion?

(1) By water?

(2) By wind?

f. Has water runoff become channelized? (rivulets, gullies)

g. Is there evidence of seepage? (moisture, color, vegetation)

h. Has the vegetation cover changed significantly since the last inspection?

i. Is there evidence of animal burrowing?

j. Is there evidence of deterioration of riprap or gravel cover?

k. Others?

6. Periphery (within site boundaries) (Section

a. Is there evidence of seepage such as wet areas or localized change of vegetation?

b. Is there evidence of sediment transport from the tailings pile by water or wind?

c. Is the vegetation cover as described in the as-builts?

d. Is the drainage as described in the as-builts?

e. Others?

7. Diversion channels (Section

a. Is there evidence of bank erosion?

b. Has the integrity of riprap structures been disturbed by man or natural processes?

c. Is there evidence of channel erosion?

d. Is there evidence of sedimentation in the channel?

e. Is the vegetation pattern in the channels consistent with that shown in the as-builts?

f. Is the channel obstruc:ed in any way? 
g. Is there any evidence that the diversion channels are not performing their function?

h. Others?

8. Photography (Section

a. Have all photos required by the site atlas photo overlay been taken?

b. Has a photo log sheet been prepared for each roll of film exposed?

c. Number of rolls of film exposed:

d. Others?

9. Monitor wells (Section

a. Have any monitor wells been disturbed by man or natural processes?

b. Does any natural process threaten the integrity of any monitor well?

c. Are all monitor wells' label plates intact and legible?

d. Are all monitor wells capped and locked?

e. Others?

\section{Field Conclusions}

1. Is there an imminent hazard to the integrity of the tailings pile? (Immediate report required)

Person

Agency to whom report made:

2. Are more frequent Phase $I$ inspections required?

3. Are existing contingency repair actions satisfactory?

4. Is a Phase II inspection required?

5. Is a contingency report or custodial maintenance required?

6. Rationale for field conclusions: 


\section{E. Certification}

I have conducted a prelicensing inspection of the Green River uranium mill tailings site in accordance with the procedures of the license (includes the site surveillance and maintenance plan) as recorded on this checklist, attached sheets, field notes, photo log sheets, and photos.

Chief Inspector's Signature

Title
Printed Name

Date 
ATTACHMENT 6

AGENCY NOTIFICATION AGREEMENTS 


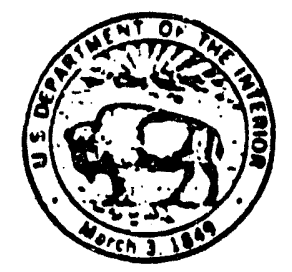

Oinenter

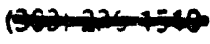

nescerts

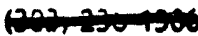

MIS/UMT/129:-0075

National Earthquake Information Center

World Data Center A for Seismology

\author{
U.S. Geological Survey \\ Box 25046, DFC, MS-967 \\ Denver, Colorado 80225 USA \\ Telex: (WUTCO) 5106014123ESL UD \\ FAX: (303) \\ $273-0450$
}

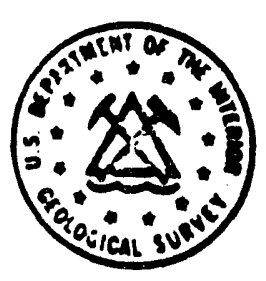

Operations

(303)- $273-8500$

QED

$(800) 358-2663$

December 14, 1992

Albert $R$. Chernofe

UMTRA Project Manager

U.S. Department of Energy

Uranium Mill Tailings Remedial Action

Project office

5301 Central Ave. NE, Suite 1720

Albuquerque, NM 87108

Dear Mr. Chernoff:

This letter is to confirm that the DOE Grand Junction Projects office has been added to our notification list for earthquakes near the following sites:

$\begin{array}{lll}\text { Green River, UT } & 39.0 \mathrm{~N} & 110.0 \mathrm{~W} \\ \text { "Spook" site, WY } & 43.2 \mathrm{~N} & 105.6 \mathrm{~W} \\ \text { Tuba City, Az } & 36.1 \mathrm{~N} & 111.1 \mathrm{~W} \\ \text { Shiprock, NY } & 36.8 \mathrm{~N} & 108.7 \mathrm{~W}\end{array}$

We have entered the following selection criteria into our notification program:

1. Any earthquake of magnitude 3.0 or greater, within 0.3 degrees (about 20 miles) of any site shown above, or

2. Any earthquake of magnitude 5.0 or greater, within 1.0 degrees (about 70 miles) of any site shown above.

Note that these criteria are slightly different than the ones you requested, but we believe that they will stili meet your needs. It was not possible to include your first criterion (any earthquake centered within a 9-mile radius of a site) for two reasons. First, this office does not work events that have magnitudes less than 2.5 on the Richter scale, unless someone has reported that the earthouake was felt. Since the Richter scale is logarithmic, earthquakes of magnitude 0 or even negative $(-1.3,-2.3$, etc) are possible, but with the station distribution we have it would not be possible for us to locate them. Second, the 9-mile radius, or about 0.1 degrees, is smaller than the location error which may occur for the preilminary locations we will be reporting to you. In fact, our preiliminary locations which will be reported to the Grand Junction Projects office will be reported only to the nearest tenth of a degree of latitude and longitude. 
For the sites shown above, we belleve that we can locate earthquakes reliably that are above a threshold of magnitude 3.0 . We also

suggest that if any of your personnel at any of these sites feel an earthquake, they should call our offlce at (303) 273-8500 and our duty geophysiclsts w111 check the event for them. Note that after normal duty hours, there is a recording on this number giving the home phone numbers of the two geophysicists on duty.

We have reduced the magnitude threshold for the last criterion from 6.2 to 5.0 and have increased the maximum radius from 40 miles to $70 \mathrm{miles}$ because large earthquakes are not point sources, but can have rupture lengths of significant size. For example, the landers, California earthquake on June 28 (magnitude 7.6) had a rupture length of more than $40 \mathrm{miles}$ and the Great Alaska earthquake of 1964 (magnitude 9.2 ) had a rupture length of about 400 miles. The location we compute for an earthquake is the hypocenter - the place where the earthquake starts. Usualiy an earthquake will rupture farther in one direction than others from the hypocenter. This means that a magnitude 8 earthquake with a hypocenter 60 miles away from one of your sites may in fact have ruptured directly through the site, depending on the orientation of the fault.

If you have any questions about these criteria, please give us a cal1.

sincerely,

Euce W. Tregrame

Bruce . Presgrave

Geophysicist 


\section{Department of Energy \\ Albuquerque Field Office \\ P.O. Box 5400 \\ Albuquerque, New Mexico 87185.5400}

Albert R. Chernoff

UMTRA Project Manager

Attention: Steve Hamp

U.S. Department of Energy

Uranium Mill Tailings Remedial Action

Project Office

5301 Central Avenue, NE, Suite 1720

Albuquerque, New Mexico 87108

Dear Mr. Chernoff:

This letter is to concur with the U.S. Department of Energy (DOE) request for notification as set forth in the DOE's letter of September 17, 1992. As requested in your letter, this office will contact the DOE's Grand Junction Projects Office at (303) 2486070 within eight hours of the issuance of a flash flood or tornado warning in either Emery or Grand County, Utah.

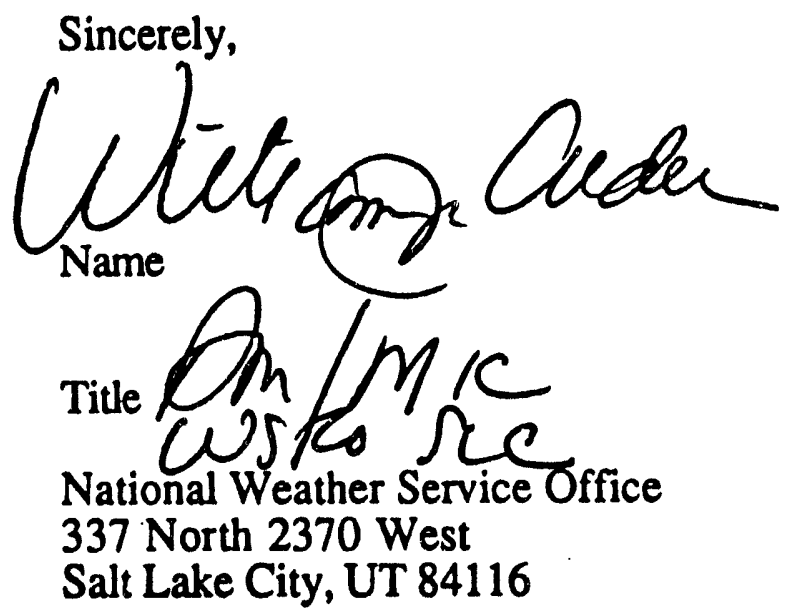

cc:

C. Jones, GJPO

J. Virgona, GJPO

F. Bosiljevac, UMTRA

S. Hamp, UMTRA

E. Artiglia, TAC 


\title{
Department of Energy
}

Albuquerque Field Otfice

P.O. Box 5400

Albuquerque, New Mexico 87185.5400

\author{
Albert R. Chernoff \\ UMTRA Project Manager \\ Attention: Steve Hamp \\ U.S. Department of Energy \\ Uranium Mill Tailings Remedial Action \\ Project Office \\ 5301 Central Avenue, NE, Suite 1720 \\ Albuquerque, New Mexico 87108
}

Dear Mr. Chernoff:

This letter is to concur with the U.S. Department of Energy (DOE) request for notification as set forth in the DOE's letter of September 17, 1992. As requested in your letter, this office will contact the DOE's Grand Junction Projects Office if any unusual event or anomaly is observed or reported at the Green River disposal site.

Sincerely,

Name: Lamar E. Guymon

Tite: Sheriff

Emery County Sheriffs Office

P.O. Box 817

Castle Dale, UT 84513

cc:
J. Virgona, GJPO
C. Jones, GJPO
F. Bosiljevac, UMTRA
S. Hamp, UMTRA
E. Artiglia, TAC 


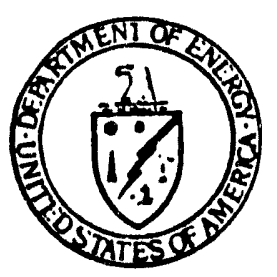

$$
\begin{gathered}
\text { MIs/UMT/029 } 3-0021 \\
\text { Department of Energy } \\
\text { Albuquerque Field Ollice } \\
\text { P.O. Box } 5400 \\
\text { Albuquerque, New Mexico } 87185.5400
\end{gathered}
$$

\section{SEP $16199 ?$}

Albert R. Chernoff

UMTRA Project Manager

Attention: Steve Hamp

U.S. Department of Energy

Uranium Mill Tailings Remedial Action

Project Office

5301 Central Avenue, NE, Suite 1720

Albuquerque, New Mexico 87108 $\therefore$

FEB 1993
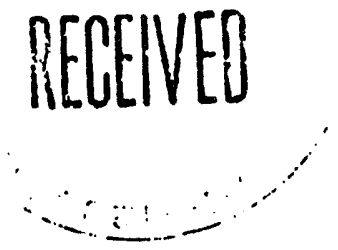

Dear Mr. Chernoff:

This letter is to concur with the U.S. Department of Energy (DOE) request for notification as set forth in the DOE's letter of Sepiember 17, 1992. As requested in your letter, this office will contact the DOE's Grand Junction Projects Orfice at (303) 2486070 if any unusual event or anomaly is observed or reported at the Green River disposal site.

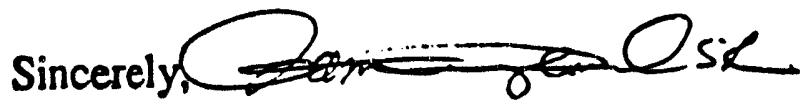

Name: JAMES D. NYLAND, SR.

Title: SHERIFF

Grand County Sheriffs Department

125 East Center Street

Moab, Utah 84532

cc:

C. Jones, GJPO

J. Virgona, GJPO

F. Bosiljevac, UMTRA

S. Hamp, UMTRA

E. Artiglia, TAC 

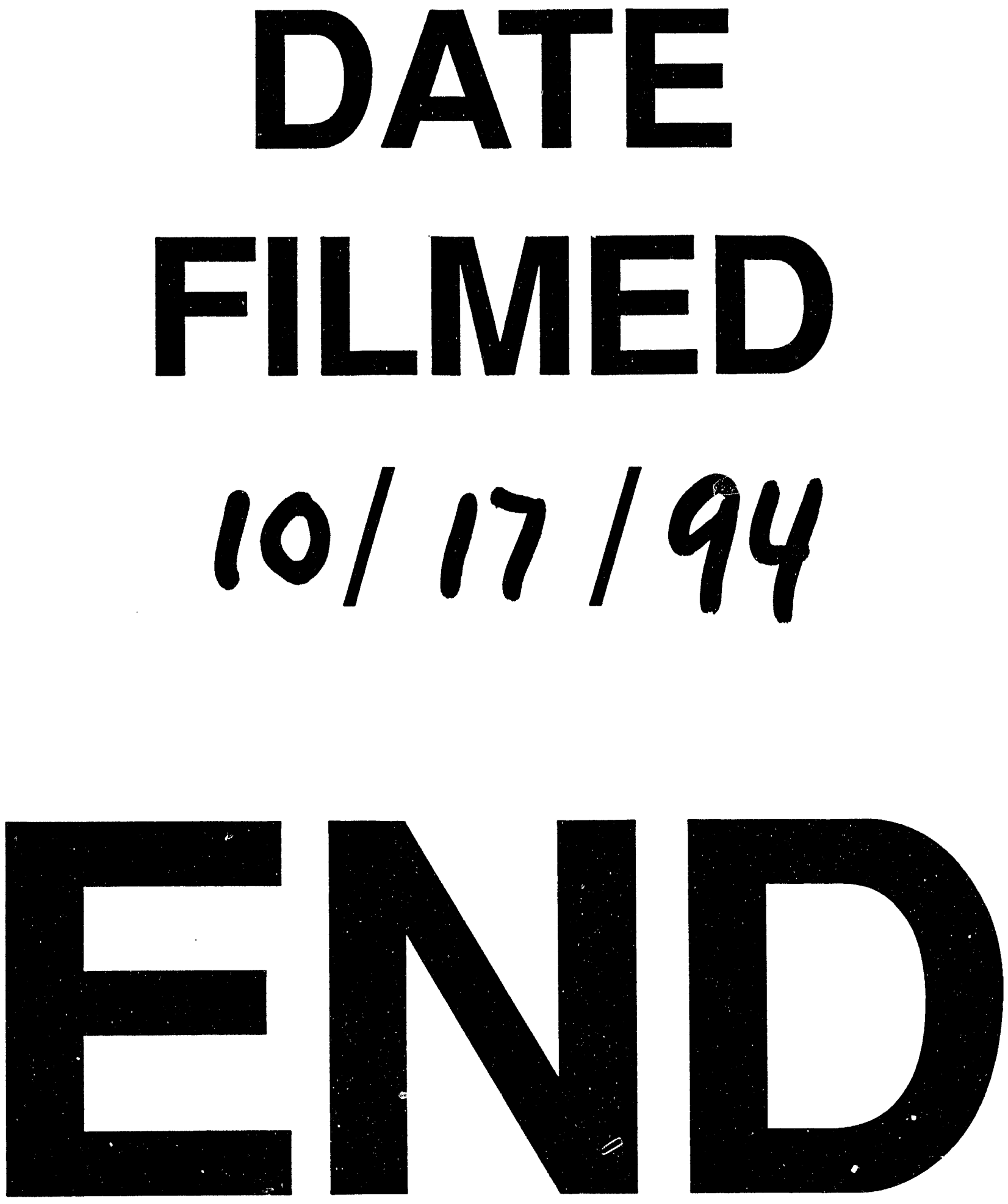
